\title{
Technical Program Plan Basalt Waste Isolation Project
}

Staff

Basalt Waste Isolation Project

December 1979

Prepared for the United States

Department of Energy

Under Contract DE-AC06-77RL01030

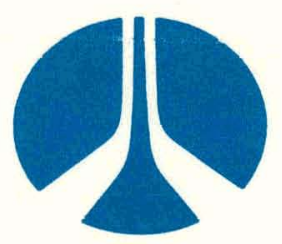

Rockwell International

Rockwell Hanford Operations

Energy Systems Group

Richland, WA 99352 


\section{DISCLAIMER}

This report was prepared as an account of work sponsored by an agency of the United States Government. Neither the United States Government nor any agency Thereof, nor any of their employees, makes any warranty, express or implied, or assumes any legal liability or responsibility for the accuracy, completeness, or usefulness of any information, apparatus, product, or process disclosed, or represents that its use would not infringe privately owned rights. Reference herein to any specific commercial product, process, or service by trade name, trademark, manufacturer, or otherwise does not necessarily constitute or imply its endorsement, recommendation, or favoring by the United States Government or any agency thereof. The views and opinions of authors expressed herein do not necessarily state or reflect those of the United States Government or any agency thereof. 


\section{DISCLAIMER}

Portions of this document may be illegible in electronic image products. Images are produced from the best available original document. 
$\cdot$

THIS DOCUMENT CLEARED

FOR PUBLIC RELEASE ON

NOVEMBER 28, 1979

\section{Rockwell Hanford Operations \\ Richland, WA 99352}

TITLE AND AUTHOR

TECHNICAL PROGRAM PLAN

BASALT WASTE ISOLATION PROJECT

Staff

Basalt Waste Isolation Project

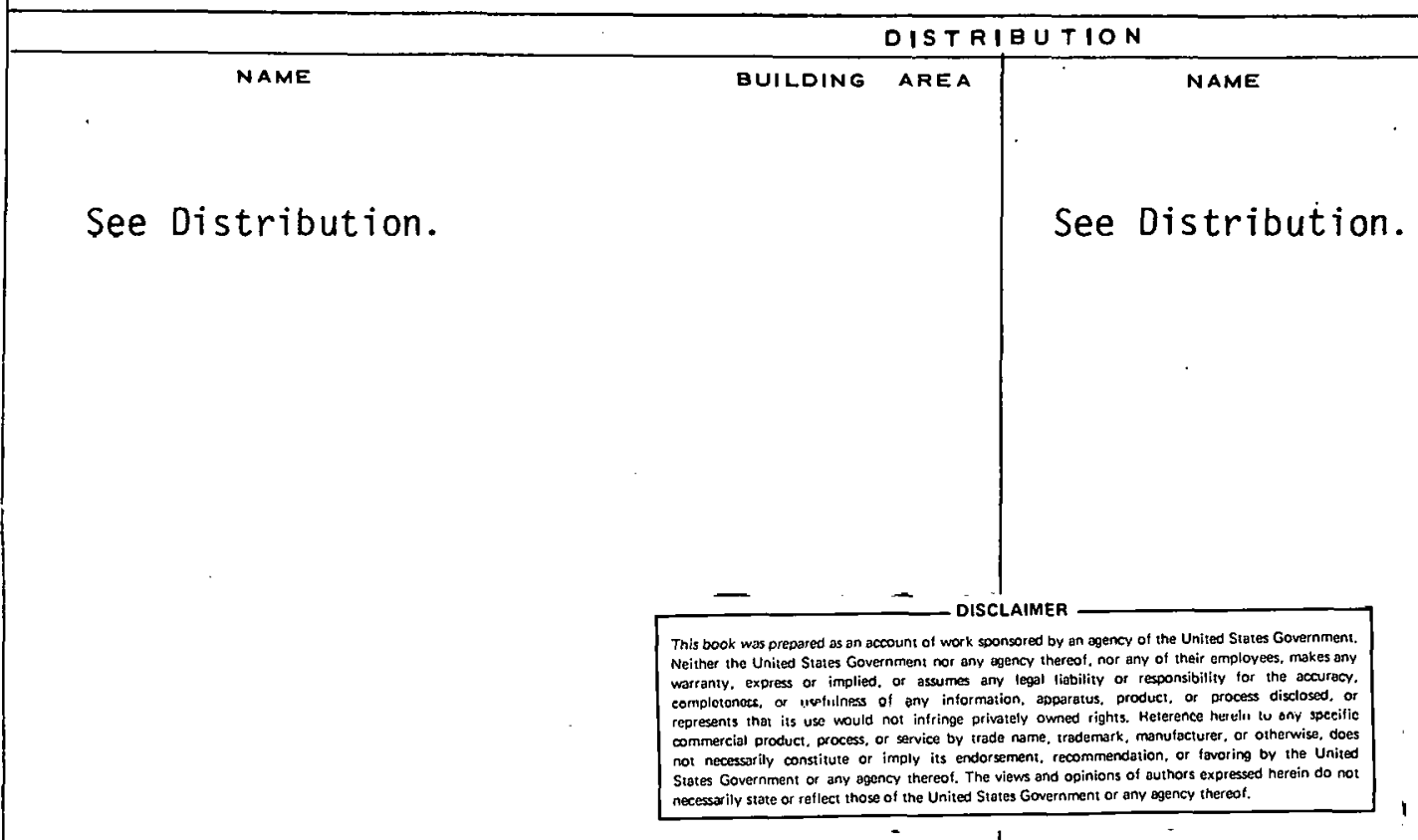

DISTRIBUTION OF THIS DOCUMENT IS UNLIMITED

ROUTE TO

PAYROLL NO.

ro
PAYROLL NO. LOCATION 
RH0-CD-132 REV 5

UNCLASSIFIED

TECHNICAL PROGRAM PLAN

BASALT WASTE ISOLATION PROJECT

Staff

Basalt Waste Isolation Project

December 1979

Prepared for the U.S. Department of Energy, by Rockwell Hanford Operations under

Contract Number DE-AC06-77RL01030

UNCLASS IFIED 
Department of Energy

Washington, D.C. 20545

December 1979

Distribution

TECHNICAL PROGRAM PLAN

BASALT WASTE ISOLATION PROTECT

This Technical Program Plan was prepared by Rockwell Hanford Operations under contract to the U.S. Department of Energy (DOE). This Plan has been approved by the Division of Waste Isolation of DOE's Office of Nuclear Waste Management for use as a basis for planning of activities to be conducted during fiscal year 1980. It is not proposed that a formal revision of this document will be made curing fiscal year 1980 although changes will be incorporated in the details of the Program as additional information is obtained. A formal revision is planned for each fiscal year.

Similar plans for work conducted by the Office of Nuclear Waste Isolation (ONWI) operated by Battelle Memorial Institute under contract to the U.S. Department of Energy and for the activities at the Nevada Test Site (NTS) are also being made available for information.
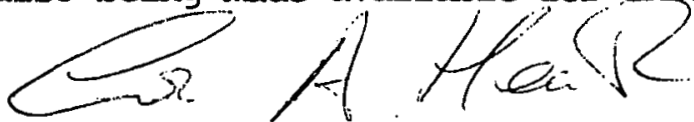

Colin A. Heath, Director

Division of Waste Isolation

office of Nuclear Waste Management 
Issue Approval:

RT Wilde

Issuing Manager $=$ R. T. Wilde

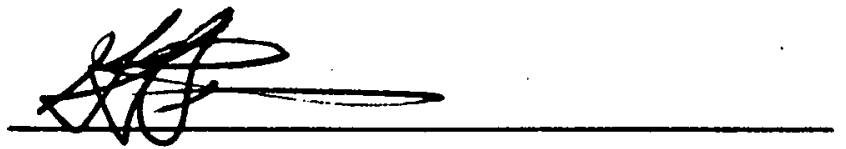

Concurring Approval - G. G. Pitts
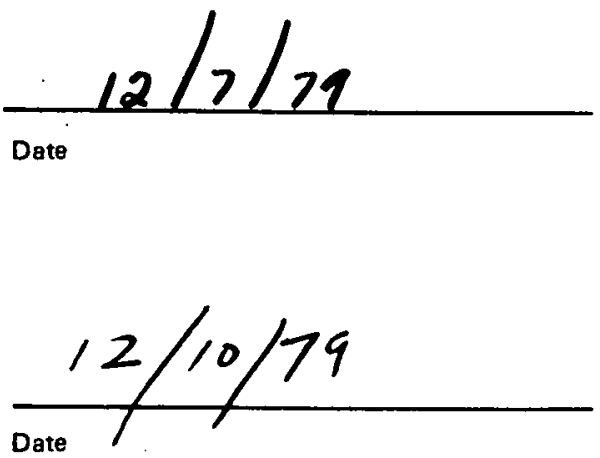

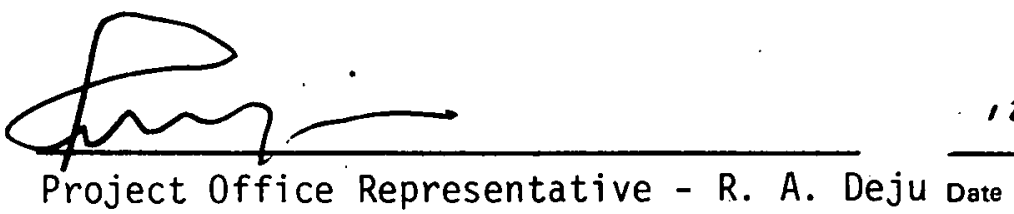




\section{CONTENTS}

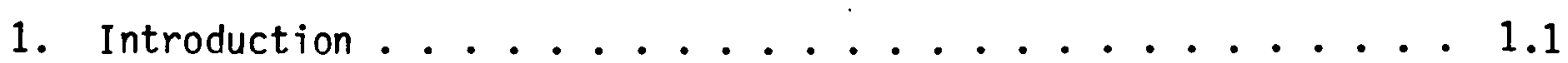

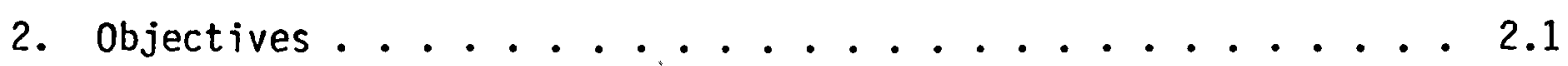

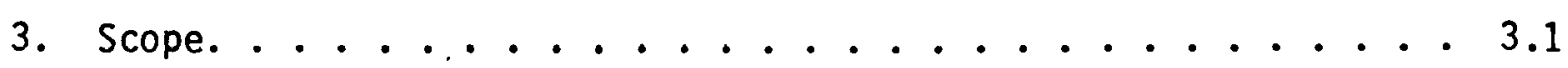

A. Program Management ............. 3.1

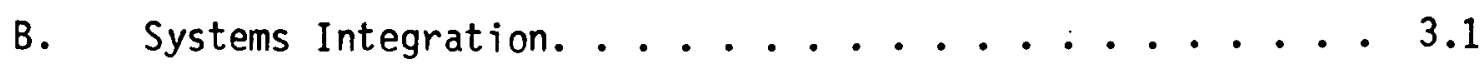

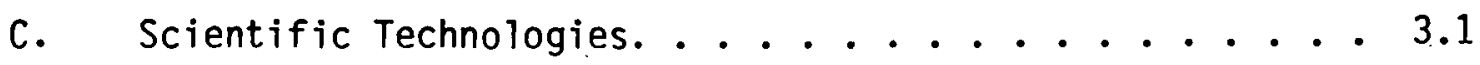

1. Geosciences. . . . . . . . . . 3,1

2. Hydrology. . . . . . . . . . . . . 3.3

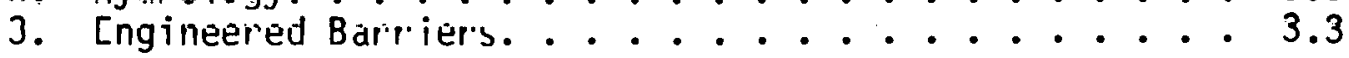

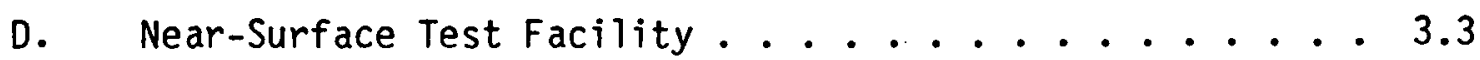

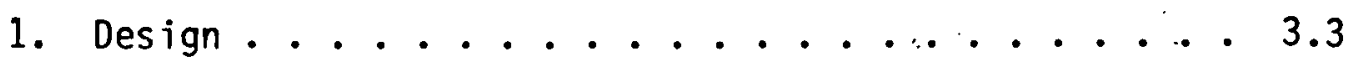

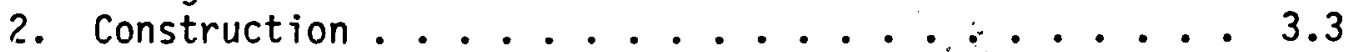

3. Engineering Testing. ............... 3

E. Repository Studies .................... 3.4

4. Program Description. ................... 4.1

A. Bases. ....................... 4.1

B. Work Breakdown Structure ............ 4.1

Projecl Management and Support - L1........ . 4.3

Project Management (L11) . . . . . . . . 4.4 4.4

Program Control (L12). . . . . . . . . 4.5

Quality Assurance (L13)........... 4.6

Material (L14) . . . . . . . . . 4.7

Uata Management $($ Lis) $\ldots \ldots \ldots$

Systems Integration $-\mathrm{L} 2 \ldots \ldots \ldots . \ldots$

Project Management (L20) . . . . . . . 4.12

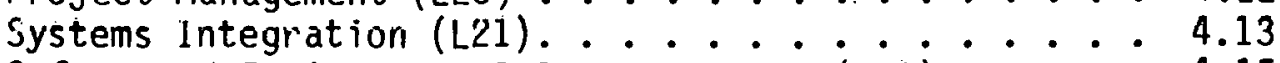

Safety and Environmental Documentation (L22) ... 4.15

Geosciences - L3 ............ 4. 4. . . .

Project Management (L30) ......... 4.20

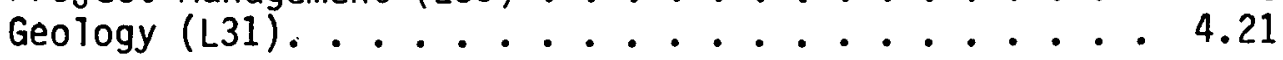


Geophysics (L32)............ 4.22

Seismic Monitoring (L33)........ 4.23

Hydrology - L4 : .. . . . . . . . . . . . . 4 4.24

Project Management (L40). ........ 4.28

Hydrology (L41) ........... 4.29

Testing Support (L42).......... 4.30

Drilling Support (L43).......... 4.31

Engineered Barriers - L5 . . . . . . . . . 4.32

Project Management (L50)......... 4.36

Multiple Barriers (L51) .......... 4.37

Borehole Plugging (L52) . . . . . . . . 4.38

Near-Surface Test Facility Design

And Construction - L6. . . . . . . . . . 4.40

Project Management (L60).......... 4.44

Design-Phase I (L61)........... 4.45

Construction-Phase I (L62). . . . . . . . 4.46

Safety and Environmental Analysis-Phase I (L63) $: 4.47$

Decommissioning-Phase I (L64) ....... 4.48

Design-Phase II (L65) . . . . . . . . . 4.49

Construction-Phase II (L66) ......... 4.50

Safety and Environmental Analys is-Phase II (L67). 4.51

Decommissioning-Phase II (L68). ....... 4.52

Engineering Testing - L7 . . . . . . . . 4.53

Project Management (L70)......... 4.58

Engineering Studies $(L 71)$......... 4.59

Phase I (L72) . . . . . . . . . . 4.60

Phase II $(L 73) . . . . . . . . . .44 .62$

Repository Studies - L8. . . . . . . . . . . 4.64

Project Management (L80).......... 4.66

Engineering Support (L81).......... 4.67

Repository Design (L82) . . . . . . . . 4.69

Long-Lead Procurement Support (L83) . . .... 4.71

Construction Manager Selection Support (L84). . 4.72

Construction (L85)........... 4.73

Site-Specific Tests (L86) . . . . . . . 4.74 
5. Schedule .......................... 5.1

A. Project Phasing Plan ................ 5.1

B. Master Project Schedule. ............ 5.1

C. End Function Operating Schedules ........ 5.1

D. Schedule Logic . . . . . . . . . . 5.1

E. Management Commitments ................. 5.1

6. Resource Requirements. . . . . . . . . . 6.1

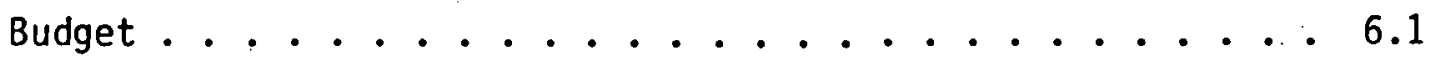

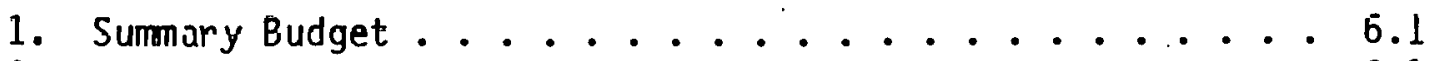

2. Expense Budget ................ 6.1

3. Capital Equipment. . . . . . . . . . . 6.1

7. Management and Control .................... 7.1

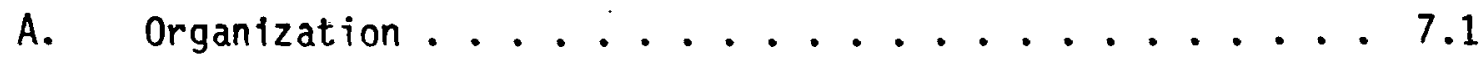

B. Role of Architect/Engineer and

Construction Manager ............... 7.1

c. Subcontractors .............. 7.5

D. Management Reviews of Individual Projects. . . . . 7.5

E. Management Reviews of cost and Schedule. ...... 7.6

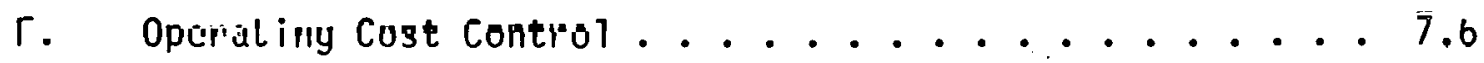

li. Capital cost Control ................... 7.6

H. Program Performance Control. . . . . . . 7.7

I. Schedule Control ............... 7.7

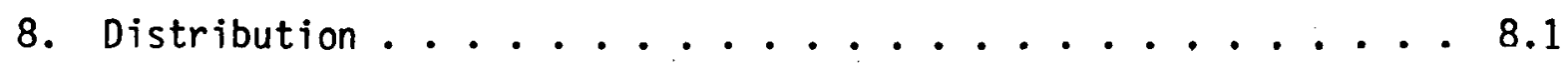

Figures:

1.1 National Waste Terminal Storage Program Organization . . . . 1.2

3.1 Siting Process--

Basalt Waste Isolation Project ............ 3.2 
4.1 Work Breakdown Structure--

Basalt Waste Isolation Project . . . . . . . . . . 4.2

4.2 Boreholes--Basalt Waste Isolation Project. . . . . . . 4 4.27

5.1 Phasing Plan--Basalt Waste Isolation Project . . . . . . 5.2

5.2 Master Project Schedule--Basalt Waste Isolation Project. . . 5.3

5.3 Overall Program Schedule--Phase Divisions. . . . . . . . 5.4

7.1 U.S. Department of Energy Project Management Organization--Basalt Waste Isolation Project . . . . . . 7.2

7.2 Rockwell Hanford Operations Organization . . . . . . . 7.3

7.3 Working Organization--Basalt Waste Isolation Project . . . . 7.4

7.4 Schedule Control Sheet--Basalt Waste Isolation Project . . . 7.8

Tables:

5.1 Major Program Milestone Description-Basalt Waste Isolation Project . . . . . . . . . 5.5

5.2 Key Milestones--Basalt Waste Isolation Project . . . . . . 5.7

6.1 Summary Budget--Basalt Waste Isolation Project . . . . . . 6.2

6.2 Expense Requirements--Basalt Waste Isolation Project . . . . 6.3

6.3 Capital Equipment Not Related To Construction--

Basalt Waste Isolation Project . . . . . . . . . . . 6.5 


\section{INTRODUCTION}

In February 1976, the U.S. Energy Research and Development Administration (currently the U.S. Department of Energy [DOE]) expanded the commercial radioactive waste management programs and established the National Waste Terminal Storage (NWTS) Program. Its mission was to provide multiple facilities in various deep geologic formations within the United States. The Office of Waste Isolation (OWI) was established within the Union Carbide Corporation-Nuclear Division to provide program management of the NWTS Program. The overal1 program consisted of investigating a number of geologic rock types to determine their suitability for terminal storage of radioactive waste. Basalts, such as the Columbia Plateau basalts which underlie a large portion of the Pacific Northwest and the Hanford Site, were selected for initial geologic reconnaissance. Atlantic Richfield Hanford Company (ARHCO) was asked in May 1976, by the OWI, to plan and execute a geologic exploration of Columbia Plateau basalts to determine the feasibility of utilizing those formations as a site for terminal storage of commercial nuclear waste.

In September 1977, the NWTS Program was restructured. The DOE assumed responsibility for the OWI program and renamed it the Office of Nuclear. Waste Isolation (ONWI). The program management was assigned to the Battelle Project Management Division. Figure 1.1 shows the relationship of the Basalt Waste Isolation Project (BWIP) as one element in the NWTS Program. While emphasis was still on a salt repository, extensive additional funds were given to support investigations of two DOE sites--Hanford and Nevada--because they are already committed to nuclear activities. The Pasco Basin, where the Hanford Site is located, also has a unique structural significance in the region; i.e., the greatest accumulation of basalt rock appears to occur within the Pasco Basin.

The BWIP is presently the responsibility of the DOE's Richland Operations Office (DOE-RL). Rockwell Hanford Operations (successor to ARHCO) is the prime contractor responsible for this work. The BWIP investigations are presently aimed at assessing the feasibility of utilizing basalts as a possible rock type for nuclear waste storage. As recently noted in a report by the Interagency Review Group (IRG) (Report to the President by the Interagency Review Group on Nuclear Waste Management, October 1978, TID-28817 [Draft]), once feasibility is established at various sites DOE will decide which site is selected for construction of a repository. The schedules presented in this technical program plan are directed toward establishing a technical basis for a site selection decision by the end of fiscal year (FY) 1981. For planning purposes, all the long-range schedules assume a favorable decision on basalt in Fy 1981. If this site selection decision is deferred to a later date, based on implementation of a different IRG strategy, all dates used in this document beyond the site selection decision would be revised accordingly. 


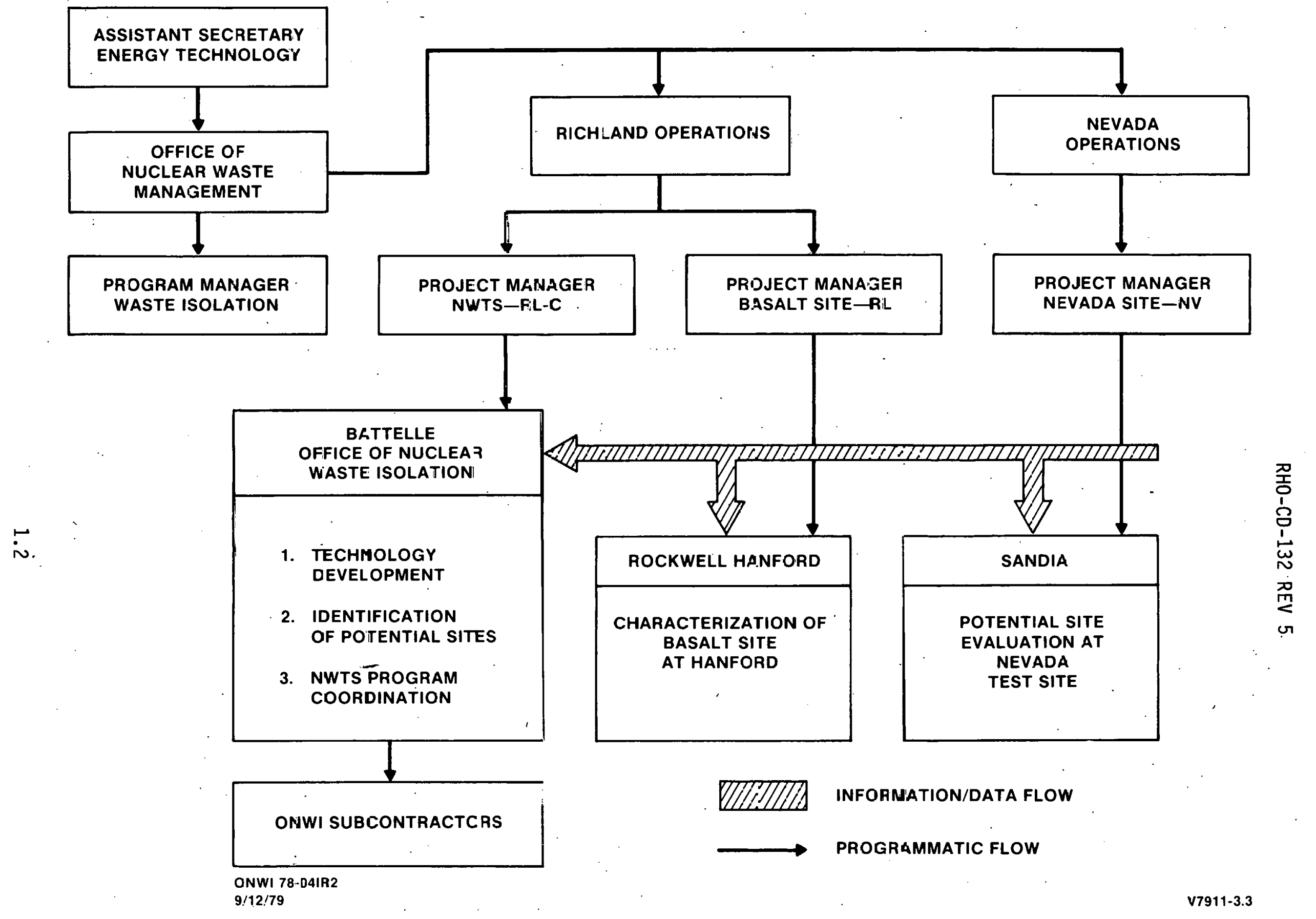

FIGURE 1.1. National Naste Terminal Storaje Program Organization. 


\section{OBJECTIVES}

The BWIP, an element of the NWTS Program, is aimed at examining the feasibility and providing the technology needed to design and construct a geologic repository for storage of radioactive waste in basalt formations beneath and within the Hanford Site. This facility will be designed to meet the federal responsibility for custody and permanent isolation of commercial radioactive waste in the United States. The project is administered by Rockwel1 International, Energy Systems Group, Rockwell Hanford Operations (Rockwel1) under contract to the DOE. Programmatic emphasis at present is in assessing site suitability by FY 1981. 


\section{SCOPE}

The BWIP covers all activities necessary to assess the feasibility and provide the technology needed to design and construct a geologic repository for storage of radioactive waste in basalt formations beneath and within the Hanford Site. To accomplish this end, the program is further divided into the following areas.

\section{A. PROGRAM MANAGEMENT}

This area includes the overall management of the program, budget, schedule and technical control activities, quality assurance, purchasing, and data management.

\section{B. SYSTEMS INTEGRATION}

The systems integration area involves the definition of studies required as part of the qualification of basalt as a repository medium for nuclear waste storage. These studies include the planning of demonstration facilities as well as the specification of scientific studies to be undertaken for and during the licensing process. Trade-off studies to analyze or optimize features are conducted to evaluate several options for accomplishing an activity. The systems integration department assures that the BWIP technical baseline documents are in accordance with the configuration management plan. In addition, the systems integration program is responsible for utilizing the results of ongoing research and development insofar as needed to identify potential repository sites in basalt and assess the feasibility of nuclear waste storage in basalt. Thus, the systems integration program is responsible for integrating all research and development studies and preparing the information needed for licensing a nuclear waste repository in basalt.

\section{SCIENTIFIC TECHNOLOGIES \\ 1. Geosciences}

The geologic studies are gathering the data required for identification and evaluation of potential repository sites in basalt. These studies will lead to identification of repository target areas, if any, that potentially provide geologic barriers adequate to prevent release of radiocontaminants to the biosphere. If a candidate repository site(s) is successfully identified, geologic studies will thoroughly characterize the area to determine the extensiveness of individual basalt flows, the stability of the region, and the presence or absence of potentialily hazardous geologic structures. If the federal government selects a final candidate site, geologic studies will thoroughly characterize the site and continue to evaluate existing risks and provide adequate information for any safety assessment of the candidate site(s) selected. The siting process is depicted in Figure 3.1 . 


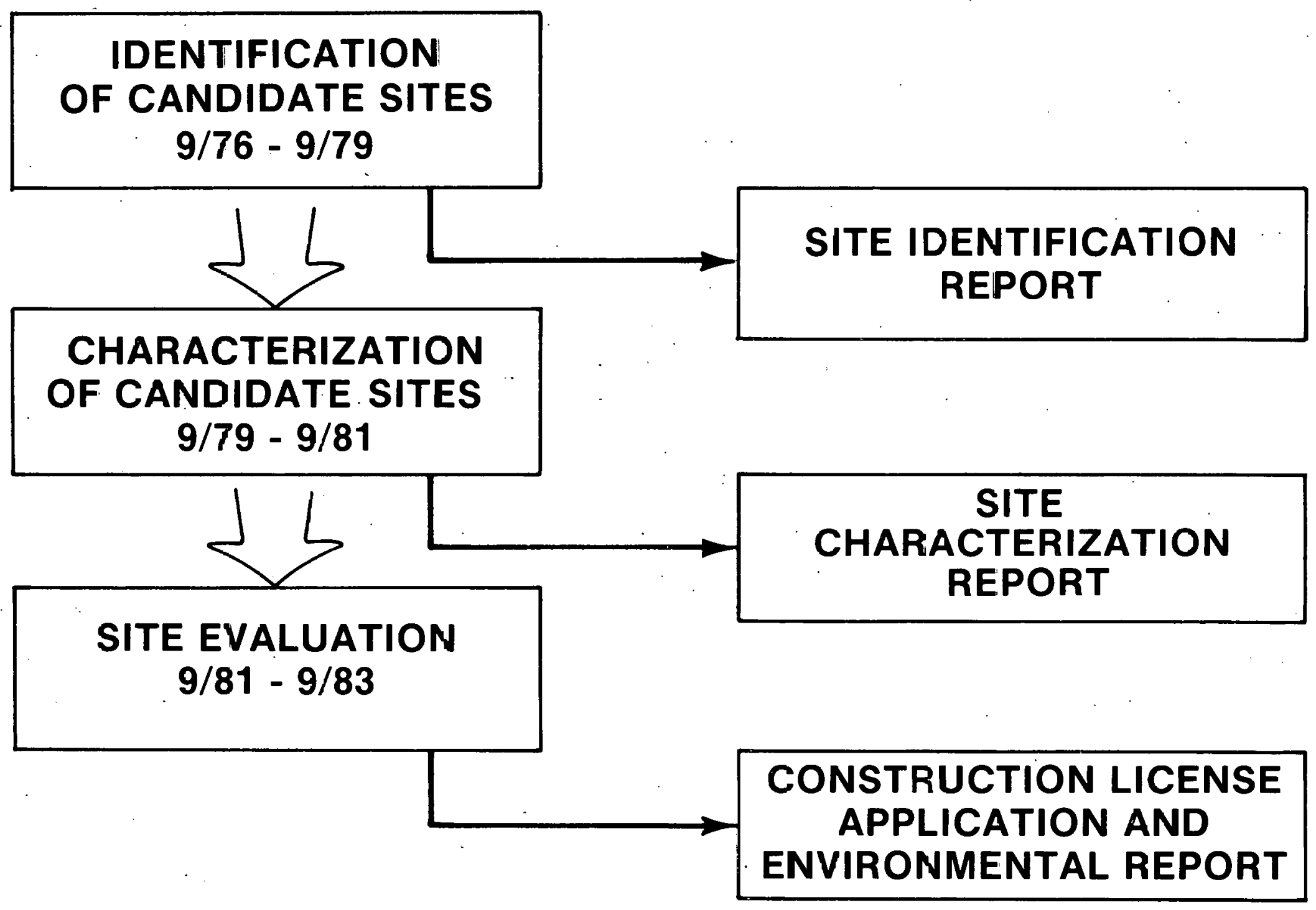

V7912-1.2

FIGURE 3.1. Siting Process--Easalt Waste Isolation Project. 


\section{Hydrology}

The hydrology program provides hydrologic criteria and evaluation techniques by which potentiai repository sites can be identified and evaluated. Studies of the ground-water regimes underlying the Columbia Plateau are important, since the ground-water pathway probably affords the most direct contact between the repository and the biosphere. Thus, hydrologic studies have emphasized the gathering of data to characterize the ground-water system underlying the Columbia Plateau and the modeling of data needed to evaluate potential radiocontaminant transport to the biosphere. Hydrologic studies include reconnaissance regional studies within the Columbia Plateau and intensive local studies within the Pasco Basin where the Hanford Site is located.

\section{Engineered Barriers}

The emplacement of nuclear waste in a geologic repository may cause physicochemical perturbations to the surrounding environment. The engineered barriers program attempts to identify, from a physicochemical standpoint, the features of various barriers to transport of radioactive contaminants. The program evaluates four potential barriers: the waste; the rock; the container; and the overpack. In addition, a borehole plugging system is being designed as a final barrier once the repository is sealed and abandoned. To assess the effectiveness of such a multiple barrier system, one examines chemical changes which could lead to chemical reactions, both at the canister (phase transformations/ dissolution) and outside the repository (dissolution/precipitation, and sorption/desorption).

\section{NEAR-SURFACE TEST FACILITY}

\section{Design}

The Near-Surface Test Facility (NSTF) is being designed as a facility for in situ examination of the behavior of an entire basalt rock mass composed of rooms embedded in the central portion of a basalt flow. These in situ tests include experiments with electric heaters, followed by experiments with spent fuel and vitrified waste where the combined effect of heat and radiation will be examined.

\section{Construction}

Approximately 3,000 feet of tunnels and test rooms are being constructed in Gable Mountain on the Hanford Site. The construction activities cover the facility construction, as well as all equipment installation for both the heater and nuclear waste tests.

\section{Engineering Testing}

A third activity related to the NSTF involves a program to provide information on the response of in situ basalt under heat loads similar to those which would be developed in a repository. In addition, the program 
will examine the in situ effect of heat and radiation resulting from the actual emplacement of nuclear waste canisters. Results from the heater tests will provide data on borehole decrepitation, thermal stability, structural integrity, temperature and displacement fields, and the influence of fractures and joints upon in situ basalt properties. These studies will provide the basis for the design of repository elements such as canister storage, borehole criteria, borehole liner performance, acceptable waste canister power levels, storage borehole array criteria, and repository step-loading evaluation. An equally important aspect of the in situ testing program is the development and verification of design models simulating the performance of a repository.

\section{E. REPOSITORY STUDIES}

The Office of Repository Studies is responsible for all work associated with the design of a nuclear waste repository in basalt. Progress to date includes completion of a repository preconceptual design report, issuance of functional design criteria for repository conceptual design, and the selection of an architect/engineer $(A / E)$ to provide repository engineering and design services. The A/E (a joint venture of Kaiser Engineers, 0akland, California and Parsons Brinckerhoff Quade \& Douglas, Inc., New York, New York) initiated work on repository conceptual design during 0ctober 1979. The repository conceptual design will provide a basis for assessing the risks and environmental impacts associated with repository construction and operation. Conceptual design will be completed by the end of FY 1981. Follow-on engineering studies will be conducted as warranted during FY 1982 to provide an adequate design basis for Title I design. In the event that the feasibility of repository construction and operation is established, and a decision is made by the federal government to proceed, Title I and Title II design work will be completed and repository construction initiated. 
RHO-CD-132 REV 5

\section{PROGRAM DESCRIPTION}

\section{A. BASES}

Pursuant to the Atomic Energy Act of 1954, as amended, the Energy Reorganization Act of 1974, as amended, and the Department of Energy Organization Act, the DOE is assigned the reponsibility for the development and operation of facilities for the long-term storage and disposal of radioactive waste arising from DOE facilities and high-level radioactive wastes arising from commercial facilities. The DOE-RL was requested in FY $1976(\$ 139,000)$ by OWI, Union Carbide Corporation-Nuclear Division, to document information and data collected during the late 1960 's and early 1970's regarding site characterization of the Hanford basalts. This work continued in FY $1977(\$ 3,200,000)$ under the direction and guidance of OWI. In FY 1978, $\$ 15,300,000$ was spent as part of this project, although independent from OWI. Establishment of the BWIP in Richland, Washington was authorized in FY 1978. Rockwell was selected as the prime contractor for the BWIP by DOE-RL.

Funds totaling $\$ 30,000,000$ were authorized in FY 1979 to continue the tasks which were initiated in FY 1978. A budget outlay totaling $\$ 44,150,000$ is planned for FY 1980 .

\section{B. WORK BREAKDOWN STRUCTURE}

The BWIP will plan, technically direct, budget, authorize, and control work for this program through a Work Breakdown Structure (WBS). A WBS identifies the major elements of the project and the components supporting each element. For purposes of management planning and control, the WBS permits the division of large work items into successively smaller, more manageable components. Further, the WBS provides a common framework for communications, graphically portrays the project, depicts how various items of work are related to the project objectives, and defines an orderly breakdown of a program to cost accumulation levels which permits effective planning and management of the work to be performed.

This BWIP plan is written at Level 3 of the WBS. Figure 4.1 provides the summary WBS to "subactivity" level. Descriptions of individual end functions and activities are contained in the following pages. 


\begin{tabular}{|c|c|c|c|c|}
\hline PROJECT & ¿No Funct!un & ACTIVITY & subactivity & weS LIMC \\
\hline \multirow{4}{*}{ PROJEECT MANAGGMENT } & \multirow{4}{*}{ 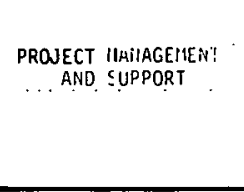 } & PRROJECT IARAAGEMENT & PROJECT HANAGEMENi & 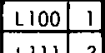 \\
\hline & & 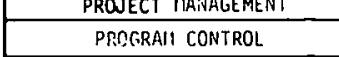 & 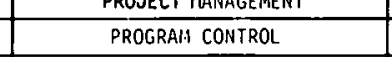 & $\begin{array}{ll}(11121 & 2 \\
\end{array}$ \\
\hline & & $\begin{array}{l}\text { UUALITY ASSUPANCE } \\
\text { ORSA }\end{array}$ & QUAL ITY ASSURANCE & 4131 \\
\hline & & $\frac{\text { MATERRIAL }}{\text { DATA NAABGGENTT }}$ & UATERIAL & L141] \\
\hline \multirow{6}{*}{ SYSTEEIS INIEGGPAT ION } & \multirow{6}{*}{ SYSTEES :WEGGATION } & 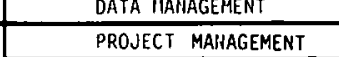 & $\begin{array}{l}\text { DATA HANAGEGENT } \\
\text { PROJECT MANAGEEENT }\end{array}$ & $\frac{1151}{1200}$ \\
\hline & & SYSTEUS MTTERAATOK & TECHNICAL CW IERIA & $\angle 211$ \\
\hline & & SYSTERS IIIEGRATIOA & SYSFEHIS ANO TEST ANALYSIS & L212 \\
\hline & & & $\begin{array}{l}\text { SiTE EVALUATION } \\
\text { ENGINERPING MOOEL DEVELOPMENT }\end{array}$ & L2713100 \\
\hline & & & 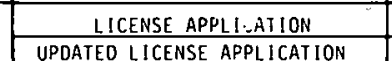 & $\frac{122112}{1222113}$ \\
\hline & & DOCUIENTATION & $\begin{array}{l}\text { ENVIROMMENTAL REPORT } \\
\end{array}$ & $\frac{122213}{122314}$ \\
\hline & GEOSC FNCES & PROJECT MANGGEMENT & PROJECT MANAGEMENT & 13000 \\
\hline & 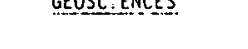 & GEOLOGY & GEOLOGY & \\
\hline & & 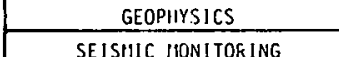 & GEDPYYSIICS & \begin{tabular}{|c|c|}
32110 \\
\end{tabular} \\
\hline & & $\frac{\text { SE ISHIIC HONI IORIING }}{\text { PROSECT MANAGEENT }}$ & 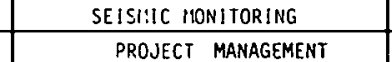 & 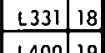 \\
\hline 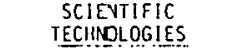 & IYOROLOCGY & HYOROLOGY & HYOROLOGY & 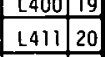 \\
\hline & & IESTING SUPPORT & $\begin{array}{ll}\text { HYOROLOGY } \\
\text { GERHYYSGS }\end{array}$ & L4212 21 \\
\hline & & & $\begin{array}{l}\text { GEOPHSYICS } \\
\text { SPECIFIF HOLES }\end{array}$ & 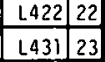 \\
\hline & & DRILLING SUPPORT & DRILLING TECHNDLOGY & L432 24 \\
\hline & & PROJECT MANAGEMENT & PRJJECT MANAGEMENT & $\llcorner 500] 25$ \\
\hline & ENGINERRED BARRI ERS & & CHARACTERIZZATION & $\mid 511] 26$ \\
\hline & 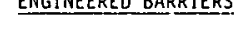 & HULTIPLE BARRIERS & EIIPLACEIENT ENV IRONMENT & 5512227 \\
\hline & & & 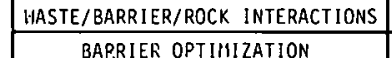 & $\mid 551328$ \\
\hline & & & 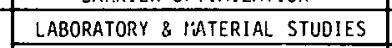 & 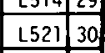 \\
\hline & & ROREHOLE FiUGG ING & 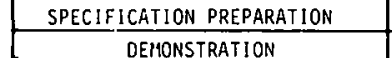 & 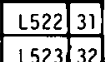 \\
\hline & & PROJECT MANGGEMENT & PROJECT MANGGEEENT & $1600 / 33$ \\
\hline & & & \begin{tabular}{|l|l|l|l|} 
ENGR STUOY \& CONCEPTUAL DESIGN \\
GEOLOGIC SURVEILLANCE
\end{tabular} & $\begin{array}{ll}6010 & 34 \\
6011 & 35 \\
\end{array}$ \\
\hline & & & $\begin{array}{l}\text { OESSIGN, TITLE I (VITRO) } \\
\text { OSGISU }\end{array}$ & $\begin{array}{lll}2612 & 36 \\
7\end{array}$ \\
\hline & & 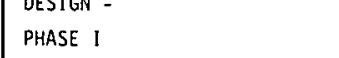 & \begin{tabular}{|l} 
DESIGN, IITLE I (ROCKWELL) \\
OESIGN, IITLE II (VITRO) \\
\end{tabular} & 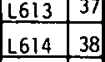 \\
\hline & & & DESLIN, TITLE II (ROCKKELL) & $\begin{array}{l}1615 \\
39 \\
\end{array}$ \\
\hline & & & | & 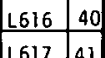 \\
\hline & & & PROCUREMENT & $1620 \quad 472$ \\
\hline & & & TUNNELS AND EXCAVATION & 662143 \\
\hline & & CONSTRUCTION. & TEST AND INSTRUHENT HOLES & 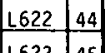 \\
\hline & & PHASE 1 & ELECT. DIST. LINE (ROCKWELL) & 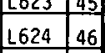 \\
\hline & NSTFE TESTISN & & EACILITY REQUIREMENTS \& SITE WORK & $2625 \cdot 47$ \\
\hline & AND CONSTRUCIION & & $\mid \begin{array}{l}\text { LAATRLLINE } \\
\text { TIILE III }\end{array}$ & 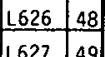 \\
\hline & & & CONSTRUCT ION MANAGEENENT & 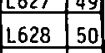 \\
\hline & & $\begin{array}{l}\text { SAEETY AND ENVI ROMMENTAL } \\
\text { ANALYSSIS - PAASE } 1\end{array}$ & \begin{tabular}{|l} 
ENVI RONMENTAL REVIEW \\
SEFTY PFICW
\end{tabular} & L631 51 \\
\hline & & DECOMMISSI IOHING - PHASE I & DECOMMISSIONING & 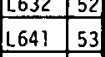 \\
\hline & & & ENGR STUOY 8 CONCEPTUAL DESIGN & 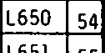 \\
\hline & & & $\mid \frac{\text { GEELOGIC SUUVEELLAACE }}{\text { DESTGN, IITLE I (YITRO) }}$ & $\begin{array}{ll}6651 & 55 \\
1652 & 55 \\
5\end{array}$ \\
\hline & & DESIGN - & \begin{tabular}{|l:l} 
DESSGN, TIITLE I (ROCKNELLL) \\
\end{tabular} & $\begin{array}{lll}6653 & 57 \\
67 & 20 \\
\end{array}$ \\
\hline & & PHASE II & 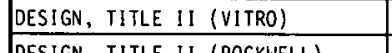 & 665458 \\
\hline & & & DESIGN, IITLE II (ROCKNELL) & 665559 \\
\hline & & & 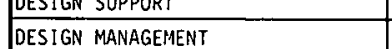 & $\begin{array}{ll}1656 & 60 \\
1657 & 60 \\
0\end{array}$ \\
\hline $\begin{array}{l}\text { NEAR-SURRACE } \\
\text { NEATE }\end{array}$ & & & PROCUREMENT & $1660 \quad 602$ \\
\hline & & & TUNNELS AND EXCAVATION & 166163 \\
\hline & & CONSTRUCtion - & \begin{tabular}{|l|l|} 
TEST AND INSTRUMENT HOLES \\
\end{tabular} & 166264 \\
\hline & & PHASE II & FACILIIY REQUIREMENTS \& SITE WORK & 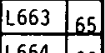 \\
\hline & & & \begin{tabular}{|l} 
BOTTOH LOAD. TRANSP. (CONTRACT) \\
\end{tabular} & 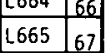 \\
\hline & & & CONSTRUCTLON MANAGGHENT & \begin{tabular}{|l|l|l|l|l|l|l|l|l|}
665 & 68 \\
\end{tabular} \\
\hline & & & & \\
\hline & & 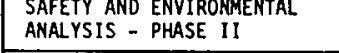 & 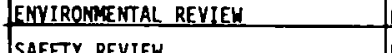 & (6.67) 70 \\
\hline & & DECOMMISS IONING - PHASE II & 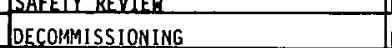 & 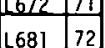 \\
\hline & & PROJECT MAAAGERENT & $\begin{array}{l}\text { PROJECT RANGGERENT } \\
\text { PRE }\end{array}$ & 470073 \\
\hline & & $\begin{array}{l}\text { ENGIMERRING } \\
\text { STIUISS }\end{array}$ & ROCK ENGINEERING & 12711 \\
\hline & & PHASE I & $\begin{array}{l}\text { LPECAILL STUDIIIS } \\
\text { HEATESS AND CONTROLERS }\end{array}$ & 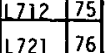 \\
\hline & & & ROCK IIISTRUAGENTATION & 1722777 \\
\hline & & & DATA ACQUISIIIION SYSTFM & \begin{tabular}{l|l}
1723 & 78 \\
\end{tabular} \\
\hline & & & SITE CHARACIERIZATIOH & 172479 \\
\hline & ENGINERING IESTING & & TEST ENGIMEERRG SUPPORT & 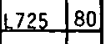 \\
\hline & & & $\begin{array}{l}\text { EOUPPMEST INSTALLATION } \\
\text { DOERATION }\end{array}$ & 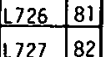 \\
\hline & & PHASE UT & $\begin{array}{l}\text { GEATERS AMD CONTROLLERS } \\
\end{array}$ & \begin{tabular}{|l|l|l|l|l|l}
1231 & 83 \\
\end{tabular} \\
\hline & & & ROCK IMSTRUMENTATION & 1232284 \\
\hline & & & DATA ADQUISII ION SYSTEE & 1733 85: \\
\hline & & & 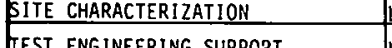 & 1734: 86 \\
\hline & & & 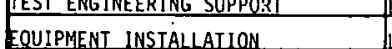 & 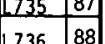 \\
\hline & & & PPERATION & 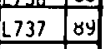 \\
\hline & & PROJECT MANAGEMENT & $\begin{array}{l}\text { PPENT FUEL PREPARATION } \\
\text { PROJECT MANAGEMENT }\end{array}$ & 1,738 990| \\
\hline & & SMC & $\begin{array}{c}\text { PROJECT MANGGEMENT } \\
\text { FUNCT IONAL DESIGN CRITERIA } \\
\end{array}$ & 1811921 \\
\hline & & ENGINERRING SUPPORT & $\begin{array}{c}\text { A/E SELECTION SUPPORT } \\
\text { SEFCAO STIDIIS }\end{array}$ & 1812929 \\
\hline & & & 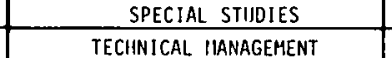 & 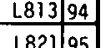 \\
\hline REPO:ITORY & REPOSI TORY & 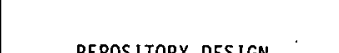 & SYSTEHS & 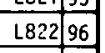 \\
\hline & & REPOSITORY DESIGN & REHOTE HANOLLNG & L823]97 \\
\hline & & & $\begin{array}{l}\text { SURFACE FACILITIES } \\
\text { SHRSTHEF }\end{array}$ & 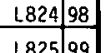 \\
\hline & & & 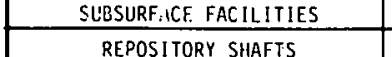 & L825999 \\
\hline & & LONG LEAO PROCÜRMENT SUPPOR & $\begin{array}{l}\text { RAPOSII ORRS SHAFT TS } \\
\text { LONG LEAD PROCURENENT SUPPORT }\end{array}$ & $\frac{1826100}{1831601}$ \\
\hline & & C/M SELECTION. SUPPORT & C/II SLLECTION SUPPORT & L84h 102 \\
\hline & & & TeClrical taragenent & L851) 03 \\
\hline & & CONSTRUCTION & SYSTEFIS & L8527604 \\
\hline & & & SUZFACE FACILITIES & L853궁 \\
\hline & & & SUBJ̈LRFACE FACIL ITIES & $\angle 854 \mathrm{~h}$ \\
\hline & & & REHOTE HANOL ING & L855toot \\
\hline & & & REPOSITORY SHAFIS & 1856608 \\
\hline & & SITE SPECIFIF, TESTS & SITE SPECIFIC TESTS & L861) 109 \\
\hline
\end{tabular}


PROJECT MANAGEMENT AND SUPPORT - LI

The objective of Project Management and Support is to plan, implement, direct, and administer all activities required to effectively control the cost, schedule, and work scope of the BWIP.

The support to Project Management encompasses cost control, quality control, scheduling, subcontracts and materials, and data management which are generic in nature.

The Project Management and Support end function includes the following five activities:

1. Project Management;

2. Program Control;

3. Quality Assurance;

4. Material;

5. Data Management.

Major Accomplishments in FY 1979

A technical information meeting was held in November 1978 to inform the public of the progress and plans of the BWIP. The technical program plan, quality assurance plan, and the FY 1980 subcontract procurement plan were updated and issued. In addition, a project management plan was prepared which identifies the specific policies and procedures necessary to effectively manage the BWIP. These policies and procedures were prepared and are operating.

\section{Major Expected Results in FY 1980}

A technical information meeting will be held in December 1980 . The technical program plan and quality assurance plan will be updated. The FY 1981 procurement plan will be developed. The BWIP project control system will be fully implemented. 


\section{OBJECTIVE}

Plan, organize staff, direct, and control combined efforts of BWIP and supporting organizations to achieve the BWIP objectives.

\section{DESCRIPTION}

Project direction and control is exercised by Project Management through defining project requirements and objectives in terms of project plans, budgets, schedules and through performance evaluation and reporting, including implementation of corrective action where appropriate. Project Management is governed by Rockwell policies.

The following are the major functions of Project Management.

- Ihe BWIP approves and gives guidance to all BWIP managers and project representatives.

- The BWIP receives, reviews, and approves all reports and correspondence relating to the project.

- The BWIP approves and presents all reports and briefings; emphasis is placed on assessments of performance, schedule, technical, and financial evaluation.

- The BWIP is the primary point of contact with DOE on all matters concerning the program.

In addition, this activity covers the information dissemination function as exercised by the BWIP specialist within the Communications and Public Affairs Department. 
ACTIVITY Program Control ACCOUNT CODE

\section{OBJECTIVE}

Develop and administer program planning, budgeting, scheduling and reporting policies, administrative systems and practices for the project. DESCRIPTION

The following are the major activities of Program Control.

- Coordinate the planning and budgeting activities for the project including the preparation of the annual operating and capital budgets, long-range plans, goals and objectives, and special reports and studies as required. Assist in the preparation and maintenance of the technical program plan that defines technical requirements and objectives, establishes schedule requirements, identifies resources, and serves as the basis for monitoring and analyzing status and performance.

- Assist in the preparation and negotiation of the work packages, which define work to be accomplished for each subactivity by functional organization, the schedules and milestones that are to be met, and the resources that are allocated.

- Develop the base line financial plan and related cost structure for the project, and analyze cost and schedule performance and variances from that pian.

- Maintain the base line budget and schedule system that defines the work required to achieve program goals and the anticipated costs of work performance and materials, contracts and major items procurement.

- Administer change control procedures to ensure that all changes to base line plans, schedules, and budgets are controlled and documented with appropriate management and customer concurrence. 


\section{OBJECTIVE}

Provide quality assurance support for the BWIP to implement a quality assurance program which will meet licensing requirements. This support. is applicable to management, site evaluation, design, procurement, and construction activities.

\section{DESCRIPTION}

The major functions of this activity are as follows.

- Participate in independent third-party design reviews to assure that requirements involving nuclear effects and consideration of electrical, mechanical, thermal, hydraulir., safety, productivity, reliability, maintainability, interfaces, engineeriny standards, design practices, and intended applications are complete and correct.

- Provide review and approval of procurement documentation to assure that complete quality requirements are stated, and that all necessary design basis technical information is included. Procurement documentation must also identify those records that must be retained and controlled by Rockwell.

- Assure that policies and procedures and instruction documents are prepared to cover 2.11 activities affecting the quality of the end product.

- Verify that control of documentation and retention of quality records is defined and controlled.

- Evaluate the capability of each supplier of materials, components, systems or services to assure acceptable products or servlces. The index of qualified suppliers will be used when possible.

- Assure identification and control of materials, parts, and components, and establish traceability of items by maintaining an appropriate documentation through the quality assurance release stages.

- Provide source and receiving inspection.

- Provide project surveillance which will include review and witnessiny of specific contractor activities to assure compliance with design specifications.

- Provide a corrective action system to correct conditions resulting in nonconforming materials, parts, comiponents, and other deviations.

- Audit policies, procedures, and instruction documents to verify compliance. 


\section{OBJECTIVE}

Material is responsible for providing materials, equipment, suppliers and services, and for controlling any changes with respect thereto for the project.

The Material activity includes the selection of sources, obtaining quotations, determining types of contracts, awarding of purchase orders and subcontractors, determining the delivery information follow-up to ensure timely delivery, and firm control of all changes in specifications or other procurement requirements.

\section{DESCRIPTION}

The major functions of the activity are as follows:

- Procure and administer subcontracts, materials, and equipment required for the BWIP.

- Maintain an updated long-range procurement plan in support of the project.

- Receive and inspect all materials and equipment purchased by the project.

- Provide shipping services for offsite shipments of material and equipment.

- Provide rate quotations, routing instructions, and transportation costs analysis. Trace and expedite inbound and outbound shipments, and order equipment for offsite shipments. 


\section{OBJECTIVE}

Establish data/configuration management system for the BWIP.

\section{DESCRIPTION}

This activity consists of the following functions.

- Issuance and control of all operating procedures covering technical aspects of the project.

- Provide engineering release and records control to assure that all new and revised documents comply with requirements contained in applicable procedures.

- Provide an engineering data management system which ensures that all documents are controlled, and controlled prints of released engineering documents are current and complete.

- Provide a control and retrieval system for all technical and reference documents. This system will be controlled by system and category identifiers for accessibility and retrieval and to provide traceability for the BWIP.

- Provide a permanent data storage system which meets the requirements of Title 10, Code of Federal Regulations (CFR) and applicable sections of the Nuclear Regulatory Commission (NRC) Regulatory Guides for storage and handling of data.

- Provide a change management system which includes review, evaluation, and approval of proposed engineering changes.

- Provide a design review system which conducts reviews of design disclosure documents for approval and implementation.

- Provide a permanent storage repository for all core samples and supporting data which meets the requirements of Title 10, CFR and applicable sections of the NRC Regulatory Guides.

- Provide a procurement data management system which includes the requirements to ensure that the required data are purchased, delivered, and maintained in a permanent storage repository for accessibility and retrieval. 


\section{SYSTEMS INTEGRATION - L2}

The objective of Systems Integration is to integrate all activities which could be required for the identification, qualification, and licensing of a site and a repository for nuclear waste within Columbia Plateau basalt. The scope of work includes review of test planning, providing computer models, trade studies, data analyses and interpretation, and establishing the technical bases and criteria for site selection, licensing, and the design of the repository and ancillary facilities and functions.

The program is divided into three activities:

1. Project Management;

2. Systems Integration;

3. Safety and Environmental Documentation.

Each of these activities is further divided into subactivities as noted in Figure 4.1 .

The Project Management activity is concerned with controlling costs and schedules, and providing technical management of the Systems Integration end function, specifically in preparing schedules, work packages, and overall guidance of other functional activities.

The Systems Integration activity is responsible for trade-off studies, integration of activities, generation of technical and systems criteria, development of engineering models, identification, evaluation, and qualification of sites, analyses and evaluation of tests and site data, and system trade studies.

The Safety and Environmental Documentation activity is responsible for preparation of environmental reports (ERs) and license applications (LAS).

Research and design activities will be reviewed, both internal and external to Rockwell, to assure application of a comprehensive, complete, and integrated technical and systems approach to the design and development of a basalt repository within the Hanford Site.

\section{Major Accomplishments in FY 1979}

Preconceptual design guidelines and the first issue of the technical criteria for the repository were issued. The methodology for screening and selecting a repository site was developed and the initial screening of prospective sites completed. These preliminary sites were identified and ranked by Rockwe 11 in preparation for presentation to DOE. The results of preliminary computer code development and modeling for the NSTF-Phase I and Phase II tests predictive results were issued. Preparation of a Site Characterization Report (SCR) was started for submittal to DOE in FY 1981 which will document the site selection procedures as described in draft 10 CFR 60. The SCR will describe the site characterization program and will be supported by appendices in the format of environmental and safety analys is reports. 
Systems Integration - L2 (continued)

\section{Major Expected Results in FY 1980}

The BWIP will be reviewed periodically by the Systems Integration staff to assure integration of design management and geoscience data, and to assure that the design criteria and the geoscience data meet the technical requirements for repository design and site qualification. Technical reports will be reviewed and recommendations made regarding how various reports and obtained data meet the technical requirements. Coordination with the ONWI will be maintained to assure the integration of the program efforts. Supporting trade studies will be conducted as needed.

Available geological, hydrological, geophysical, chemical, thermomechanical, and other data pertaining to identification of a site for a repository for nuclear waste and spent fuel will be analyzed and compared to provide the basis for identifying a repository site on the Hanford Site. Areas where additional information is required will be identified and recommendations made regarding how to obtain the needed information. A report describing the application of the technical and economic data to site evaluation and an analysis of these data will be prepared. This report will indicate how each of three sites previously selected meets the screening criteria for site identification. The effort will be directed at identifying a final, suitable site for recommendation to DOE in FY 81.

The numerical modeling activities in FY 1980 will primarily involve the application and documentation of a set of existing codes. Emphasis will be placed on defining a reference model set and developing change control procedures to control and document future changes to codes. Predictions of the thermal, mechanical, and stress behavior of basalt under the conditions of the NSTF tests will. be made and a report issued late in the fiscal year. Work initiated in FY 1979 to develop test procedure guidelines for the NSTF tests will be continued and extended to include analysis and evaluation of test results obtained during the contract period. A series of studies will be done to address questions arising in the conceptual design phase of the development of a deep repository and support will be provided to assist in the preparation of the SCR.

The executive summary section of the SCR will be prepared to meet the requirements of 10 CFR 60.11 . The final format and content of this section will be developed early in the year and the writing of the section will follow.

During FY 1980, it is planned that all of the risk assessment models will be exercised to provide early indications of any problem areas and additional data needs. This effort will use the preconceptual repository design, and will result in SCR input before the end of FY 1980, to assist basalt project planning. This is followed in FY 1981 with an analys is applied to the conceptual design. 
Systems Integration - L2 (continued)

The far-field and long-term radioactive dose to man will be estimated using the Waste Isolation Safety Assessment Program (WISAP) with input from the BWIP. The WISAP output will be compared to the results of long-term risk assessment being conducted by a BWIP subcontractor and the programs integrated to obtain a valid estimate of the risk to man.

A.11 chapters of the environmental section of the SCR will have first drafts prepared in accordance with the outline contained in 0 . J. Carrell and G. L. Jones, Apri\} 12, 1979, Proposed Format and Content of Environmental Reports for Deep Geologic Terminal Repositories for Radioactive Material, RHO-BWI-CD-18 REV 1. Land use patterns for the Columbia Plateau will be identified to aid in the determination of potential environmental effects.

A cost benefit study will also be conducted to determine the optimum way of establishing criteria for environmental and occupational exposure to radioactive materials. This study will analyze the effects that changes in the criteria have as a function of both costs and potential benefits. The study will assess the use of a probability expression as a form of presenting environmental and occupational exposure criteria.

The environmental issues required to comply with the National Environmental Policy Act will be identified and a program defined to assure that the issues are satisfied. Publications, regulations, and the BWIP requirements will be reviewed and analyzed in order to prepare a document which will summarize the environmental issues regarding the storage of high-level nuclear materials in the basalts of the Columbia Plateau. 


\section{OBJECTIVE}

The objective of Project Management is to direct the planning for the Systems Integration end function and its activities and to provide authority to the functional groups to perform those activities, and to assure that the end function objectives are met.

\section{DESCRIPTION}

This activity covers several tasks which are performed by the Systems Integration Manager.

- Preparing and maintaining the plan(s) that defines project requirements and objectives, establishing schedules, identifying resources, and serving as the basis for monitoring and analyzing slatus and performance.

- Preparing and negotiating with functional organizations work packages which define by "End Function" and "Activity" the work to be accomplished by each functional organization and schedules that are to be met, and the resources that are available.

- Monitoring and evaluating the work accomplished by each functional organization and defining corrective actions which are required to accomplish work package requirements.

- Reporting status, performance assessment, and corrective actions to the BWIP Director using standard Executive Control Meeting formats where feasible. 


\section{OBJECTIVE}

The objective of Systems Integration is to integrate all activities which could be required for identification, qualification, and licensing of a site and a repository for nuclear waste within the Columbia Plateau. The scope of work includes review of research test and design activities, providing computer models, trade studies, data analyses and interpretation, and establishing the technical bases and criteria for site identification, licensing, and the design of the repository and ancillary facilities and functions.

\section{DESCR IPTION}

Systems Integration has been divided into the following subactivities for administrative purposes as follows.

- Technical Criteria

Technical criteria shall be developed as necessary to support testing, site identification, site evaluation, repository design, systems performance, safety, environmental, and licensing activities.

\section{- Systems and Test Analys is}

This subactivity includes systems integration, trade-off studies, analysis, and evaluation efforts. Test data shall be analyzed and the results applied to the development of technical criteria, site identification, evaluation, and qualification methods, the ER and the LA.

This effort includes the review of supporting research and design activities to assure a congruent and complete approach to accomplish site selection, verify isolation, and meet safety, environmental, and licensing requirements.

Test data from the NSTF and testing support programs of the scientific technologies shall be analyzed and applied to criteria development and site selection.

The systems integration shall include survey of non-Rockwell waste isolation program data and an evaluation of their application. Some of the many activities requiring integration include risk analys is, transportation, canister design, and site selection. of specific interest are related activities by ONWI, Pacific Northwest Laboratory (PNL), Waste Isolation Pilot Plant, NRC, and DOE. 
- Engineering Model Development

Engineering model development activities resulting in new or modified computer codes shall be documented. Model change control procedures shall be developed for the documented models. Codes to be documented include Analytical and Numerical Models (Finite Element, Finite Difference and Boundary Element techniques) intended for thermomechanical analysis on the canister scale, room scale, and regional scale. A more detailed discussion of the models is provided in M. R. Hardy and G. Hocking, October 1, 1979, Numerical Modeling of Rock Stresses within a Basaltic Nuclear Waste Repository - Final

Report.

\section{- Siting Evaluation}

This task includes three phases: site identification; site characterization; and, sitc cvaluation.

In the first phase, siting criteria will be developed, areas that have a high probability of meeting the established criteria will be identified, and a method of decision analysis for selecting candidate sites will be developed. Key area characteristics will be formulated by assembling geoscientific and meteorological data, surface feature information, and any other information suitable for modeling a repository for areas under consideration. Site identification will lead to a site identification report which will be used to initiate the characterization of preferred sites. After these sites are characterized, a Site Characterization Report will be prepared in accordance with 10 CFR 60 to establish the final candidate site evaluation plan. The site evaluation phase will be completed upon submission of the license application and all its supplements. 


\section{OBJECTIVE}

The objective of this activity is to provide safety analys is and environmental reports for the repository in support of a decision to proceed with a repository in basalt.

\section{DESCR IPTION}

A SCR will be prepared by September 1981 to support a site selection decision and substantiate the site characterization information gathered in support of site selection. A safety analys is based on the repository preconceptual design will be included as part of the SCR.

The LA and the ER will be prepared concurrently. The LA will be based on NRC Regulatory Guides such as Regulatory Guide 3.26, NRC 10 CFR 50, and NRC 10 CFR 60.

The ER will be formulated following regulatory Guide 4.2 with supplementary information from Regulatory Guides 3.15 and 3.24.

Data used to prepare both the LA and the ER will come from geologic site studies, repository site studies, engineering studies such as preconceptual design and special studies, the repository conceptual design, and testing program. Test data will include borehole plugging studies, multiple barrier studies, and in situ tests from the NSTF. The long term risk assessment of the deep repository as described in the LA will be based on a risk assessment program being conducted by Los Alamos Technical Associates (LATA) and PNL.

Risk assessment information in the LA will appear in two sections: the operational section; treating the period during plant operations; and, the long term section, which will address the period from the end of the operating phase to the decay to harmless levels of the radionuclides. The operational section of the risk assessment will be based upon the facility design, and will include analysis on possible abnormal operations and accidents, with their potential consequences. The operational safety level of the plant will be determined from this analysis. The long-term safety analys is section will use event/fault tree and probability techniques based on geological and hydrological data, waste characterization and interaction, borehole plugging, rock testing, and mine modeling programs. Release scenarios will be developed, consequence analys is performed, and the long-term safety and environmental effects assessed.

An update to the LA will be performed based on the final design information and additional site data obtained during actual construction activities. Test data from the multiple barrier tests and spent fuel tests in the NSTF will be available and considered. 


\section{GEOSCIENCES - L3}

The objective of Geosciences is to provide support for site identification and evaluation studies, as well as input for the SCR, LA, and the ER. The knowledge obtained from this effort will be used to characterize the surrounding regional geology and natural geologic events which have occurred or which may occur in the future which must be considered in the design of a repository for radioactive materials in basalt rock. Base line monitoring of seismic activity in the region is conducted under this end function.

The program is subdivided into four major activities:

1. Projert. Management;

2. Geology;

3. Geophysics;

4. Seismic Monitoring.

The support activities are further divided into subactivities as noted in Figure 4.1 .

The Project Management activity is concerned with controlling costs and schedules, and providing technical management of the Geosciences end function, specifically in preparing schedules, work packages, and overall guidance of the other functional activities.

The Geology activity provides geologic reports, maps, and cross sections of the Pasco Basin and surrounding areas including the Columbia Plateau in the State of Washington. Special emphasis is on the structure, stratigraphy, and lithologic properties of the Columbia Plateau basalt in the Pasco Basin.

The Geophysics activity provides the technology for evaluating the structure and nature of the underlying rocks prior and subsequent to drilling activities. The physical properties and structure of the basalt rock underlying the Columbia Plateau are detailed on maps, cross sections, and graphs. Seismic reflection surveys, magnetotelluric surveys, and aeromagnetic surveys are made to determine the nature and structure of the basalt rocks at dept.h.

The Seismic Monitoring activity provides base line monitoring for parts of the Columbia Plateau that will be utilized in the development of seismic design criteria. Determination of ground acceleration as a function of depth in the Columbia Plateau is also part of this activity.

Major Accomplishments in FY 1979

The preliminary characterization of the geology of the Columbia Plateau was completed in FY 1979, including detailed mapping of the Pasco Basin and surrounding region, development of a preliminary tectonic 
Geosciences - L3 (continued)

understanding of the basin, and preparation of a geologic integration report. This report will provide the basis for candidate site identification. In addition, the structural analysis of the Yakima Fold structures and both magnetotelluric and aeromagnetic surveys of the Pasco Basin were completed. Surface and subsurface geologic maps were prepared.

Major Expected Results in FY 1980

Work during fiscal year 1980 will include the following areas.

Preliminary Geologic Integration Report. A summary will be made integrating the results of all geologic studies of the Columbia Plateau and the Pasco Basin from the previous years to provide data required for candidate site identification. This summary will be prepared for a preliminary geologic integration report.

Economic Geology Study. Economic geology studies will be carried out to identify and define the potential for economic resources including mineral resources, gas, and oil in potential repository target areas. Estimations will be made of relative value and the likelihood of exploitation of resources that could conflict with a terminal storage repository in basalt. The study will be started in FY 1980 and will consist of:

- An assessment of water resources based on existing records;

- An assessment of gas and oil resources based on existing exploration data, theoretical studies, drill hole records, and logs;

- An assessment of potential resources not presently valuable based on existing records and theoretical studies.

The study will result in a report to be issued in FY 1980.

Effects of Surficial Processes Study. A study of surficial processes will be carried out to determine if any naturally occurring event such as weathering, glaciation, or erosion at the ground surface of a repository site could credibly cause a breach of the repository containment. The denudation resulting from weathering and erosion is to be determined and then evaluated quantitatively along with rates of uplift and subsidence, which will be determined from other studies. The study will be performed in FY 1980 and will consist of field and laboratory studies of existing data.

Tectonic Studies. Tectonic studies will be performed to determine the structural stability of a potential repository site within the Columbia Plateau. This study will include assessments of historical seismic activity, present stress states, stress changes likely to occur, and any possible changes in geologic parameters due to movement along existing faults that could result in transport of radionuclides away from the 
Geosciences - L3 (continued)

repository. The study will be started and completed in FY 1980 and will be based entirely on existing data. The study will result in a report to be issued in FY 1981.

Assessments of Geothermal and Volcanic Activity. Assessment of geothermal and volcanic activity will be made to identify any abnormally high geothermal gradients, and evidence of recent volcanic activity in proximity to a potential repository site that could reasonably jeopardize its containment or safety. This assessment will be based on existing data including evidence of major past events, their relationship to existing tectonic structures, and other existing geologic data. The study will be started and completed in FY 1980 and will result in a report to be issued in FY 1981.

Repository Geology. A detailed study of the specific repository candidates sites will be made to provide information required to rank and evaluate candidate sites according to their suitability. Detailed mapping of the vicinity of the candidate sites will be conducted, interpreted, and compiled to provide stratigraphic, structural, and intraflow information.

Regional Geology. Regional geologic studies of the Columbia Plateau portion of Washington, Oregon, and Idaho will be conducted. Mapping of Cenozoic sediments overlying the basalt will be complete in order to further define important structures throughout the plateau, and to identify any geologic features that could potentially affect a repository in basalt.

Magnetotelluric Studies. Magnetotelluric studies will be conducted to provide further three-dimensional definition of the Pasco Basin subsurface geology. Data from these studies will be provided for identifying and ranking potential repository sites.

Seismic Surveys. Seismic surveys will be conducted in FY 1980 to more accurately define the subsurface geology of the candidate repository sites to support final site ranking and identification. The survey will be conducted on a grid pattern covering approximately 34 line miles and will result in a seismic evaluation report.

Multi-Level Aeromagnetic Surveys. Multi-level aeromagnetic surveys of repository candidate site areas will be made in FY 1980 to obtain greater definition of subsurface geologic structures to support final site identification. Surveys will be made at five levels for added dimension in potential repository areas.

Verification Studies of Specific Structures. Highly detailed geophysical surveys of specific structures which may affect potential repository sites will be conducted by Rockwell geophysicists in FY 1980 . The investigations will include magnetic, resistivity, gravity, and seismic surveys. These data will be used for final site identification and license application preparation. Results will be issued as inputs to geologic reports throughout FY 1980. 
Geosciences - L3 (continued)

Operations of Initial Seismic Network. Operations of the initial seismic network will continue through FY 1980 to provide seismic data for evaluation of tectonic stability. These data will be issued in a report on seismic net operations for consideration in repository site identification and license application in FY 1981.

Base Line Seismic Monitoring Plan. A base line seismic monitoring plan will be developed to define a network of seismic monitoring stations required to $\log$ a record of seismic and micro-seismic vibrations at a repository site. This record is necessary to verify structural and tectonic stability requirements for a potential terminal storage repository as defined in 10 CFR 60 and NRC and U.S. Environmental Protection Agency guidelines. This effort will be started and completed in FY 1980.

Microearthquake swarms are known to occur in some areas along the margins of the Pasco Basin: Downhole and surface coordinated monitoring in candidate sites (for repository) is required to measure what, if any, levels of stress are being relieved in the near vicinity of the site, what the source dimensions and source parameters are for any events nearby, and what levels of strain energy are propagated through the basalt from nearby events. Such monitoring activity is required not only to verify structural and tectonic stability (10 CFR 60-Subpart E), but also to assess the potential for inducing fractures and to quantitatively measure levels of activity for use in development of seismic design criteria, seismic design, and performance criteria before and during construction of a repository and associated subsurface facilities. 
ACTIVITY

Project Management

ACCOUNT CODE

L30

\section{OBJECTIVE}

The objective of Project Management is to direct the planning for the Geosciences end function and its activities and to provide authority to the functional groups to perform those activities and to assure that the end function objectives are met.

\section{DESCRIPTION}

This activity covers several. tasks which are performed by the Geosciences Manager within the Scientific Technologies Department, using other functional organizations as needed.

- Preparing and maintaining the plan(s) that defines project requirements and objectives, establishing schedules, - identifying resources, and serving as the basis for monitoring and analyzing project status and performance.

- Preparing and negotiating with functional organizations work packages which define by "End Function" and "Activity" the work to be accomplished by each functional organization, the schedules that are to be met, and the resources that are available.

- Monitoring and evaluating the work accomplished by each functional organization and defining corrective actions which are required to accomplish work package requirements.

- Keporting status, performance assessment, and corrective actions to the Department Manager, Scientific Technologies, and BWIP Director using standard Executive Control Meeting formats where feasible. 


\section{OBJECTIVE}

The overall objective of this activity is to provide the geologic input necessary for candidate site identification and characterization. These data will also provide information for the SCR, LA, and ER.

\section{DESCRIPTION}

Under this activity, studies will be continued and concluded which emphasize both the regional (Columbia Plateau) and local (Pasco.Basin) geologic setting. Studies will include both surface and subsurface stratigraphic and structural modeling. In addition, the tectonic character of the study area will be evaluated based on available data. The information gathered in these studies along with the information gathered in the work in previous years will be integrated to provide a current and comprehensive geologic data base. The ultimate goal of this integration effort will be to provide input for the site identification process and input for the SCR, LA, and ER. 


\section{OBJECTIVE}

The overall objective of this activity is to provide the geophysical input necessary for candidate site identification and characterization. These data will also provide information for the SCR, LA, and ER.

\section{DESCRIPTION}

Under this activity, geophysical studies will be continued and concluded which support the hydrology and geology activities needed for preliminary site characterization. The studies include seismic, magnetotelluric, and aeromagnetic surveys, as well as multiple geophysical studies of shallow geologic structures. The data gathered during this fiscal year will be integrated with previous geophysical data to provide input to the geologic and hydrologic studies for site identification and characterization and input for the SCR, LA, and ER. 


\section{OBJECTIVE}

Establish a monitoring network to analyze potential areas of seismic activity and improve the seismic risk evaluation capability. Provide input to the SCR, LA, and ER.

\section{DESCR IPTION}

A seismic monitoring network in the eastern part of the state of Washington is presently in place and will be expanded, improved, and upgraded as required to provide the most credible seismic data for the region. The monitoring network will provide the data base for analyzing areas of potential seismic activity and improving the seismic risk evaluation capability. Measurements of ground acceleration at the surface and at depth within the Pasco Basin will be made. 
HYDROLOGY - L4

The objective of Hydrology is to provide the hydrologic criteria and. evaluation techniques by which potential radioactive waste repository sites can be identified and evaluated. These data will also be used as input to the SCR, LA, and ER.

The program is subdivided into four activities:

1. Project Management;

2. Hydrology;

3. Testing Support;

4. Drilling Support.

The support activities are further divided into subactivities as noted in Figure 4,1 .

The Project Management activity is concerned with controlling costs and schedules, and providing technical management of the Hydrology function, specifically in preparing schedules, work packages, and overall guidance of the other functional activities.

Hydrology will evaluate the regional and local surface and ground-water flow systems. Conceptual models of these flow systems will be developed to determine the rate and direction of ground-water movement.

Testing Support will provide the personnel and equipment required to conduct borehole tests to measure in situ hydrologic and geophysical parameters and to collect water samples for analys is.

Drilling Support provides the boreholes required to evaluate the subsurface hydrology and provides core for chemical and physical analysis in support of the geologic and engineering program.

\section{Major Accomplishments in FY 1979}

Hydrologic testing and geophysical logging continued on boreholes drilled in FY 1978 and previous years. Preliminary regional and Pasco Basin hydrologic studies were completed and preliminary near-field scenario studies run. In addition, the three-dimensional Rockwell Hanford Finite Element (RHAFE) computational ground-water flow model was verified by comparisons to analytical solutions. A hydrologic integration report is being prepared for issuance in early FY 1980. 
Hydrology - L4 (continued) ${ }^{\circ}$

Major Expected Results in FY 1980

Work during FY 1980 will include the following areas.

Preliminary Hydrology Integration Report. A summary will be made integrating the results of all hydrologic studies of the Columbia Plateau and the Pasco Basin from the previous years to provide the basis for site identification.

Advanced Hydrology Integration Report. All the hydrologic data gathered pertaining to the Pasco Basin and the Columbia Plateau will be integrated into a final hydrologic-siting evaluation report to be issued in $F Y$ 1981. This report will contain the updated conceptual ground-water model based upon data made available during late FY 1979 and the first six months of FY 1980.

Site Characterization Report. In addition to the effort on the preliminary and advanced hydrology integration work, manpower and other resources will be reserved to specifically address particular items required in the SCR and to assure that the hydrology portion of the SCR is complete and correct in both format and content. Such a procedure is also planned with regards to the possible preparation of the ER and LA.

Modeling. A systematic analys is and prediction of ground-water flow paths and selected solute travel times from candidate repository site(s) to biosphere for long-time periods will be conducted and reported as part of the Advanced Hydrology Integration Report. It is expected that significant uncertainty will exist at this point so that the analyses will focus upon ranges of predictions which can be provided as a result of the available input data and interpretations.

Ground-Water Monitoring Criteria. The purpose of this activity will be to prepare criteria and requirements for monitoring potential effluents from the repository through ground-water pathways. The study will identify viable, alternative strategies and assess them in the context of temporal and spatial trade offs, capabilities of available instrumentation, and economics. Recommendations will be made regarding the need for further experiments. (such as tracer studies) to confirm the adequacy of design for the various alternatives. A report will be completed in FY 1980.

Drilling. Seven boreholes will be drilled during FY 1980 (Figure 4.2) to evaluate the hydrology, geology, and seismicity of potential repository sites. Five basalt core holes will be drilled to allow measurement of hydraulic properties and hydrochemical analyses of samples taken from aquifers penetrated as drilled. Minimal data of this nature presently exist, especially for the Wanapum and Grande Ronde Basalts. 


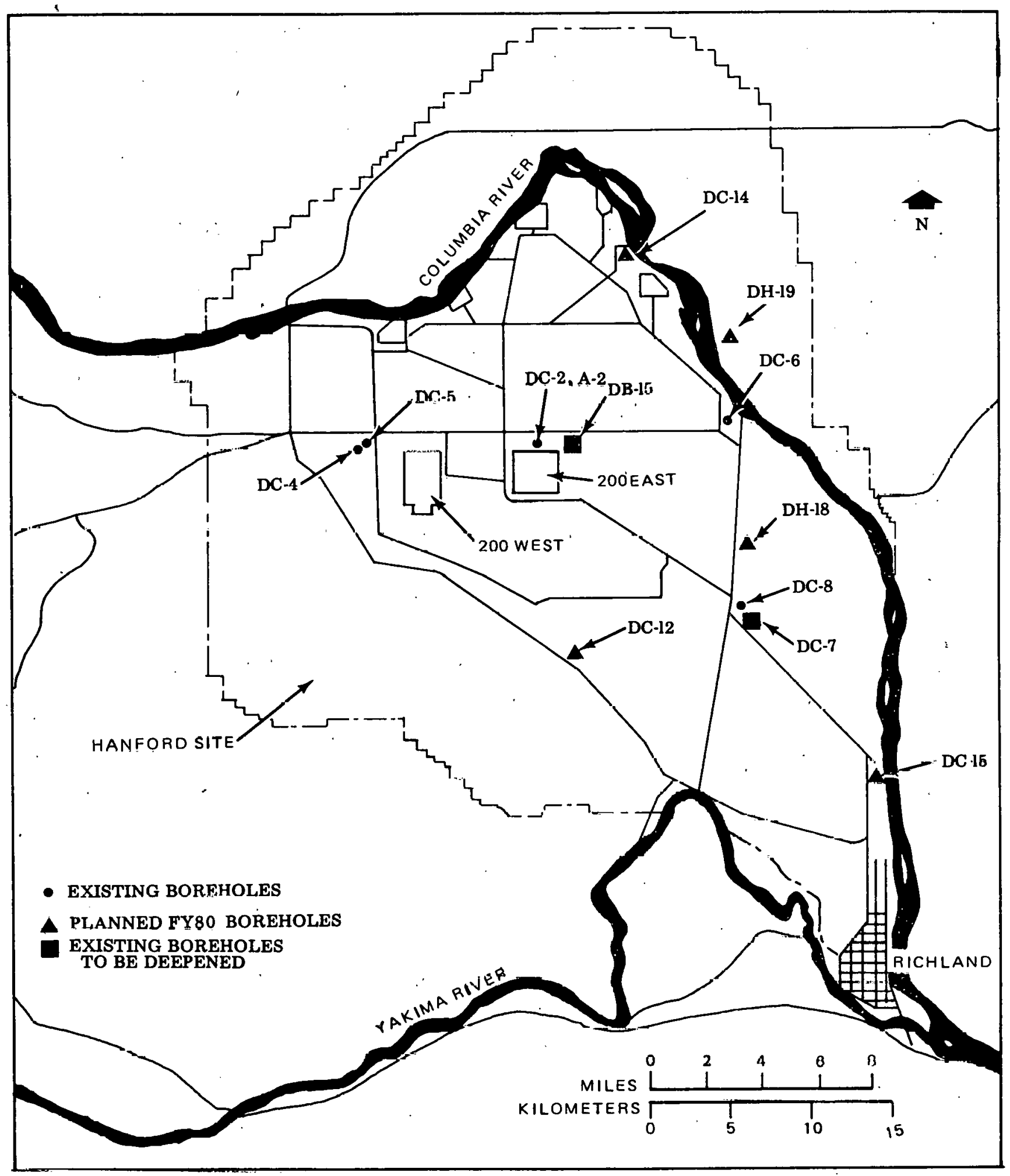

FIGURE 4.2. Boreholes--Basalt Waste Isolation Project. 
Sediments of the Ringold Formation will be cored in two shallow holes, $\mathrm{DH}-18$ and $\mathrm{DH}-19$, to provide paleomagnetic data useful to detect and date post-Columbia River Basalt deformation. The holes were located so as to obtain a representative cross section of the Ringold Formation and will be completed in FY 1980.

Two of the basalt core holes, DB-15 and DC-14, will be completed in FY 1980 through the Vantage Interbed and are primarily for investigation of hydraulic and hydrochemcial properties of the Saddle Mountains and Wanapum Formations. An existing deep borehole, DC-7, wi 11 be extended from 4,100 feet below ground surface to 5,000 feet in FY 1980. Valuable and previously unavailable data on the lower Grande Ronde Basalt will be obtained from this borehole.

Two deep core holes, $\mathrm{DC}-12$ and $\mathrm{DC}-15$, were located outside potential repository areas, but in zones where additional data are required on geologic and hydraulic properties and, in particular, to address the question of potential discharge to the Columbia River. Drilling of these holes will continue into the middle of FY 1981.

Hydrologic Testing. This research is divided into two basic efforts. The first effort is a geochemical sampling and analytical program will be conducted to characterize the chemistry of basalt ground waters and to evaluate their origins and residence times. Water samples will be collected along specific intervals in new boreholes completed in FY 1980 and within selected existing boreholes. Some spring samples from the Rattlesnake Hills area will also be analyzed and the results correlated to those chemistries of the deep.basalt ground-waters. The second effort is hydrologic testing, which involves the physical, in situ injection or. withdrawal of water from selected intervals to qualify the rock hydrologic characteristics. These include items such as fluid potential, permeability, and storage coefficient. Tests will be performed by Rockwell personnel during and following drilling in each borehole completed in FY 1980. Long-term tests are planned at two of the existing borehole sites. Long-term tracer tests will be conducted for determining dispersion coefficients, ground-water flow velocities, and effective porosities. Information gained from these studies will be input to flow and transport modeling. Studies will also be performed on determining the water content within specific basalt core samples.

Geophysical Logging. In support of the repository site selection effort, geophysical logging services will obtain in situ physical parameters that will aid the hydrologic, geologic, and engineering evaluation of the Columbia River Basalt Group. Typical parameters that will be evaluated are porosity, density, resistivity, lithology, fractures, temperature, etc. during FY 1980. An appraisal of existing logs was made prior to establishing the logging program for FY 1980. From the appraisal of the FY 1979 logs, a suite of logs was decided for logging FY 1980 boreholes and selected existing boreholes. 
Hydrology - L4 (continued)

ACTIVITY Project Management ACCOUNT CODE L40

\section{OBJECTIVE}

The objective of Project Management is to direct the planning for the Hydrology end function and its activities, provide authority to the functional groups to perform those activities, and to assure that the end function objectives are met.

\section{DESCR IPTION}

This activity covers several tasks which are performed by the Hydrology Manager within the Scientific Technologies Department and using other functional organizations as needed.

- Preparing and maintaining the plan(s) that defines project requirements and objectives, establishing schedules, identifying resources, and serving as the basis for monitoring and analyzing status and performance.

- Preparing and negotiating with functional organizations work packages which define by "End Function" and "Activity" the work to be accomplished by each functional organization, schedules that are to be met, and the resources that are available.

- Monitoring and evaluating the work accomplished by each functional organization and defining corrective actions which are required to accomplish work package requirements.

- Reporting status, performance assessment, and corrective actions to the Department Manager, Scientific Technologies, and the BWIP Director using standard Executive Control Meeting formats where. feasible. 


\section{OBJECTIVE}

Provide the regional and local hydrologic data required to qualify basalt as a radioactive waste storage medium. Data acquired will be used to identify and evaluate a site(s) for a radioactive waste repository, and to evaluate rate and direction of ground-water movement through both the confined and unconfined flow systems.

\section{DESCR IPTION}

Under this activity, studies will be conducted which emphasize both the regional (Columbia Plateau) and local (Pasco Basin) flow systems. These studies will include surface hydrology, subsurface hydrology, and conceptual and computational modeling. The data obtained will specifically define the hydrology of the Columbia River Basalt Group within the Columbia Plateau in the State of Washington. Regional and local ground-water models will be developed to predict the rate and direction of ground-water movement. 


\section{OBJECTIVE}

Provide the personnel and equipment required to conduct in situ geophysical logging and hydrologic testing in boreholes in the Columbia Plateau basalts.

\section{DESCRIPTION}

This activity is divided into the following subactivities.

- Hydrologic Testing

Hydrologic Testing subactivity provides the personnel and equipment required to measure various in situ borehole parameters to evaluate the rate and direction of ground-water movement. Holes will be tested throughout the Pasco Basin to determine the hydraulic properties of individual subsurface strata. These properties will be used to model the subsurface of the basin. Geochemical sampling and analys is will be conducted to characterize the chemistry of various ground waters to evaluate their origin and residence times. Long-term tracer tests will be conducted to determine the dispersion coefficients, permeabilities, flow velocities, and effective porosities of selected rock horizons.

- Geophysical Testing

The Geophysical Testing subactivity provides the personnel and equipment necessary to measure various in situ physical parameters such as porosity, permeability, velocity, lithology, Young's modulus, density, etc., which assist the geologic, engineering, and hydrology programs. 
OBJECTIVE

Provide the personnel and equipment to conduct a drilling and coring program to provide boreholes for hydrologic testing and geophysical logging, and to provide core for chemical and physical analys is. Drilling Support also provides technical support to evaluate tunnel and shaft boring equipment in support of the repository project.

\section{DESCR IPTION}

This activity is divided into the following subactivities.

- Specific Holes

Specific Holes subactivity provides drilling and related services within the Columbia Plateau basalts. Drilling services will provide boreholes necessary to investigate the subsurface geology, hydrology, and engineering properties of the Columbia Plateau basalts. Borehole sites will be selected to minimize penetration of strata which could reasonably be expected to be a potential repository site. Drilling of approximately 25,000 feet is expected in the FY 1979-1981 period.

- Orilling Technology

Drilling Technology will investigate the availability and capability of equipment for boring large-diameter tunnels and shafts in site-specific basalts. 


\section{ENGINEERED BARRIERS - L5}

The Engineered Barriers end function is concerned with definition of the need for and specification and testing of natural and man-made materials which can be used to plug the borehole of a basalt cavern or which can be used as an overpack to surround nuclear waste forms and containers. The primary goal of this end function is to specify a set of multiple barriers--engineered and natural--which will ensure that radionuclides from emplaced wastes do not reach the biosphere in unacceptable quantities. The physical and chemical conditions that exist within a repository strongly affect the stability and effectiveness of barrier materials. Therefore, the definition of repository conditions under planned operating and potential accident scenarios is an important Engineered Barriers activity.

The program is divided into three dulivities:

\section{Project Management;}

2. Multiple Barriers;

\section{Borehole Plugging.}

Each of these activities is further divided into subactivities as noted in Figure 4.1 .

The Project Management activity is concerned with controlling costs and schedules, and providing technical management of the Engineered Barriers end function, specifically in preparing schedules, work packages, and overall guidance of the other functional activities.

The Multiple Barriers activity emcompasses the determination of potential chemical reactions between spent fuel, canister material, potential engineered barriers such as overpack materials, and the repository materials (basalt, clay, etc.). Reactions with other waste forms which have been considered for emplacement and the repository materials are also being examined. Concurrently, the rates of radionuclide transport through basalt and other materials surrounding the canister containing spent fuel and the distance of this migration are being determined. These data will define the types and amounts of radionuclides, if any, which may be released to the environment. This activity is focused to consider barrier requirements for radionuclides known, because of their chemical properties, to have the greatest potential for migration through basalt materials. Appropriate barrier materials will be selected and engineered to minimize radionuclide release from the wastes.

The Borehole Plugging activity provides data for identifying materials suitable for plugging boreholes drilled through multilayered basalt flows. The methods used to emplace these materials are also identified. Cementing agents are needed to seal boreholes and assure that ground water will not channel along these structures in the future. 
Engineered Barriers - L5 (continued)

Major Accomplishments in FY 1979

In FY 1979, the characterization of the basalt secondary minerals from cores in the Columbia Plateau basalts was completed. These analyses placed special emphasis on secondary mineralization of basalts in potential repository horizons. Initial long-term nonradioactive simulations of nuclear waste interactions with reference to repository materials under hydrothermal conditions were also completed. Sorption experiments with radionuclides have been carried out under both near- and far-field repository conditions. The results of the sorption experiments are important for both radionuclide transport modeling and for the design of barrier systems. Criteria for borehole plugging components were developed, and preliminary testing and design of borehole plugging equipment and materials was completed and reported.

\section{Major Expected Results in FY 1980}

Multiple Barrier Studies will be continued and expanded in FY 1980 in preparation for preliminary hot cell demonstrations. These investigations will provide the information needed to select assemblages of multiple barriers for each waste form. The chemical reactions which may occur near waste canisters (phase transformations, dissolution, mineral precipitation) will be examined in further detail using simulated waste forms to provide source term information for the repository under accident conditions and to prepare for the hot cell demonstrations. The effectiveness of man-made materials, basalts, and basalt secondary minerals in retarding the migration of radionuclides in solution will be assessed. Precipitation and sorption/desorption experiments will provide information for modeling the movement of radionuclides in the mineralgroundwater environment.

In FY 1980, characterization of basalt, secondary minerals, ground-water, and waste forms wi 11 continue. Additional basalt from basalt flows being considered for a waste repository and several upper flows which might influence radionuclide migration will be characterized. Secondary minerals in selected sections of slant core from core hole DC-2 will be characterized and compared to secondary minerals found at similar depths in $D C-2$ (vertical) and other cores to help settle the question of horizontal homogeneity of secondary mineral assemblages in basalt flows. A literature search of radiation effects on basalt wi11 be completed in FY 1980 and documented in FY 1981. The effects of radiation on basalt in the immediate vicinity of the repository must be examined to determine what detrimental effects, if any, the high radiation fields may have upon the structure and the sorptive capacity of basalts. These radiation effects will be studied under controlled laboratory conditions. Kilogram quantities of reference basalts and secondary minerals will be prepared and characterized for experimental use. 
Engineered Barriers - L5 (continued)

A study of ground-water compositions which result from hydrothermal interactions with basalt will be initiated. These ground waters will be examined as a function of temperature, pressure, and mineral environment. The chemical stability of reference synthetic ground waters required for multiple barriers experimentation will also be investigated as a function of time and storage conditions.

The chemical and physical properties of the leading candidate waste forms will directly influence the number and types of engineered barriers which must be provided in a geologic nuclear waste repository. The chemical and physical characteristics of spent fuel elements relevant to storage in basalt will be determined from the 1 iterature. Simulated high-level waste form candidates will be prepared in FY 1980 for experimental use. These simulated wastes are required for hydrothermal reactions tests which will lay the ground work for later, hot cell testing.

Computer simulations of the chemical regime which will exist in the near field region of a repository in basalt located on the Hanford Site will be required to support and extrapolate the results of the hydrothermal barrier demonstrations. Development of a computer code and data base which will be used for such simulations will begin in FY 1980 . This code will include sorption and thermal effects in the near field. The program will also have the ability to model chemical changes in the wastebarrier-basalt-secondary minerals-ground-water system as a function of time.

Sorption experiments will be continued in an effort to measure the ability of basalt, secondary minerals, backfills, interbed materials and upper sediments to retard the migration of radionuclides which are likely to be mobile in or near the repository. Laboratory studies of sorption on candidate overpack/backfill materials will be initiated.

Determinations. of the effects of temperature, pressure, and oxygen concentrations on the sorption of radionuclides on basalt and secondary minerals will be continued. These data provide vital inputs to both barrier design and the radionuclide transport modeling efforts.

Smal1-scale hydrothermal stability testing of simulated waste forms in a basalt-ground-water environment will continue. The reaction products and aqueous solutions which result from these experiments will be characterized in detail. In FY 1980, work will begin on the development of experimental methods and equipment or characterizing the products of advanced hydrothermal tests. The preparation of off-site hot cell facilities for this testing will also begin.

Canisters and overpack/backfills are the only major barriers which can be manipulated to ensure the integrity of the repository for a given waste form. In FY 1980, literature studies to identify candidate materials for fulfilling these functions will be completed and reported in FY 1981. A ranked list of candidate materials will be prepared. The leading candidate materials will be tested under conditions similar to those 
Engineered Barriers - L5 (continued)

which may be found in a repository. Experiments to measure the resistance of various canister materials to attack by ground water under site-specific hydrothermal conditions will be initiated. Experimental evaluation of overpacks will stress their performance under hydrothermal conditions, reactions with key mobile radionuclides, and include initial testing of mechanical, sorptive, redox, and $\mathrm{pH}$ buffering properties. This work will lead to a refined candidate overpack materials list.

A program will also be initiated to document information generated within the activity and examine it for accuracy, reliability, and completeness. A demonstration of this concept will be performed on newly acquired data from the ground-water characterization task.

Laboratory testing will be performed to establish the suitability of potential plugging materials and placement techniques for a repository in basalt. The materials will be subjected to a variety of physical and chemical tests. Potential reactions of plugging materials with wall rock, ground water, and other candidate plugging materials will be investigated. The stress-strain behavior of plugging materials as a function of time will be measured at both ambient (pre-isolation) and elevation (post-isolation) temperatures. The rates of erosion, etching, or dissolution of plug materials under expected conditions in and near the repository will also be examined. The permeabilities of candidate plugging materials under simulated conditions will be determined in order to remove from consideration plug candidates which would provide an easy pathway for radionuclide-bearing ground waters.

Early in FY 1980 a plan for physical and geochemical testing of plug materials and plugging techniques will be prepared. This plan will include the experiments necessary to prepare for the initial field test of plug materials and plugging techniques.

Laboratory scale testing of borehole plug configurations will be initiated. These tests will allow measurements of the permeability of scale model plugabasalts systems. The strength of the bond between multiple plug materials, and between the plug materials and the basalt will be measured. These experiments will also include mesurements of the shrinkage (or swelling) of candidate plugs under a variety of temperature-pressure-chemical environment conditions which may exist in or near the repository and the shaft/borehole environment. 


\section{OBJECTIVE}

The objective of Project Management is to direct the planning for the Engineered Barriers end function and its activities, to provide authority to the functional groups to perform those activities, and to assure that the end function objectives are met.

\section{DESCR IPTION}

This activity covers several tasks which are performed by the Engineered Barriers Manager within the Scientific Technologies Department.

- Preparing and maintaining the plan(s) that defines project. requirements and objectives, establishing schedules, ident ifying resources, and serving as the basis for monitoring and analyzing status and performance.

- Preparing and negotiating with functional organizations work packages which define by "End Function" and "Activity" the work to be accomplished by each functional organization, schedules that are to be met, and the resources that are available.

- Monitoring and evaluating the work accomplished by each functional organization and defining corrective actions which are required to accomplish work package requirements.

- Reporting status, performance assessment, and corrective actions to the Department Manager, Scientific Technologies, and BWIP Director using standard Executive Control Meeting formats where feasible. 


\section{OBJECTIVE}

The objective of this activity is to determine the potential chemical reactions between emplaced nuclear waste and its repository environment. The reactions of canister materials, ground water, basalt, alteration minerals, and their effects will be considered. Candidate man-made materials which could be used to surround the waste and act as an effective retardant to migration of radionuclides to the surrounding environment will be defined and tested.

\section{DESCRIPTION}

This activity is divided into the following subactivities.

\section{- Characterization}

The objective of the characterization activity is to examine the characteristics of waste forms being considered, various engineered barriers, the deep basalts, and any secondary minerals filling voids and fractures. Chemical characterization of the ground water is obtained from the hydrology programs.

\section{- Emplacement Environment}

The objective of this work is to define the environment of a deeply buried repository in basalt under normal operating, backfilled, and accident conditions. This information will be used to assess the containment of waste radionuclides within a repository. The environmental conditions to be defined include chemical composition and origin of the ground water, mineral composition of the basalt and secondary minerals, the characteristics of spent fuel and other specified waste forms, and potential reactions between these materials and ground water.

- Waste/Barrier/Rock Interactions

The objective of this study is to determine waste/container/ overpack/basalt/ground-water interactions and to assess their effect on radionuclide retention. Individual barriers to migration will be examined for radionuclide retention. Reaction products from hydrothermal reactions will be identified and assessed as long-term storage sites for radionuclides.

- Barrier Optimization

The effectiveness of overpack, container, and waste form barriers will be established by laboratory experiments. Scouting studies on overpack materials and containers will lead to selection of reference materials for use in barrier specification. Hot cell techniques will be used to perform experiments with actual waste forms (spent fuel, glass, ceramics). 


\section{OBJECTIVE}

The objective of this activity is to develop a borehole plugging system for long-term plugging of boreholes in a'basalt. and sedimentary geologic sequence at the Hanford Site. This objective includes developing materials, machines, and techniques for borehole plugging.

\section{DESCR IPTION}

This activity is divided into the following subactivities. These phases are interdependent and progress concurrently until the final specifications for borehole plugging are written, at which time the system will be demonstrated at the Hanford isite.

- Laboratory and Material Studies

Laboratory and Material Studies will include defining the chemical and physical environment of the boreholes to be plugged and then locating and testing materials suitable for long-term plugging. The range of conditions in the boreholes at the Hanford Site wi11 probably require at least two types of materials for suitable plugging. Special materials and emplacement equipment witl be developed as needed, where required materials and equipment are not available as standard items.

\section{Specification Preparation}

Specification preparation will include a thorough evaluation of the results of the material studies and the borehole plugging machine design program before the specifications are.written. Specifications for the demonstration, a test plan, and test operating procedures wit1 be preparen.

- Demonstration

The demonstration will include preparation and instrumentation of shallow large- and small-diameter boreholes at Hanford to refine the standard operating procedures and ensure that the specifications can be achieved. If necessary, plugging of tunnels up to 20 feet in diameter may be demonstrated. After the system has been demonstrated in shallow holes, deep boreholes of selected diameters may be p.lugged in order to estimate the time and cost of full-scale borehole plugging. 
The size range of boreholes to be plugged may require development of several machines to be used to place the material in the borehole and assure a quality plug. These machines will have to be instrumented to record the condition of the plug during emplacement because the plug cannot be inspected after completion. The bottom of the borehole will probably be dry, while the top (the region on the unconfined aquifer) of the hole will be wet after the steel casing has been removed. Several types of machines may be developed for use in each size hole unless one type of material can be developed which can be guaranteed for long periods of time. 


\section{NEAR-SURFACE TEST FACILITY DESIGN AND CONSTRUCTION - L6}

The NSTF is a multipurpose test facility for in situ testing of basalt. The tests to be conducted in the facility are designed to:

1. Assess the feasibility of basalt as a repository medium;

2. Provide the basis of design for key repository elements;

3. Demonstrate placement, storage, and retrieval of spent fuel canisters in an underground basalt environment;

4. Demonstrate spent fuel monitoring capability in an underground basalt environment.

The NSTF is to be located on the west end of Gable Mountain on the Hanford Site near Richland, Washington. When completed, the farility will consist of approximately 3,000 feet. of underground workings, including access tunnels, test rooms, and a computer room. The initial phase, which is to conduct the electric heater tests, is scheduled for test startup in FY 1980. The second phase, which is for the conduct of tests utilizing radioactive materials such as spent fuel and vitrified waste, is scheduled for test startup in FY 1982.

Phase I will require the excavation of approximately 21,000 cubic yards of material from the 2 portal areas and the development of approximately 1,800 feet of underground workings. These will vary in size from an 8-foot-diameter for the east access tunnel to a 23-foot-diameter for the accelerated heater test room. This phase will have a ventilation (or fan) house, located at the mouth of the east portal, to provide ventilation. The east tunnel has a slight downgrade reaching a point 25 feet below the floor of the Phase I test room. This allows emplacement of test instrumentation beneath the test room floor. The extensnmeter room was developed to provide access to this instrumentation. The computer room with provision to record and process the information collected from the tests is located between the two portal areas.

Phase II will require the excavation of an additional 25,000 cubic yards of material from the portal area and another 1,200 feet of underground excavation. This phase will be separated from Phase I by a series of air locks and will have its own ventilation system. Vertical holes from the surface to the test room are used for ventilation and power cable access.

The project is divided into nine major activities:

1. Project Management;

2. Design-Phase I;

3. Construction-Phase I;

4. Safety and Environmental Analysis-Phase I; 
Near-Surface Test Facility Design and Construction - L6 (continued)

5. Decommissioning-Phase I;

6. Design-Phase II;

7. Construction-Phase II;

8. Safety and Environmental Analysis-Phase II;

9. Decommissioning-Phase II.

Major Accomplishments in FY 1979

Tunnel construction and all drill-holes for the Phase I heater tests were completed by September 27, 1979. Phase I Title II design was completed and acceptance test procedures (ATPS) were written and approved. This design included relocation of the computer facility from underground to above ground. Procurement of long lead time items was started and is on schedule.

The Phase II facility conceptual design report was completed on schedule and transmitted to the DOE-RL. This report provides the necessary system design descriptions, trade studies, special requirements, and cost estimates to proceed directly to Title II design.

The revised Phase II functional design criteria was transmitted to DOE-RL on June 22, 1979 for review and approval.

The bottom loading transporter (BLT) Title I design was completed by Atomics International. The Rockwell Title II design effort for the BLT is 66 percent complete.

An environmental assessment document was issued by DOE-RL in December 1978.

\section{Major Expect.ed Result.s in FY 1980}

Work during 1980 will include the following

Facility Design. Design efforts for the NSTF in FY 1980 will result in the completion of the Title II design for the Phase II facility and site requirements. This will provide the engineering design and drawings for the construction of the necessary facility requirements such as heating, ventilation, and electricity in support of eventual radioactive materials storage tests in the basalt facility. Rockwell approved Title II design drawings, acceptance test procedures, procurement specifications, and the cost report will be completed during FY 1980. 
Near-Surface Test Facility Design and Construction - L6 (continued)

Remote Handling System. Title II design of the remote handling system required for handling radioactive materials within the test facility will be completed and fabrication started in FY 1980. Design services will provide engineering design and drawings on November 30, 1979. Fabrication of the system subassemblies will be completed, and preliminary assembly for testing will be approximately 50 percent complete on September 26, 1980. The remote handling system includes the BLT, remotely operated grapples (two), test hole liners, and test hole shield plugs.

Phase I Construction. Construction of the Phase I portion of the NSTF will be completed on May 23, 1980. This construction effort will provide the facility and equipment installation to support the electric heater tests simulating the effects of nuclear waste emplaced in basalt to verify the effects of radiation heating in a basalt storage medium.

NSTF Phase I Title III Design Services. Title III inspection services and as-built drawings will be provided in FY 1980 to ensure compliance with the construction documents and to produce construction drawings for record, operation, and maintenance requirements. Inspection logs will be provided at the completion of facility requirements construction on May 23, 1980. The as-built drawings of the facility requirements will be provided in June 1980.

Phase II Test and Instrumentation Holes. 'The test and instrument boreholes required for the placement of test instrumentation and canisters of nuclear waste in the Phase II portion of the NSTF will be completed on July 25, 1980. The acceptance test report and the location survey for test boreholes will be provided on August 29, 1980.

Phase II Facility Construction. Construction efforts in FY 1980 for the Phase II facility and site requirements will be started. This will include electrical, mechanical, structural, and safety systems as well as the site work required to support spent fuel testing in the basalt test facility.

Phase II Title III Design Services. Inspection services and as-built drawings will be provided for the Phase II facility and site work to ensure compliance with the construction documents and to provide as-built drawings for record operations and maintenance requirements. Inspection logs and as-built drawings will be maintained concurrent with construction effort.

Continuing Environmental Review. Environmental analysis and review of the NSTF in FY 1980 will provide design review inputs at the completion of the remote handling system design and in periodic reports on an unscheduled basis following Gable Mountain site visits. 
Near-Surface Test Facility Design and Construction - L6 (continued)

Near-Surface Test Facility Safety Assessment Document. The NSTF design documents will be reviewed and assessed to. provide a safety assessment document which will serve as input for the safety and readiness review to ensure a safe and operable facility.

Continuing Safety Review. Safety analysis and review of the NSTF in FY 1980 will provide design review inputs at the completion of the Phase II facility design, at the completion of the remote handling design, and unscheduled periodic reports based on ongoing site visits and review of activities. 


\section{OBJECTIVE}

The objective of Project Management is to direct the planning for the NSTF Design and Construction end function and its activities, provide autharity to the functional groups to perform those activities, and to assure that the end function objectives are met.

\section{DESCRIPTION}

This activity covers several tasks which are performed by the NSTF Design and Construction Project Manager reporting to the NSTF Program Manager.

- Preparing and maintaining the plan(s) that defines project requirements and objectives, establishing schedules, identifying resources, and serving as the basis for monitoring and analyzing status and performance.

- Preparing and negotiating with functional organizations work packages which define by "End Function" and "Activity" the work to be accomplished by each functional organization, schedules that are to be met, and the resources that are available.

- Monitoring and evaluating the work accomplished by each functional organization and defining corrective actions which are required to accomplish work package requirements.

- Reporting status, performance assessment, and corrective actions to the NSTF Program Manager and the BWIP Director, using standard Executive Control Meeting formats where feasible. 


\section{OBJECTIVE}

The objective of this activity is to provide the engineering design (Titles I and II) needed to construct the NSTF.

\section{DESCRIPTION}

This activity encompasses the design activity (conceptual, Title I, and Title II) for the facility needed to support the electric heater tests and to fulfill the requirements of DOE. Design of the tunnels and excavations was accomplished within Rockwell by the Basalt Engineering Unit. This represented approximately 1,800 feet of underground workings and 21,000 cubic yards of surface excavation at the 2 tunnel mouths. The Rockwell Utilities Function was responsible for the design of the electric distribution line serving the facility. This required upgrading approximately 1.5 mi les of existing 13.8-kilovolt ( $k v$ ) line and adding approximately 1.25 miles of new 13.8-kv line. Vitro Engineering Corporation (Vitro), Richland, Washington is responsible for the remaining portions of the design which includes the ventilation system, the underground electric system, the site work, and various underground structures related to the test, such as equipment enclosures and the computer room. 


\section{OBJECTIVE}

The objective of this activity is to provide the construction activities required to develop the NSTF.

\section{DESCRIPTION}

This activity encompasses the construction activity (including Title III inspection) for the facility needed to support the electric heater tests and to fulfill DOE requirements. Vitro is to provide the required Title III inspection service. The upgrading of the existing 13.8-kv electric distribution line was accomplished by the Rockwell Utilities Function. The new electric distribution construction (approximately 1.25 miles of 13.8-kv line) and the tunnels and excavations (approximately 1,800 feet of underground workings) are to be accomplished under a subcontract administered by the J. A. Jones Construction Services Company (JAJ), Richland, Washington, and managed by Rockwell. Remaining construction is to be by JAJ plant forces. 
ACTIVITY Safety and Environmental Analysis-Phase I ACCOUNT CODE L63

\section{OBJECTIVE}

The objective of this activity is to provide environmental and safety analysis and review for the NSTF-Phase I.

DESCRIPTION :

This activity is divided into the following subactivities.

- Environmental Review

Review NSTF design documents and visit the construction site for inspection of compliance with environmental assessments. Design review inputs will be provided on an unscheduled basis following Gable Mountain site visits.

- Safety Review

Provide review of construction safety of the NSTF site and provide review of NSTF by the safety review committee for the NSTF. 


ACTIVITY_Decommissioning-Phase I _ ACCOUNT CODE L64

OBJECTIVE

The objective of this activity is to decommission the Phase I portion of the NSTF and test operations at the end of the scheduled program.

\section{DESCRIPTION}

The test decommissioning will involve removal of test hardware and wiring and protective covering of test holes. 


\section{OBJECTIVE}

The objective of this activity is to provide the engineering design (Titles I and II) needed to construct the portion of the NSTF.

\section{DESCRIPTION}

This activity encompasses the design (conceptual, Title I, and Title II) for the facility and remote handling system needed to support the spent fuel test and to fulfill DOE requirements. Design of the tunnels and excavations was accomplished within Rockwe 11 by the Basalt Engineering Unit. This represented approximately 1,200 feet of underground workings and 25,000 cubic yards of surface excavation at the tunnel mouth. vitro is responsible for the remaining portion of the facility design which includes the ventilation system, the underground electric systems, the safeguards and security systems, and the site work. Atomics International, Canoga Park, California, is responsible for conceptual design and Title I design of the remote handling system. Title II design wi 11 be performed by Rockwell. 


\section{OBJECTIVE}

The objective of this activity is to provide the construction activities required to develop the spent fuel test portion of the NSTF.

\section{DESCR IPTION}

This activity encompasses the construction activity (including Title III inspection) for the facility and remote handling system needed to support the spent fuel test and fulfill DOE requirements. Vitro is to provide the required Title III inspection for the onsite construction. The tunnels and excavations (approximately 1,200 feet of underground workings) and facility construction are to be accomplished under a subcontract administered by JAJ and managed by Rockwell. 
ACTIVITY Safety and Environmental Analys is-Phase II ACCOUNT CODE L67

\section{OBJECTIVE}

The objective of this activity is to provide the environmental and safety analysis and review, and the safety assessment document for the NSTF-Phase II.

\section{DESCRIPTION}

This activity is divided into the following subactivities.

- Environmental Review

Provides for the analysis, data collection, and report preparation of the needed environmental assessments for the NSTF-Phase II. Design review inputs will be provided at the completion of the remote handling system design and on an unscheduled basis following Gable Mountain site visits.

- Safety Review

Provides review of NSTF-Phase II and review of the NSTF-Phase II design and criteria by the safety review committee. A safety assessment document will be provided and will serve as input to the safety and readiness review which will be performed to ensure a safe and operable facility. Design review inputs will be provided at the completion of the Phase II facility design, at the completion of the remote handling designs, and on an unscheduled basis following site visits and reviews of activities. 


\section{OBJECTIVE}

The objective of this activity is to decommission the Phase II portion of the NSTF and test operations at the end of the scheduled program.

\section{DESCR IPTION}

Decommissioning will be accomplished in two phases:

- Spent Fuel Test Phase;

- Facility Phase.

The test decommissioning will involve removal of test hardware and wiring and protective covering of test holes. Facility decommissioning will involve removal of facility fittings and restoration of the site to an environmentally acceptable condition. All radioactive material will be removed from the NSTF upon decommissioning. 
ENGINEERING TESTING - L7

This end function involves the planning, design, fabrication, and installation of test articles to be installed in the NSTF. It also includes the operation of tests to collect test.data which will be used to establish the feasibility of basalt as a repository medium and, finally, repository design. Rock testing and other miscellaneous special studies are also included as part of this program.

The program is divided into four activities:

1. Project Management;

2. Engineering Studies;

3. Phase I;

4. Phase II。

Each of these activities is further divided into subactivities as noted in Figure 4.1 .

The Project Management activity is concerned with controlling costs and schedules and providing technical management of all engineering testing. Specific work includes preparation of schedules, work packages, and overall guidance of other functional activities.

Thermal and mechanical properties of basalt are determined by laboratory testing of basalt cores. The data generated will be used as input for analysis and modeling of subsurface designs and experiments. other special studies will be performed during the course of the program to support the design needs of the repository.

The Phase I heater tests are being conducted to determine the thermomechanical response of basalt and verify the accuracy of predictive mathematical mine models. Specific test objectives will measure temperature, borehole deformation, and linear expansion. From these data, basalt physical properties will be calculated and used as an input for assessing the feasibility of basalt as a repository medium. Four tests will be conducted. The first test is a full-scale test to simulate expected repository conditions. The second test is to determine the capability of rock to accept heat and to determine the point at which decrepitation of the rock around the canister occurs. The third test is an accelerated heater test to simulate the longer-term response and interaction of canisters in a repository in basalt. The fourth test, the jointed block test, will consist of a series of short-term tests designed to measure specific rock mass properties under controlled conditions.

The Phase II test is a demonstration of the storage of nuclear waste in basalt. Spent fuel will be characterized, packaged, and shipped from offsite to the test facility where it will be received, loaded into a 
Engineering Testing - L7 (continued)

transfer cask, moved to a test area, stored, removed following completion of the test, and returned to an offsite storage location. A second test using vitrified waste will also be conducted.

Both the Phase I and Phase II tests will be operated to obtain data for licensing prior to start of repository operation. Following completion of the tests, the equipment will be removed and the facility will be decommissioned.

Major Accomplishments in FY 1979

Design of the Full-Scale Heater Test \#1 was completed. Procurement for the test was completed. Test plans for both the heater test (Phase I) and the nuclear test (Phase II) were completed. Rock testing of cores will be completed using core from holes already drilled.

Major Expected Results in FY 1980

Work will be conducted as follows.

Rock Testing. The current $\mathrm{plan}$ is to test a total of approximately 50 feet of core samples from the NSTF instrument holes (test cores to be selected by Rockwel1). This effort will include the following.

- Inspecting and logging cores supplied (to include a description of observable core mineralogy, rock fabric, and geologic fillings).

- The following testing will be conducted:

Uniaxial compressive strength;

Brazillian tensile strength;

Trlaxial compressive strength on intact and jointed samples at 3 confining pressures $(500,1,000$, and 2.000 pounds per square inch);

Modulus of rupture;

Static elastic properties (Young's modulus, Poisson's ratio, cohesion, internal angle of friction);

Density (bulk and grain);

Porosity;

Thermal expansion in the 20 - to 300 -degree Centigrade $\left({ }^{\circ} \mathrm{C}\right)$ range;

Thermal conductivity in the $20-$ to $300-{ }^{\circ} \mathrm{C}$ range; 
Engineering Testing - L7 (continued)

Specific Heat (20- to $300-{ }^{\circ} \mathrm{C}$ range);

Thermal diffusivity.

Heaters and Controllers. Efforts of Rockwell and subcontractor personnel will be directed to the following tasks.

- Accelerated Room Test--Modify heater design to meet test criteria; complete bid and award contract for procurement of material, fabrication, assembly, and testing of 61 heaters; complete 60 percent of action on the above contract; and, complete design of electrical circuitry for heater power. Bid and award contract for procurement, fabrication, assembly, and testing of 10 main controllers for FY 1981 .

- B lock Test Number 1--Modify heater design to meet block test criteria; complete bid and award contract for procurement of material, fabrication, assembly, and testing of 18 heaters; complete 85 percent of action on above contract; test 15 peripheral controllers; issue contract for procurement and modification of 4 voltage regulators, and procurement and wiring of 4 cabinets; and, design intercabinet wiring for controller installation.

- Block Test Number 2--Complete bid and award contract for procurement of material, fabrication, assembly, and testing of 18 heaters; complete 70 percent of action on the above contract; procure and test 4 main controllers; design intercabinet wiring; issue contract for procurement and modification of 4 voltage regulators; and procurement and wiring of 2 cabinets for FY 1981 .

Phase I Rock Instrumentation. Work in this area provides the rock instrumentation and data acquisition system interface for Full-Scale Heater Test \#2, Block Test 1, Block Test 2, and Accelerated Room Test, and provides for conducting the Goodman Jack Tests and overcoring tests.

- Ful1-Scale Heater Test \#2 rock instrumentation includes assembly and delivery of the instrument assemblies to the NSTF.

- Block Test 1 rock instrumentation includes: design of instrument assemblies; preparation of test procedures; procurement of sensors and associated materials; assembly and delivery of the instruments to the NSTF.

- Block Test 2 rock instrumentation includes: design of instrument assemblies; preparation of test procedures; procurement of sensors and associated materials and start of assembiy. 


\section{Engineering Testing - L7 (continued)}

- Accelerated Room Test rock instrumentation includes: design of instrument assemblies; preparation of test procedures; procurement of sensors and associated materials; assembly and delivery of the instruments to the NSTF.

- Goodman Jack Tests include: preparation of test procedures, conducting the testing and preparation of a test report on the modulus of elasticity of basalt.

- Overcoring tests include: preparation of test procedures; conducting the tests; and preparation of a test report on the in situ stress.

Phase I Data Acquisition. Work in this area includes the following components.

- Complete development of data acquisition system software and hardware for Full-scale Heater Tect. \#1 and \#2.

- Install data acquisition system equipment and software and complete acceptance testing for Full-Scale Heater Tests \#1 and \#2.

- Complete problem definition review and requirements analys is for Jointed Block and Accelerated Room tests.

- Complete training of operators for data acquisition system operation.

Phase I Site Characterization. Pre-test geologic site characterization is required to document the structural and physical composition of the rock mass before testing so that changes resulting from heating and testing can be easily identified to allow comparison of the NSTF geologic conditions with the conditions that prevail at the site selected for $a$ full-scale repository.

Results and data acquired from detailed geologic mapping, instrument borehole core logging, and impression packer mapping performed during $\mathrm{FY}$ 1979 will be integrated and reported. Follow-up impression packer mapping will be performed during heater testing.

Installation. The equipment to be installed provides for the Full-scale Heater Tests, Block Tests 1 and 2, and Accelerated Room Test in the NSTF. The equipment includes electrical heaters and controllers, rock instrumentation, miscellaneous electrical circuitry, and a data processing acquisition system with the necessary instrument readouts.

Operation. The facility will be operated using approved procedures. Phase I training will be completed June 1, 1980 and operations for the full-scale tests will commence thereafter.

Phase II. Work on rock instrumentation, test design support, and spent fuel acquisition will be carried on in support of the Phase II test plan once it is approved. 
Engineering Testing - L7 (continued)

Pre-test geologic site characterization is required to document the structural and physical composition of the basalt rock mass before testing so that changes resulting from the Phase II heating and testing can easily be identified and to allow comparison of the NSTF geologic conditions with the conditions that prevail at the site selected for a full-scale repository.

Rockwell geologists will map the entry tunnels and the Phase II test room. These maps will describe the rock mass mineralogy, fabric, and structure in detail. The geologists will also log core derived from the instrument boreholes and log-selected boreholes with the impression packers and a down-hole television camera. The test room will be comprehensively photographed for documentation. 


\section{OBJECTIVE}

The objective cof IProject Management is ito direct the Iplanning for the Engineering Testing rend function and its activities, to provide authority ito ithe ffunctiona 7 groups ito eperform sthose activities, rand to sassure that ithe end function robjectives are rmet.

DESCRIPTION

This activity covers several t'asks :which are ?performed by the Engineering Testing Manager.

- Preparing and imaintaining 'the iplian('s') that fof ines iproject requirements and sobjectives, restablishing schedütes, "ident if ying resources, and serving as the ibasis for imonitoring and analyzing :status and performance. T:

- Preparing and inegotiating with functional corganizations work lpackages which define by ".End IFunction" and "Activitity" the "work 'to 'be accomplished by each functional organization, schedules that are to be met, and the resources that are available.

- Monitoring and evaluating the work accomplished by each 'functiona'l organization and defining corrective actions which are required to accomplish work package requirements.:

- Reporting status, performance asses'sment, and corrective actions to the NSTF Program Manager and the BWIP Director's office using standard Executive Control Meeting formats where feas ible. 


\section{OBJECTIVE}

The objective of this activity is to provide rock testing (1aboratory testing of basalt cores and rock samples from the NSTF test and instrument holes and caverns), consulting services for rock mechanics, and special studies as required.

\section{DESCR IPTION}

Thermal and mechanical properties of basalt are determined by laboratory testing of basalt cores and the measurement of the in situ state of stress at designated locations by hydraulic fracturing in a borehole. Prior to testing, all basalt cores will be described and examined for mineralogy, rock fabric, and ali geologic discontinuities. Cores from boreholes will be retained for future verification.

The data acquired in this activity will be used for comparison with existing rock property data to establish a data base for Columbia Plateau basalt properties. The data generated will be used as input for analysis of modeling of subsurface designs and experiments.

Expert consultation will be provided by a mine consultant firm to assist in review of documents prepared as part of the project by other subcontractors, review of mining techniques utilized in the NSTF and other experiments, preparation of cost and schedule estimates for various construction activities, recruiting of personnel experienced in rock mechanics, and underground mining and mine system designs.

Advanced rock testing will be required for test holes for the Phase I and Phase II tests and for repository site selection. 


\section{OBJECTIVE}

The objective of this activity is to conduct thermal and mechanical tests in basalt which will provide repository design data. This objective includes:

- Defining the thermal related physical properties of basalt utilizing heater simulation tests corresponding to potential waste storage concepts;

- Defining the effects of fractures and discontinuities in the heated regime;

- Obtaining field data to corroborate and validate predicted heating effects to assist in repository design.

UESCRIPIIUN

The Phase I activity is divided into the following subactivities.

- Heaters and Controllers

This subactivity provides for the design, procurement, fabrication, testing, and calibration of the heaters and controllers required for the Phase I test sequences.

- Rock Instrumentation

This subactivity provides for the design, procurement, fabrication, testing, calibration, and installation support for the test instrumentation required to acquire data on the rock characteristic changes during the heater tests.

- Vata Acquisition System

This subactivity provides for the design, procurement, fabrication, testing, and calibration of the data acquisition and computer hardware, and for the preparation of the programing (software) required to control the system. Ihis system will acquire data from the rock instrumentation, process the data to correct for thermal effects and convert to engineering units, and provide recording and visual outputs for test control and data analysis.

\section{- Site Characterization}

This subactivity provides for the geophysical, hydrologic, and geologic input for complete characterization of the test area both before and after the heater tests. 
- Test Engineering Support

- This subactivity provides for the preparation of detailed test plans, and placement/arrangement/location details. Methods of collection, analysis, and presentation will be detailed. Consultation support will be provided as required. Safety and readiness review will be conducted.

- Equipment Installation

This subactivity provides for the installation of the rock instrumentation, the heaters, and the data acquisition system. It coordinates the efforts required by personnel from Rockwel1, site subcontractors, and rock instrumentation suppliers.

- Operation

Phase I operations will consist of performing Full-Scale Heater Tests $\# 1$ and \#2, the Accelerated Heater Test, and the Jointed Block Test. 


\section{OBJECTIVE}

The objective of this activity is to demonstrate the storage of nuclear waste in basalt. The activity will also demonstrate handling of waste underground in a repository environment.

\section{DESCR IPTION}

The Phase II activity is divided into the following subactivities.

- Heaters and Controllers

This subactivity provides for the design, procurement, assembly, testing, and calibration of the heaters and controllers to be used in spent fuel testing.

- Rock Instrumentation

This subactivity provides for the design, procurement, fabrication, testing, calibration, and installation support for the test instrumentation required to acquire data on the rock characteristic changes during the spent fuel storage demonstration.

- Data Acquisition System

This subactivity provides for the design, procurement, fabrication, testing, and calibration of those additions to the data acquisition and computer hardware, and for the preparation of the additional programming (software) required for the spent fuel rock instrumentation.

- Site Characterization

This subactivity provides for the geophysical, hydrologic, and geologic input for complete characterization of the spent fuel test portion of the facility before and after the storage demonstration.

- Test Engineering Support

This subactivity provides for the preparation of a detailed test plan and test procedures. It will provide test instrumentation placement/arrangement/location details. Methods of data collection, analysis, and presentation will be detailed. Consultation support will be provided as required. Safety and readiness review will be provided.

- Equipment Installation

This subactivity provides for the installation of the rock instrumentation, the borehole liners, the spent fuel handling equipment, and the additions to the data acquisition system. It coordinates the efforts required by personnel from Rockwell, site subcontractors, and rock instrumentation suppliers. 


\section{- Operation}

Phase II operations will consist of performing tests using canistered spent nuclear fuel. Two single canister tests are presently planned. Operations during Phase II testing will also include loading waste to be stored, obtaining data during the test phase, and removing the nuclear waste prior to facility decommissioning.

- Spent Fuel Preparation

This subactivity provides for the canistered spent nuclear fuel acquisition, generic fuel canister modification for use at the NSTF, canister fabrication, fuel characterization at Battelle-Columbus Laboratories, fuel encapsulation at the Engine Maintenance and Disassembly (EMAD) facility, and the various phases of fuel transportation. 


\section{REPOSITORY STUDIES - L8}

This activity involves the design of a nuclear waste repository in basalt. Preconceptual design, functional design criteria, and conceptual design establishing basic parameters were prepared prior to the start of conceptual design activities. Conceptual design of the repository will be conducted by an $A / E$.

The program is divided into seven activities:

1. Project Management;

2. Engineering Support;

3. Repository Design;

4. Long-Lead Procurement Support;

5. Construction Mariager (CM) Selection Support;

6. Construclion;

7. Site-Specific Tests.

Each of these activities is further divided into subactivities as noted in Figure 4.1 .

The Program Management activity is concerned with controlling costs and schedules and providing technical management of the Repository Studies function, specifically in preparing schedules, work packages, and overall guidance of the other functional activities.

An $A / E$ to provide design and engineering services was selected by a DOE $A / E$ evaluation board and source-selection officials with Rockwell personnel acting as technical advisors. The initidi phases of the repository design $w 111$ be the developinent of the conceptual design, and the establishment of a repository cost estimate. If feasibility is established and a decision is made by the Federal Government to proceed, Title I design will be initiated. This will require preparation of a budget request, "Schedule 44," for Congressional line item funding for a construction project.

Major Accomplishments in FY 1979

In FY 1979, the preconceptual design study was prepared and the functional design criteria were issued. These design criterla will govern the conceptual design to be done by the A/E (Kaiser Engineers/ Parsons Brinckerhoff Quade \& Douglas, Inc.). The $A / E$ is directly contracted by DOE.

Major Expected Results in FY 1980

We will initiate and perform conceptual design of a repository in basalt for the storage and disposal of nuclear waste and spent fuel. Conceptual 
Repository Studies (continued)

design will start during October 1979 and will be completed by September 1981. Conceptual design work will be performed by an A/E under Rockwell technical guidance.

Repository facility requirements include surface receiving and inspection facilities, shafts and tunnels providing access to the underground repository, underground facilities for storage of radioactive waste, equipment for remote handling and transporting of radioactive waste, and support systems.

The A/E will perform conceptual design work for the repository consisting initially of a review and evaluation of recommended engineering studies and the functional design criteria. The A/E will provide recommendations, cost estimates and schedules for performance of the engineering studies, and the conceptual design. The A/E will then proceed with the engineering studies and conceptual design including the following items:

- Work plan and supporting documents for performance of conceptual design;

- Conceptual design of the repository meeting the requirements for surface and subsurface facilities, shafts, remote handling systems, and support systems;

- Preliminary schedule and cost estimate for Titles I, II, III design and engineering, and facility construction and acceptance;

- Information to support submission of a Schedule 44 (Congressional Budget Data Sheet) requesting funds for repository design.

During FY 1980, all work on the first item above will be completed. In addition, approximately 50 percent of the work in the second and third items above will be completed. Work on the fourth item will be performed during FY 1981 .

In addition, the rationale for sinking an exploratory shaft will be examined and a test plan developed.

A meteorological station data collection plan will be issued to collect repository site data in compliance with NRC Regulatory Guide 1.23. 


\section{OB JECTIVE}

The objective of Project Management is to direct the planning for the Repository Studies end function and its activities, to provide authority to the functional groups to perform those activities, and to assure that the end function objectives are met.

\section{DESCRIPTION}

This activity covers several tasks which are performed by the Repository Studies Manager.

- Preparing and maintaining the plan(s) that defines project requirements and objectives, establishing schedules, identifying resources, and serving as the basis for monitoring and analyzing status and performance.

- Preparing and negotiating with the $A / E$ and supporting organizations the work to be accomplished by each organization, schedules that are to be met, and the resources that are available.

- Monitoring and evaluating the work accomplished by each organization and defining corrective actions which are required to accomplish work package requirements.

- Reporting status, performance assessment, and corrective actions to the BWIP Director's office using standard Executive Control Meeting formats where feasible. 


\section{OBJECTIVE}

The objective of this activity is to support the efforts of the DOE A/E evaluation board in selecting a qualified $A / E$ for the design of the nuclear waste repository in basalt and to develop functional design criteria and preconceptual design information that the A/E can use as the basis for conceptual design.

\section{DESCR IPTION}

This activity is divided into the following subactivities.

\section{- Functionar Design Criteria}

The functional design criteria for the repository will be developed as a product of preconceptual design. During this phase of design, flow diagrams, trade studies, safety criteria, cost estimates, schedule details, equipment lists, and layout drawings will be prepared to further define the repository prior to start of the conceptual design by an $A / E$.

The system design description and cost estimates will be prepared for each of the major repository subdivisions as follows:

Surface facilities design includes all major buildings, support structures, site utilities, and services required to support the repository;

System design includes mine ventilation/cooling, electrical, communications, instrumentation, radiation monitoring, security, filtration, and water disposal;

Shafts and headframes consist of man/materials shafts, the construction and ventilation shaft, radioactive waste shaft, and emergency escape;

Waste handling design includes all transport, hot cell and shaft/surface/subsurface remote handling equipment, including bridge cranes, manipulators, conveyors, monorails, and hoist operations;

Subsurface designs include the main and subhaulage ways, disposal areas, maintenance areas, receiving shaft stations, shielding at radioactive waste areas, sumps, and canister holes.

\section{- A/E Selection Support}

In order to support the efforts of the $A / E$ evaluation board, the following efforts will be required: 
Provide technical assistance as requested by DOE;

Support preparation of a write-up for the Commerce Business Daily;

Support discusssions with A/Es to clarify technical aspects of the request for proposal;

Participate in board discussions with candidate A/Es for further evaluation of qualifications;

Technically support contract negotiations and resolve any misconceptions;

Provide necessary documentation for start of efforts by the $A / E$ dind revise work statement to reflect any negotiated agreements with the $A / E$.

Meteorological station data will be gathered to support preparation of the environmental report by Pacific Northwest Laboratory Meteorologic Center. 


\section{OBJECTIVE}

The objectives of this activity are to direct, monitor progress, audit, review, and report work performed by the $A / E$ so that the repository conceptual, Titles I and II design, and Title III inspection are in accordance with the approved design criteria.

\section{DESCRIPTION}

Repository design will include the following subactivities.

- Technical management, including all the control systems for monitoring performance within this activity.

- Systems design, including ventilation/cooling, utilities, communication, monitoring and control, fire protection, mine water control, and security.

- Remote handling design, including manipulators, cranes, transporters, and inspection equipment. Remote handling equipment is required for surface and subsurface operations.

- Surface facilities design, including waste handling buildings, maintenance shops, hoist areas, warehouses, and central control building.

- Subsurface facilities design, including emergency, material storage, warehouse, office, and waste storage areas.

- Repository shafts design consisting of waste, ventilation, escape, $\mathrm{man} / \mathrm{material,} \mathrm{and} \mathrm{remote} \mathrm{handling.}$

To complete this work, the following tasks will be performed.

- Work statements will be written.

- Contract direction will be implemented regarding responsibilities and authorities.

- An interface control system will be established and maintained.

- A change control system will be established and maintained.

- Quarterly cost estimate and schedule reviews will be conducted.

- Monthly and quarterly reviews will be prepared and distributed.

- Participation in design reviews will be assured.

- Title I and Title II design will be approved when completed. 
ACTIVITY Repository Design (continued) ACCOUNT CODE L82

- Construction inspection will be conducted and compliance with the approved design will be monitored.

- Liaison with DOE will be provided.

These tasks will be continuously performed during the construction phases. 


\section{OBJECTIVE}

The objective of this activity is to provide technical management for long-lead procurement of the repository.

DESCRIPTION:

Long-lead procurement is the procurement of equipment and services for repository construction that could not be performed by the construction contractor and still maintain the desired construction schedule. This activity includes the long-lead procurement planning, the technical management of the organization assembling the bid package, placing the purchase order, the expediting, receiving, inspecting, and accepting long-lead equipment. Long-lead procurement includes:

- Canister transporters;

- Hot-cel1-type manipulators and cranes;

- Shaft liner/casing;

- Decontamination equipment;

- Overpack equipment;

- Remote handling equipment;

- Special mining equipment and other equipment to be identified during the conceptual and Title 1 design phases. 


\section{OBJECTIVE}

The objective of this activity is to support the efforts of the DOE Construction Manager Selection Board in selecting a qualified CM for the construction of a basalt waste repository.

DESCRIPTION:

In order to support the efforts of the CM Selection Board, the following: efforts will be required:

- Provide technical assistance to the board;

- Aid in preparing a write-up for the Commerce Business Daily;

- Support discussions will be held as necessary with CMs to clarify technical aspects of the request for proposal;

- Participate in discussions with candidate CMs for further evaluation of qualifications;

- Technically support contract negotiations and resolve any misconceptions;

- Provide necessary documentation for start of effort by CM and revise work statement to reflect any negotiated agreements with the CM. 


\section{OBJECTIVE}

The objectives of this activity are to direct, monitor progress, audit, review, and report work performed by the construction manager so that the repository is constructed in accordance with the approved design.

\section{DESCR IPTION}

The construction technical management will oversee construction of the following portions of the repository.

- Systems, including ventilation/cooling, utilities, communication, monitoring and control, fire protection, mine water control, and security.

- Surface and subsurface facilities, including waste handling buildings, maintenance shops, hoist areas, warehouses, central control buildings, emergency, material storage, warehouse, office, and waste storage areas.

- Remote handling, including cranes, transporters, and manipulators.

- Repository shafts, including ventilation and escape, man/material, and remote handling.

Technical management will perform the following tasks.

- Assure contract direction is clearly understood for responsibilities and authorities.

- Establish and maintain an interface controi system.

- Establish and maintain a change control system.

- Provide procurement services and/or review procurement actions.

- Conduct quarterly cost estimate and schedule reviews.

- Prepare and distribute monthly and quarterly reports.

- Participate in final inspection and testing and accept complete facilities for operation.

- Assure completion of as-built drawings and quality records.

- Provide liaison with DOE. 


\section{OBJECTIVE}

The objective of Site-Specific Tests is to verify that the properties of basalt at the specific repository site are comparable to those obtained at the NSTF.

\section{DESCR IPTION}

Once a site is selected and an SCR transmitted to the NRC, additional site-specific tests may be determined to be desirable. These tests would serve to clearly define the envelope of site-specific underground properties that can not be obtained from the surface or through the use of drill holes.

Possible objectives would be to:

- Verify that a large diameter shaft can be economically drilled in Columbia River Básalt utilizing existing technology.

- Provide access for measuring in situ vertical and horizontal stresses.

- Provide direct access to the host rock for development and evaluation of remote sensing geophysical techniques.

- Provide an access for in situ verification for a borehole plugging demonstration.

- Provide access for determining in situ vertical permeabilities within the host rock.

- Demonstrate our ability to isolate aquifers from each other and from the shaft by use of inspection ports.

- Evaluate the degreee and type of fracturing induced by drilling of the shaft for design of borehole plugging seals.

- Verify the degree of fracturing in the host rock.

- Obtain ground-water samples directly from individual aquifers which are more representative than samples obtained from small diameter holes.

- Verify the three-dimensional spatial distribution of sécondary minerals within lie host rock.

- Establish baseline penetration rates in Columbia River Basalt that can be extrapolated to larger diameter shafts.

- Determine the type of drilling fluid required to control ground-water movement in all aquifers to the zone of interest. 


\section{SCHEDULE}

Schedules for the project are developed in critical path method (CPM) format and portrayed in time scale. The project critical path is determined as the longest sequential path of activities which paces completion of the project. The schedules are constructed in three levels.

\section{A. PROJECT PHASING PLAN (Major Project Milestones)}

The Project Phasing Plan (Figure 5.1) illustrates the established baseline program and contains items originally identified by DOE and Rockwell as critical to the success of the project. The Project Phasing Plan is controlled by DOE-RL. Their approval, with concurrence of DOE-HQ, is required before any major project milestones can be changed. The major project milestones are listed in Table 5.1. These are DOE-HQcontrolled milestones.

\section{B. MASTER PROJECT SCHEDULE (Key Milestones)}

The Master Project Schedule (Figure 5.2) presents all contractual and internal milestones identified by program management as critical to the success of the project. The Master Project Schedule is controlled by the Project Director. Concurrence of DOE-RL is required for any changes to the Master Project Schedule affecting key milestones. The key milestones are listed in Table 5.2. These are DOE-RL-controlled milestones.

\section{END FUNCTION OPERATING SCHEDULES (Activity Nodes)}

A Master Operating Schedule is prepared for each end function and the activity nodes provide the basis for the preparation of the work package authorizations and commitments. Control of the activity nodes within the End Function Master Operating Schedule is the responsibility of the end function manager. Approval of the End Function Manager is required to change any activity node.

\section{SCHEDULE LOGIC}

The overall program schedule is divided into phases as shown in Figure 5.3. Prior to repository operations, there are 6 phases and 6 possible rejection steps. The last 2 phases and rejection steps involve the NRC. The program schedules presented in this program plan precede the logic of Figure 5.3. The base program, as depicted in this figure and the other figures, requires a total of 15 years under optimum circumstances. Additional research and development and 1 icensing requirements and potential construction delays could affect the schedule by as much as 10 years.

\section{E. MANAGEMENT COMMITMENTS}

In addition to the preceding noted milestones (Tables 5.1 and 5.2 ), the following activities will be performed by the BWIP.

- Revise and update this technical program plan on an annual basis; 


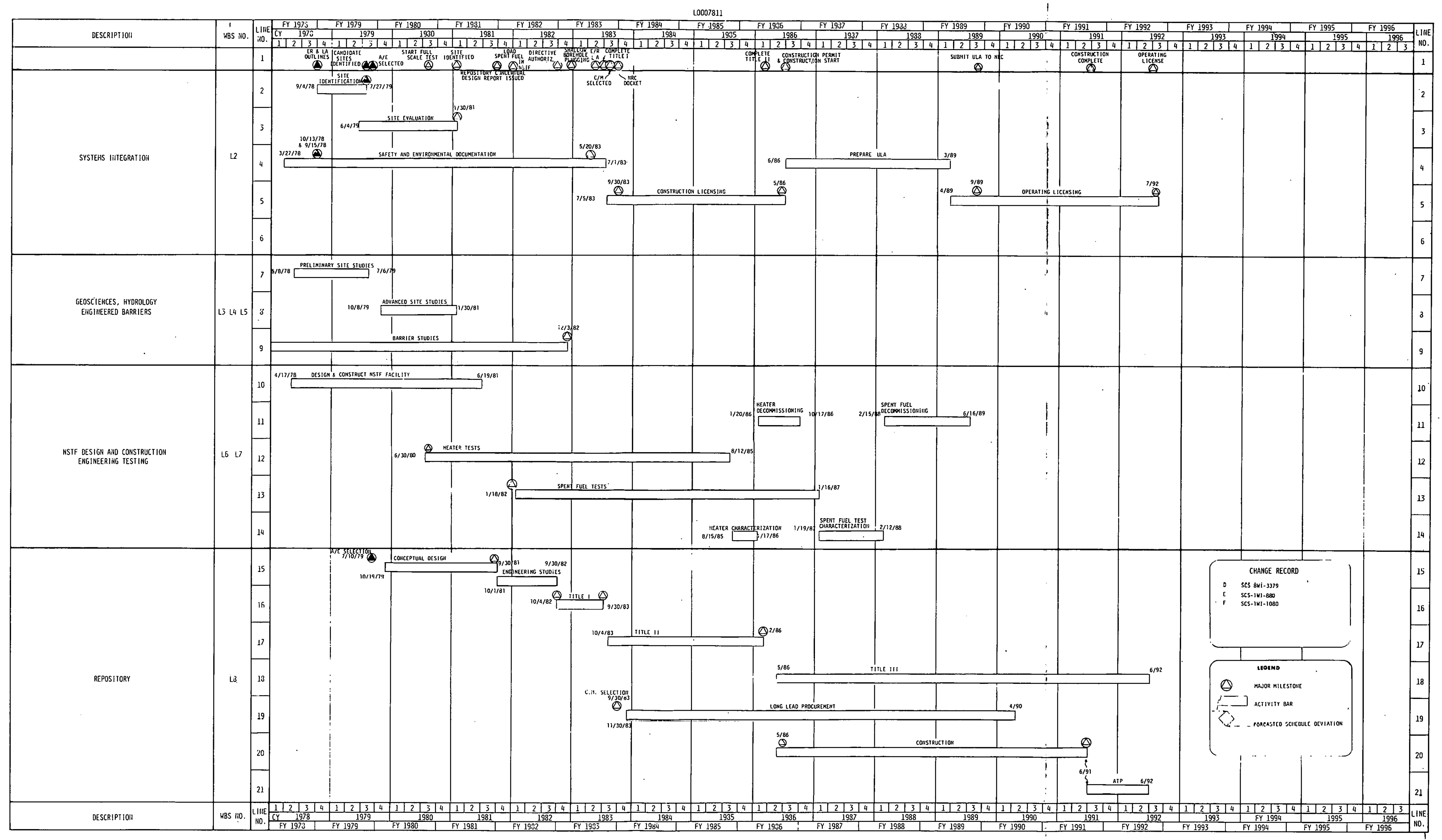




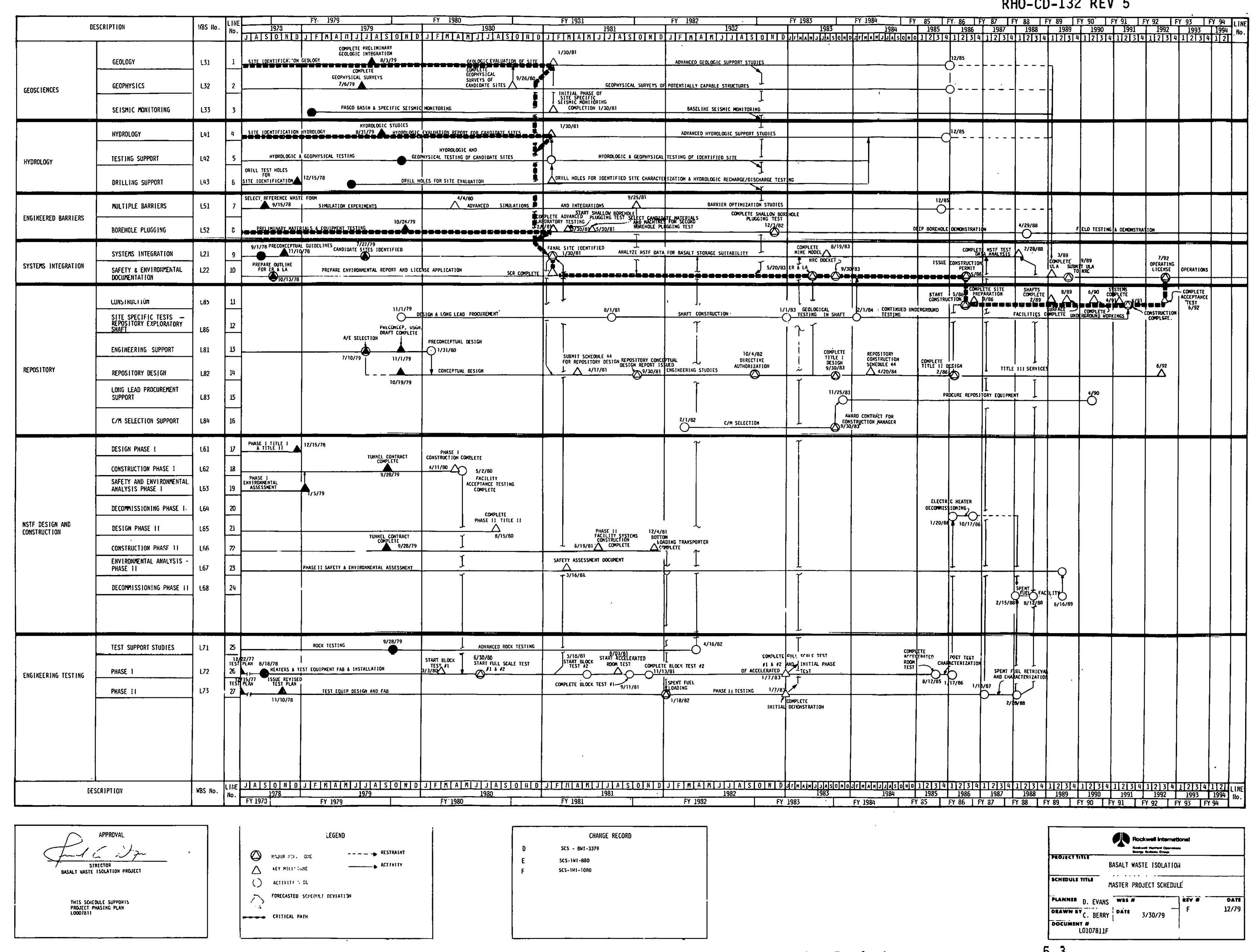

FIGURE 5.2. Master Project Schedule--Basalt Waste Isolation Project. 


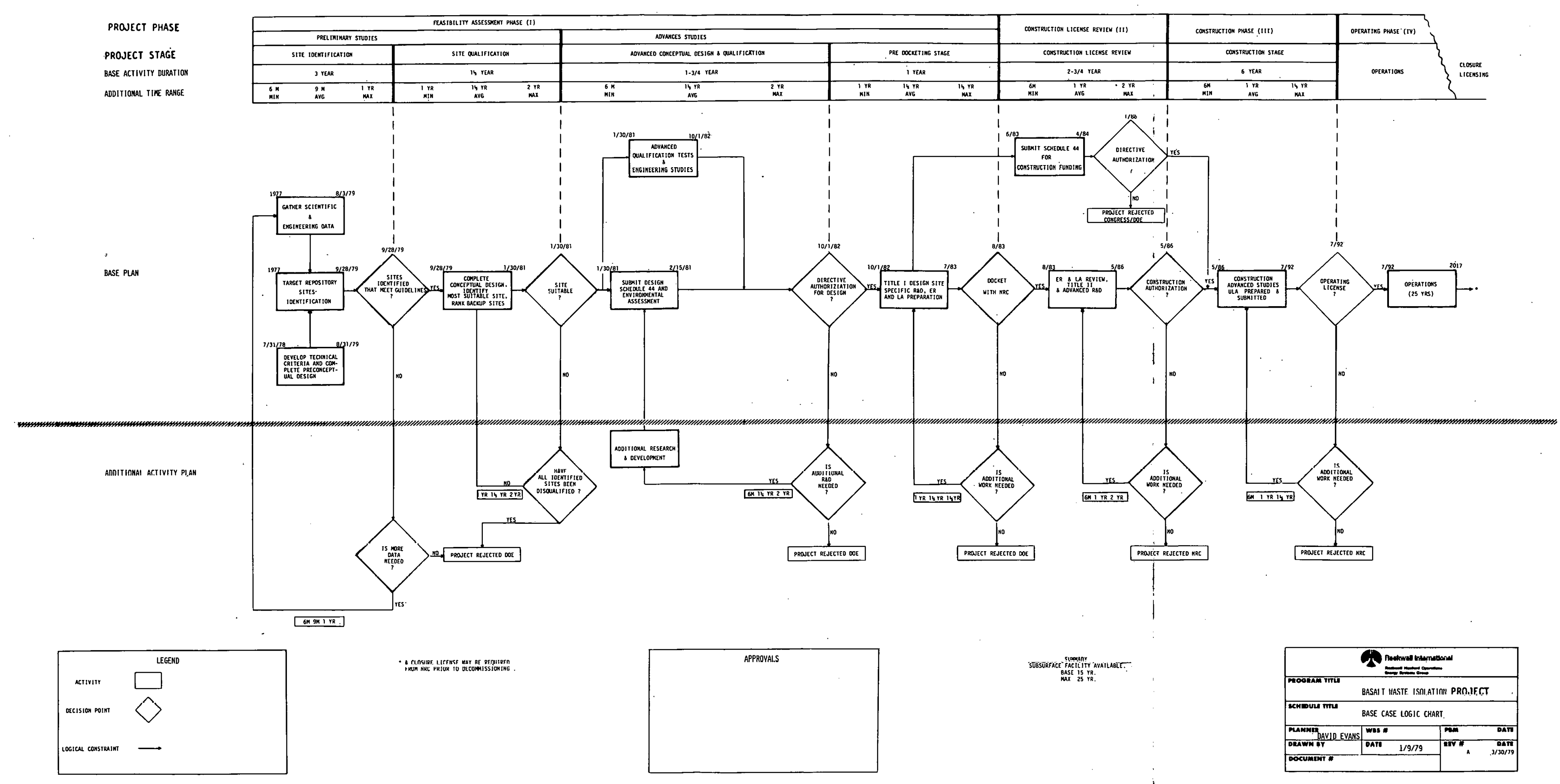


TABLE 5.1. Major Program Milestone Description--Basalt Waste Isolation Project.

\section{Major Milestone Description}

Outline of the ER and LA Proposal Prepared

Candidate Repository Sites Identification Complete

Repository A/E Selection Complete

Start NSTF Phase I First and Second Full-Scale Tests

Final Repository Site Identification Complete

Repository Conceptual Design Report Issued

Load the First Spent Fuel Canister in NSTF

*Receive Directive Authorization for Zepository Design

\section{Shallow Borehole Plugging Test Complete}

*ER and LA Complete

«Repository Title I Design Complete

*Award Repository Construction Manager Contract

$+\star$ Docket LA--NRC

*Repository Title II Design Complete

$+*$ Issue Repository Construction Authorization--NRC

* Start Construction on Repository Site. Preparation

\begin{tabular}{|c|c|c|}
\hline Activity Node & Due Date & Completed \\
\hline L223005 & $10 / 13 / 78$ & $10 / 13 / 78$ \\
\hline L221005 & $09 / 15 / 78$ & $09 / 15 / 78$ \\
\hline L213080 & $07 / 27 / 79$ & \\
\hline L812005 & $09 / 30 / 79$ & $07 / 10 / 79$. \\
\hline $\begin{array}{l}\text { L727050 } \\
\text { L727055 }\end{array}$ & $06 / 30 / 80$ & \\
\hline L213095 & $01 / 30 / 81$ & \\
\hline L821014 & $09 / 30 / 81$ & \\
\hline L737010 & $01 / 18 / 82$ & \\
\hline L821008 & $10 / 01 / 82$ & \\
\hline L523035 & $12 / 03 / 82$ & \\
\hline $\begin{array}{l}\text { L223070 } \\
1075\end{array}$ & $05 / 20 / 83$ & \\
\hline L821010 & $09 / 30 / 83$ & \\
\hline L841070 & $09 / 30 / 83$ & \\
\hline L221085 & $09 / 30 / 83$ & \\
\hline L821015 & $02 / 86$ & \\
\hline L221115 & $05 / 86$ & \\
\hline L853045 & $05 / 86$ & \\
\hline
\end{tabular}


Table 5.1 (continued)

\section{Major Milestone Description}

+*Submit Updated LA to NPC

*Complete Installation of Remote Handling Equipment

+*Issue Repository Operating License--NRC

\begin{tabular}{|c|c|c|}
\hline Activity Node & Due Date & Completed \\
\hline L2222010 & $09 / 89$ & \\
\hline L855030 & $06 / 91$ & \\
\hline$L 222025$ & $07 / 92$ & \\
\hline
\end{tabular}

Activity Node Due Date Completed

*These milestones are subject to the federail government committing to a decision to proceed with a repository in basalt. + DOE or NRC milestones.

G 
TABLE 5.2. Key Milestones--Basalt Waste Isolation Project.

\section{Milestone Description}

NSTF Phase II Test Plan Complete

NSTF Phase I Test Plan Complete

Reference Waste Forms Selected for Waste-Basalt

Interaction Studies

*outline of the ER and LA Proposal Prepared

Issue Repository Preconceptual Desigr Guidelines

Issue Revised NSTF Phase II Test Plar:

Complete Core Drilling DC-2 and DC-4

vi Complete NSTF Phase I, Title II Design

+Comple ¿e Environmental Assessment for NSTF Phase I \& Phase II

Complete Pasco Basin Magnetotelluric Survey Report

Complete Pasco Basin Aeromagnetic Survey Report

Complete Pasco Basin Seismic Survey Preliminary Report

Complete Geophysical Study of Specific Structures Report

* Candidate Repository Sites Identification Complete

Complete Preliminary Geologic Integration

Complete Preliminary Hydrologic Studies.

\begin{tabular}{|c|c|c|}
\hline Activity Node & Due Date & Completed \\
\hline L735005 & $12 / 15 / 77$ & $12 / 15 / 77$ \\
\hline L725005 & $12 / 22 / 77$ & $12 / 22 / 77$ \\
\hline L511010 & $09 / 15 / 78$ & $09 / 08 / 78$ \\
\hline $\begin{array}{l}\text { L223005 } \\
\text { L221005 }\end{array}$ & $\begin{array}{l}10 / 13 / 78 \\
09 / 15 / 78\end{array}$ & $\begin{array}{l}10 / 13 / 78 \\
08 / 15 / 78\end{array}$ \\
\hline L211020 & $11 / 10 / 78$ & $11 / 10 / 78$ \\
\hline L735030 & $11 / 22 / 78$ & $11 / 10 / 78$ \\
\hline L431055 & $12 / 15 / 78$ & $12 / 15 / 78$ \\
\hline L615030 & $12 / 15 / 78$ & $12 / 15 / 78$ \\
\hline $\begin{array}{l}\text { L631025 } \\
\text { L672025 }\end{array}$ & $01 / 05 / 79$ & $01 / 05 / 79$ \\
\hline L321070 & $05 / 04 / 79$ & $05 / 15 / 79$ \\
\hline L321100 & $06 / 08 / 79$ & $06 / 08 / 79$ \\
\hline L.321030 & $07 / 06 / 79$ & $06 / 15 / 79$ \\
\hline L321110 & $07 / 06 / 79$ & $07 / 01 / 79$ \\
\hline L213080 & $07 / 27 / 79$ & \\
\hline L311040 & $08 / 03 / 79$ & $08 / 01 / 79$ \\
\hline L411035 & $08 / 31 / 79$ & $09 / 14 / 79$ \\
\hline
\end{tabular}


Table 5.2 (continued)

Milestone Description

NSTF Tunnel Contract Complete

*Repository A/E Selection Complete

Start Repository Conceptual Design

Complete Borehole Plugging Materials and Equifment Testing

DOE Approval of Complete Repository Precorceptual [iesign

Start NSTF Block Test No. 1

Complete Integration of Waste-Basalt Interaction Tests \&

Submit Preliminary Engineered Barriers Integration Report to Project Director

$\underset{\infty}{\infty}$ NSTF Phase I Construction Complete

*Start NSTF Phase I First and Second FuTl-Scale Tests

NSTF Phase II, Title II Complete

Complete FY 1980 Geophysical Surveys and Studies of Specific Structures That Could Affect the Candidate Repository Site

Complete Site Characterizaticn Report

Initial Phase of Site-Specific Seismic Monitoring Completed

Complete Final Geologis Site Evaluation

*Final Repository Site ]dentification Complete

\begin{tabular}{|c|c|c|}
\hline Activity Node & Due Date & Completed \\
\hline $\begin{array}{l}\text { L661025 } \\
\text { L621010 }\end{array}$ & $09 / 28 / 79$ & $09 / 28 / 79$ \\
\hline L812005 & $09 / 30 / 79$ & $07 / 10 / 79$ \\
\hline L82100: & $10 / 19 / 79$ & $10 / 19 / 79$ \\
\hline L521050 & $10 / 26 / 79$ & $08 / 01 / 79$ \\
\hline L811060 & $11 / 01 / 79$ & \\
\hline L725065 & $03 / 30 / 80$ & \\
\hline L512025 & $04 / 04 / 80$ & \\
\hline L625075 & $04 / 11 / 80$ & \\
\hline $\begin{array}{l}L 727050 \\
L 727055\end{array}$ & $06 / 30 / 80$ & \\
\hline L654175 & $08 / 15 / 80$ & \\
\hline $\begin{array}{l}\text { L321040 } \\
\text { L321120 }\end{array}$ & $09 / 26 / 80$ & \\
\hline $\begin{array}{l}\text { L221035 } \\
\text { L223035 }\end{array}$ & $01 / 30 / 81$ & \\
\hline $\begin{array}{l}\text { L331010 } \\
\text { L331015 }\end{array}$ & $01 / 30 / 81$ & \\
\hline L311105 & $01 / 30 / 81$ & \\
\hline L213095 & $01 / 30 / 81$ & \\
\hline
\end{tabular}




\section{Milestone Description}

Complete Hydrologic Report for Final Site Evaluation

Drill and Test for Hydrologic Discharge/Recharge,

Deep Hydrology, and Pasco Bas in Geology

Start NSTF Phase I Tests

+NSTF Phase II Safety Assessment Document DOE Review and Approval

start Shallow Borehole Plugging Test

Prepare Schedule 44 for Repository Design for DOE-RL

select Candidate Materials and Machines for Second Borehole

Plugging Test

io

NSTF Phase II Facility Systems Construction Complete

Start NSTF Phase I Accelerated Room Test

Complete Advanced Waste-Basalt Interaction Simulations and Tests Integration

*Repository Conceptual Design Report Issued

Complete BLT

*Load the First Spent Fuel Canister in NSTF

$+\star \star R e c e i v e$ Directive Authorization for Repository Design

*Shallow Borehole Plugging Test Complete

\begin{tabular}{|c|c|c|}
\hline Activity Node & Due Date & Completed \\
\hline L411075 & $01 / 30 / 81$ & \\
\hline L431110 & $01 / 30 / 81$ & \\
\hline $\begin{array}{l}\text { L727050 } \\
\text { L727055 }\end{array}$ & $06 / 30 / 80$ & \\
\hline L672025 & $03 / 16 / 81$ & \\
\hline L523035 & $03 / 30 / 81$ & \\
\hline L821006 & $04 / 17 / 81$ & \\
\hline L521060 & $05 / 30 / 81$ & \\
\hline L663070 & $06 / 19 / 81$ & \\
\hline L727060 & $08 / 03 / 81$ & \\
\hline L513070 & $09 / 25 / 81$ & \\
\hline L821014 & $09 / 30 / 81$ & \\
\hline L664100 & $12 / 04 / 81$ & \\
\hline L737010 & $01 / 18 / 82$ & \\
\hline L821008 & $10 / 01 / 82$ & \\
\hline L523035 & $12 / 03 / 82$ & \\
\hline
\end{tabular}

*Major milestones

$\star \star$ This and all following milestones are subject to the federal government committing to selecting a basalt repository

$+D O E$ or NRC milestones 
Table 5.2 (continued)

\section{Milestone Description}

Complete Full-Scale Tests \#s 1 and 2 and Initial Phase of Accelerated Test

*ER and LA Complete.

Complete Initial Demonstration of Phase II Testing

Complete Mine Model Cades

*Repository Title I Design Conplete

+*Award Repository Construction Manager Contrazt

*Docket License Application--NRC

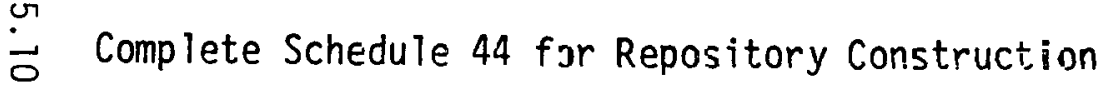

*Repository Title II Design Complete

$+\star$ Issue Repository Construction Authorization--MRC

*Start Construction on Rejository Site Preparation

Complete Repository Site Preparation

Complete Analys is of NSTF Test Data

Complete Repository Shafts

Complete Repository Updated LA

Complete Repository Surface Facilities
Activity Node Due Date Completed

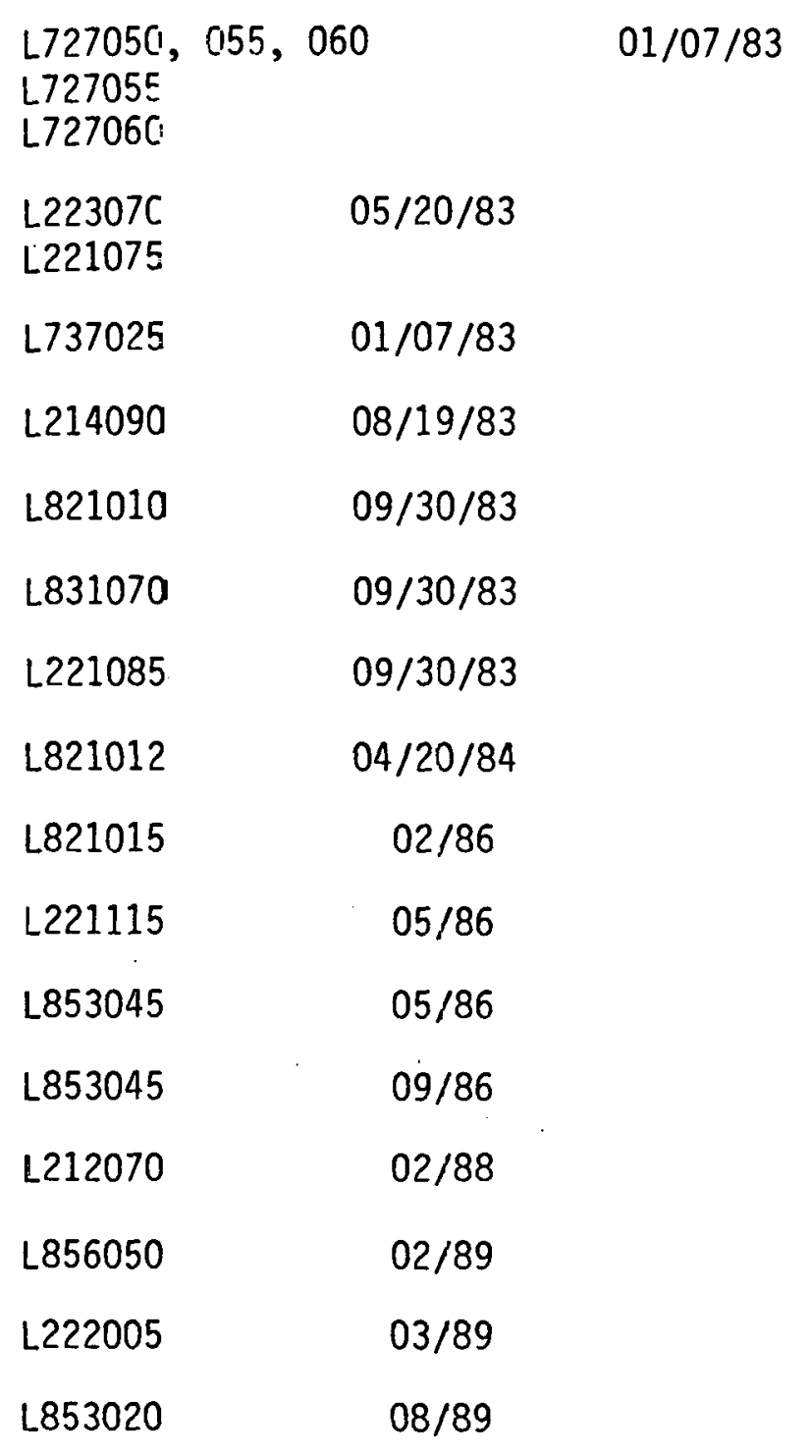


Table 5.2 (continued)

\section{Milestone Description}

+*Submit Updated LA to NRC

Complete Repository Underground Workings

Complete Installation of Repository Systems

*Complete. Installation of Remote Handling Equipment, Repository Construction Complete

Complete Repository Title III

Complete Repository Acceptance Testing

+*Issue Repository Operating License--NRC

\begin{tabular}{cc} 
Activity Node & $\frac{\text { Due Date }}{\text { Completed }}$ \\
\hline L222010 & $09 / 89$ \\
L854025 & $06 / 90$ \\
L852010 & $04 / 91$ \\
L855030 & $06 / 91$ \\
L821020 & $06 / 92$ \\
L851020 & $06 / 92$ \\
L222025 & $07 / 92$
\end{tabular}

$\stackrel{\nu}{\beth}$

*Major milestones

$+D O E$ or NRC milestones 
- Issue quarterly technical reports;

- Issue an annual technical report;

- Maintain an up-to-date quality assurance program plan;

- Procure and manage subcontracted effort as required to support the goals of the project;

- Maintain a data storage system which meets the requirements of 10 CFR 60 ;

- Overview comnittees for geology, hydrology, and rock mechanics are composed of distinguished members from the academic community, the U.S. Geological Survey, and State of Washington Departments of Natural Resources and Ecology; critical reviews and documented findings of Rockwell reports and scheduled meetings in each discipline will be conducted two to four times each year; a committee report on each meeting will be sent to DOE;

- Continue to prepare and submit monthly status reports to DOE and conduct monthly status briefings for appropriate DOE personnel. 


\section{RESOURCE REQUIREMENTS}

BUDGET

This section provides the total budget requirements to accomplish the BWIP objectives and goals as defined in this technical program plan.

1. Summary Budget

The BWIP budget is summarized in Table 6.1 for FY's 1980 through 1986 . The expense budget increases from $\$ 30$ million in FY 1979 to $\$ 34.5$ million in 1980. This reflects the resumption of the core hole drilling and the start of conceptual design by the A/E. The NSTF design and construction will be funded through a capital line item beginning in FY 1980. The funding source for the potential exploratory shaft has not been determined.

\section{Expense Budget}

Table 6.2 details the expense budget for FY's 1980 and 1981 .

3. Capital Equipment

Table 6.3 details capital equipment for FY'S 1980 and 1981. 
TABLE E.1 Sunmary Budget--Basalt Waste Isolation Project

(Dollars in Thousands)

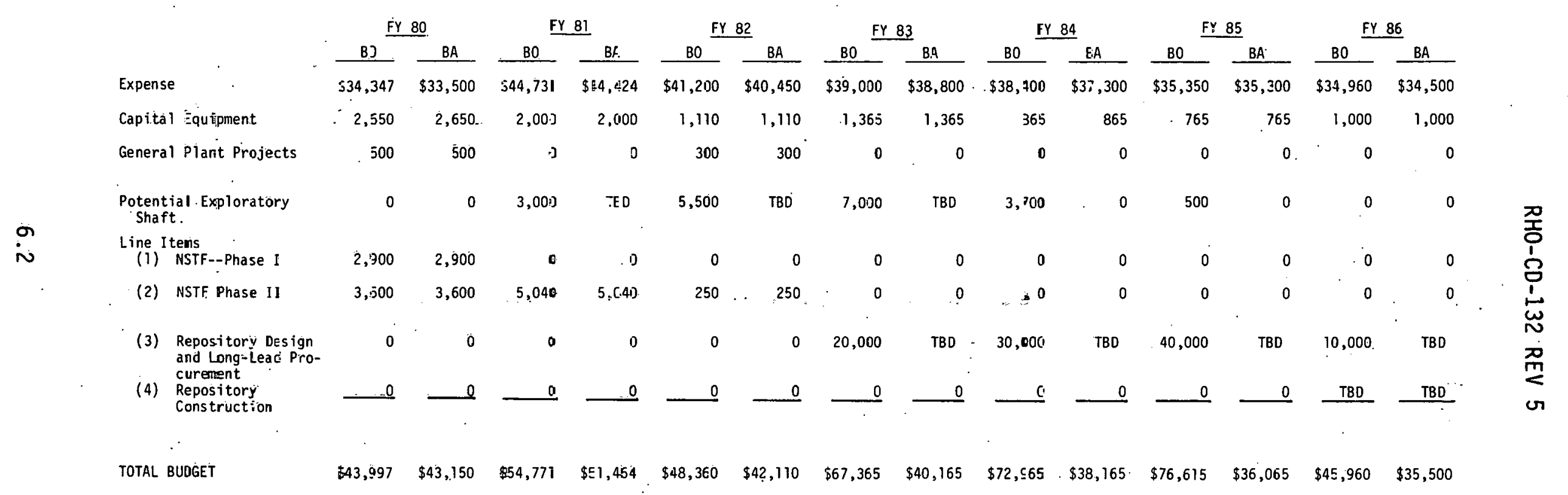


TAB́LE 6.2. Expense Requirements--Basalt Waste Isolation Project.

(Budget outlay; dollars in thousands)

\begin{tabular}{|c|c|c|c|c|c|c|c|c|c|}
\hline $\begin{array}{l}\text { End } \\
\text { Function }\end{array}$ & $\begin{array}{l}\text { Activity } \\
\text { Number } \\
\end{array}$ & Activity Description & $\begin{array}{c}F Y \\
1980 \\
\end{array}$ & $\begin{array}{c}\text { FY } \\
1981 \\
\end{array}$ & $\begin{array}{c}F Y \\
1982 \\
\end{array}$ & $\begin{array}{c}\mathrm{FY} \\
1983 \\
\end{array}$ & $\begin{array}{c}\mathrm{FY} \\
1984 \\
\end{array}$ & $\begin{array}{c}F Y \\
1985 \\
\end{array}$ & $\begin{array}{c}\mathrm{FY} \\
1986 \\
\end{array}$ \\
\hline \multirow[t]{2}{*}{ LI } & & Project Managenent and Support & & & & & & & \\
\hline & $\begin{array}{l}\text { LI1 } \\
\text { L12 } \\
\text { L13 } \\
\text { L15 }\end{array}$ & $\begin{array}{l}\text { Project Managenent } \\
\text { Program Control } \\
\text { Qual ity Assurance } \\
\text { Data Management }\end{array}$ & $\begin{array}{r}840 \\
868 \\
538 \\
555 \\
\end{array}$ & $\begin{array}{r}1,160 \\
945 \\
580 \\
590 \\
\end{array}$ & & & & & \\
\hline . & & TOTAL & $\$ 2,801$ & $\$ 3,275$ & $\$ 4,566$ & $\$ 5,007$ & $\$ 5,004$ & $\$ 4,989$ & $\$ 5,000$ \\
\hline \multirow[t]{2}{*}{ L2 } & & Systems Integration & & & & & & & \\
\hline & $\begin{array}{l}\mathrm{L} 20 \\
\mathrm{~L} 21 \\
\mathrm{~L} 22\end{array}$ & $\begin{array}{l}\text { Project Management } \\
\text { Systems Integration } \\
\text { Safety and Environmental Docum. }\end{array}$ & $\begin{array}{r}32 \\
1,745 \\
2,087 \\
\end{array}$ & $\begin{array}{r}.75 \\
2,266 \\
2,801 \\
\end{array}$ & . & & & & \\
\hline : & & TOTAL & $\$ 3,864$ & $\$ 5,142$ & $\$ 6,185$ & $\$ 7,200$ & $\$ 8,100$ & $\$ 8,900$ & $\$ 9,800$ \\
\hline \multirow[t]{3}{*}{ L3 } & & Geosciences & & . & & & & & \\
\hline & $\begin{array}{l}\text { L30 } \\
\text { L31 } \\
\text { L32 } \\
\text { L33 }\end{array}$ & $\begin{array}{l}\text { Project Managenent } \\
\text { Geology } \\
\text { Geophysics } \\
\text { Seismic Monitoring }\end{array}$ & $\begin{array}{r}164 \\
3,259 \\
1,416 \\
307 \\
\end{array}$ & $\begin{array}{r}325 \\
2,810 \\
2,281 \\
685 \\
\end{array}$ & $\cdot$ & $\square$ & $\ldots$ & & \\
\hline & & TOTAL & $\$ 5,146$ & $\$ 6,101$ & $\$ 6,128$ & $\$ 4,700$ & $\$ 4,200$ & $\$ 3,700$ & $\$ 3,200$ \\
\hline \multirow[t]{3}{*}{ L4 } & . & Hydrology & & & & & & & \\
\hline & $\begin{array}{l}L 40 \\
L 41 \\
L 42 \\
L 43\end{array}$ & $\begin{array}{l}\text { Project Management } \\
\text { Hydrology } \\
\text { Testing Support } \\
\text { Drilling Support }\end{array}$ & $\begin{array}{r}77 \\
1,451 \\
2,502 \\
2,493 \\
\end{array}$ & $\begin{array}{r}116 \\
1,392 \\
2,910 \\
5,278 \\
\end{array}$ & & & & & 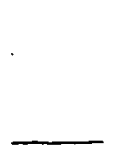 \\
\hline & & TOTAL & $\$ 6,523$ & $\$ 9,696$ & $\$ 9,363$ & $\$ 9,800$ & $\$ 7,800$ & $\$ 5,700$ & $\$ 4,800$ \\
\hline
\end{tabular}


Table 6.2 (continued)

\begin{tabular}{|c|c|c|c|c|c|c|c|c|c|}
\hline $\begin{array}{c}\text { End } \\
\text { Function }\end{array}$ & $\begin{array}{l}\text { Activity } \\
\text { Number }\end{array}$ & Activity Description & $\begin{array}{c}F Y \\
1980 \\
\end{array}$ & $\begin{array}{r}F y \\
1981 \\
\end{array}$ & $\begin{array}{c}\mathrm{FY} \\
1982 \\
\end{array}$ & $\begin{array}{r}F Y \\
-983 \\
\end{array}$ & $\begin{array}{c}F Y \\
1984 \\
\end{array}$ & $\begin{array}{c}\mathrm{FY} \\
1985 \\
\end{array}$ & $\begin{array}{c}F Y \\
1986 \\
\end{array}$ \\
\hline L5 & & Engineered Barriers & & & & & & & \\
\hline & 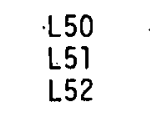 & $\begin{array}{l}\text { Project Mariagement } \\
\text { Multiple Barriers } \\
\text { Borehole Plugging }\end{array}$ & $\begin{array}{r}161 \\
2,642 \\
1,007 \\
\end{array}$ & $\begin{array}{r}179 \\
4,320 \\
2,479 \\
\end{array}$ & & & & - & \\
\hline & & TOTAL & $\$ 3,810$ & $\$ 5,978$ & $\$ 8,821$ & $\$ 8: 188$ & $\$ 9,075$ & $\$ 7,670$ & $\$ 8,710$ \\
\hline
\end{tabular}

L6

NSTF-Design \& Construction

\section{Project Management}

Design--Phase I

Construction--Phase

Safety \& Erv. Analysis--Piase 1

Decommissioning--Phase I

Design--Fhase II

Construction--Phase II

Safety \& Env. Analysis--Phase II

Decommissioning--Phase II

$$
\text { TOTAL }
$$

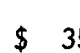

\section{Engineering Testing}

Project Management

Engirieering Studies

Phase I

Phase II

TOTAL

$\begin{array}{rrr}159 & & 175 \\ 16 & \\ 120 & \\ 16 & & 17 \\ & \\ 216 & & 118 \\ 92 & & 180 \\ 91 & & 101 \\ -\$ 710 & \$ 591\end{array}$

17

180

591

$\$ 350$

$\$ 600$

$\$ 800$

$\$ 600$

$-0-$

\section{Repository}

Project Management

Engineering Support

Repository Design

Long-Lead Procurement suppcrt

CM Selection Support

Construction

Site Specific Tests

TOTAL.

TOTAL PROGRAM EXPEVSE BIJDGET

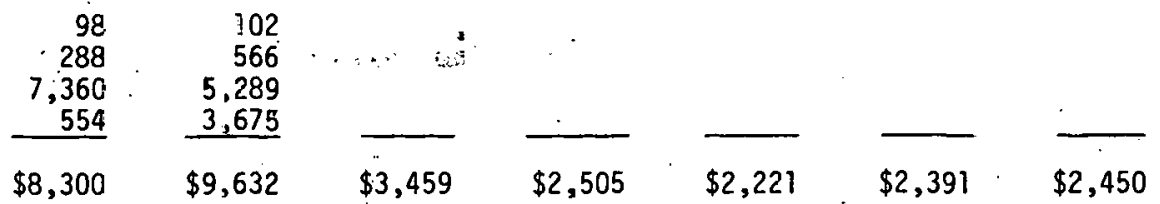

$\begin{array}{rr}237 & 304 \\ 75 & 151 \\ 3034 & 2,861\end{array}$

A/E (Included in Repositcry -otal)

(Included in Repository Tcta ${ }^{\circ}$ )

$\begin{array}{lllllll}\$ 3,346 & \$ 3,316 & \$ 2,328 & \$ 1,000 & \$ 1,, 00 & \$ 1,400 & \$ 1,000 \\ \$ 34,500 & \$ 44,731 & \$ 41,200 & \$ 39,000 & \$ 38,400 & \$ 35,350 & \$ 34,960 \\ \$ 2,600 & \$ 2,200 & \$ 1,200 & & & & \end{array}$


TABLE 6.3. Capital Equipment Not Related to Construction-Basalt Waste Isolation Project.

(Dollars in Thousands)

\section{FY 80}

General Office Equipment

Portable Micro-Seismic Monitoring System

Orthogonal Borehole Seismic Monitoring System

Borehole Geophysical Logging System

Computer Terminal \& Support Hardware

Drilling Equifment:

or

- Drill Rig

- Compressors

- Drill Stem Pipe

Miscellaneous Analytical

Equipment for Waste/Basalt

Interaction

Miscellaneous Operating Equipment

Data Acquisition System Equipment

Geophysical Mcinitoring Equipment for Phase I Heater Test

Miscellaneous Equipment \& Instrumentation

\section{FY 81}

$\$ 25$

100

60

80

100

700

300

150

300

50

200

200

385

TOTAL

General Office Equipment

$\$ 25$

Cross-Hole Geophysical Equipment

Computer Terminal \& Support Hardware

Materials \& Analytical Equipment in Support of Experiments using Radioactive Wastes

Biological Radioactive Monitoring Station

Future Nuclear Waste Test Equipment

Meteorology Station on Repository Site 
7. MANAGEMENT AND CONTROL

\section{A. ORGANIZATION}

The BWIP is managed by DOE-RL. The organizational structure of DOE and the interface with Rockwell as operating contractor are shown in Figure 7.1. Rockwell has been selected by DOE as the operating contractor responsible for the feasibility evaluation of basalt as a repository medium and the techrical management of the design effort and the construction of a repository should feasibility be established. The Rockwell organization is as shown in Figure 7.2. The working organization of the BWIP is shown in Figure 7.3.

The BWIP Director acts as the primary point of contact with the DOE on project activities and is responsible for receiving and approving all correspondence pertaining to prcject activities. In estab?ishing Rockwell's commitments, the BWIP Director will be assisted by the Program Control Manager to assure compliance with the contractual provisions and Rockwell policy. All personnel who are properiy authorized to contact the DOE regarding BWIP activities will consult with the BWIP Director or the BWIP Associate Director in advance of such contacts whenever practical to ensure consistency.

An Associate Director for the BWIP has been appointed to support the BWIP Director. As a member of the Director's Office, he reports to the General Manager, Rockwell Hanford Operations. He is a member of the Executive Staff of the General Manager. He is accountable to the Director for the successful accomplishment of technical objectives, scheduie requirements, and effective technical and cost management. The Associate Director supports the Director as a point of contact with DOE on BWIP activity.

\section{B. ROLE OF ARCHITECT/ENGINEER AND CONSTRUCTION MANAGER}

Both the $A / E$ and the Construction Manager ( $C M)$ contracts are to be direct contracts to DOE with technical management by Rockwell. The A/E will be responsible for the repository design and inspection services during construction. The CM will coordinate all activities during construction.

The A/E will develop conceptual design with an option to continue final design. The conceptual design will be based on preconceptual design, the functions and design criteria, and special studies prepared by Rockwell. The design activities of the $A / E$ will be governed by DOE administrative and Rockwe 11 technical requirements. In addition, the $A / E$. will be required to document the results of conceptual, oreliminary, and final designs using the system design description format. The Rockwell-furnished functions and design criteria will not be changed by the $A / E$ without prior Rockwell approval to ensure control of the design activities. Concurrent with $A / E$ activities, certain special studies will be performed by other subcontractors under direct contract to Rockwell. These special studies are for very specialized technical problems not normally within the expertise of an $A / E$. 


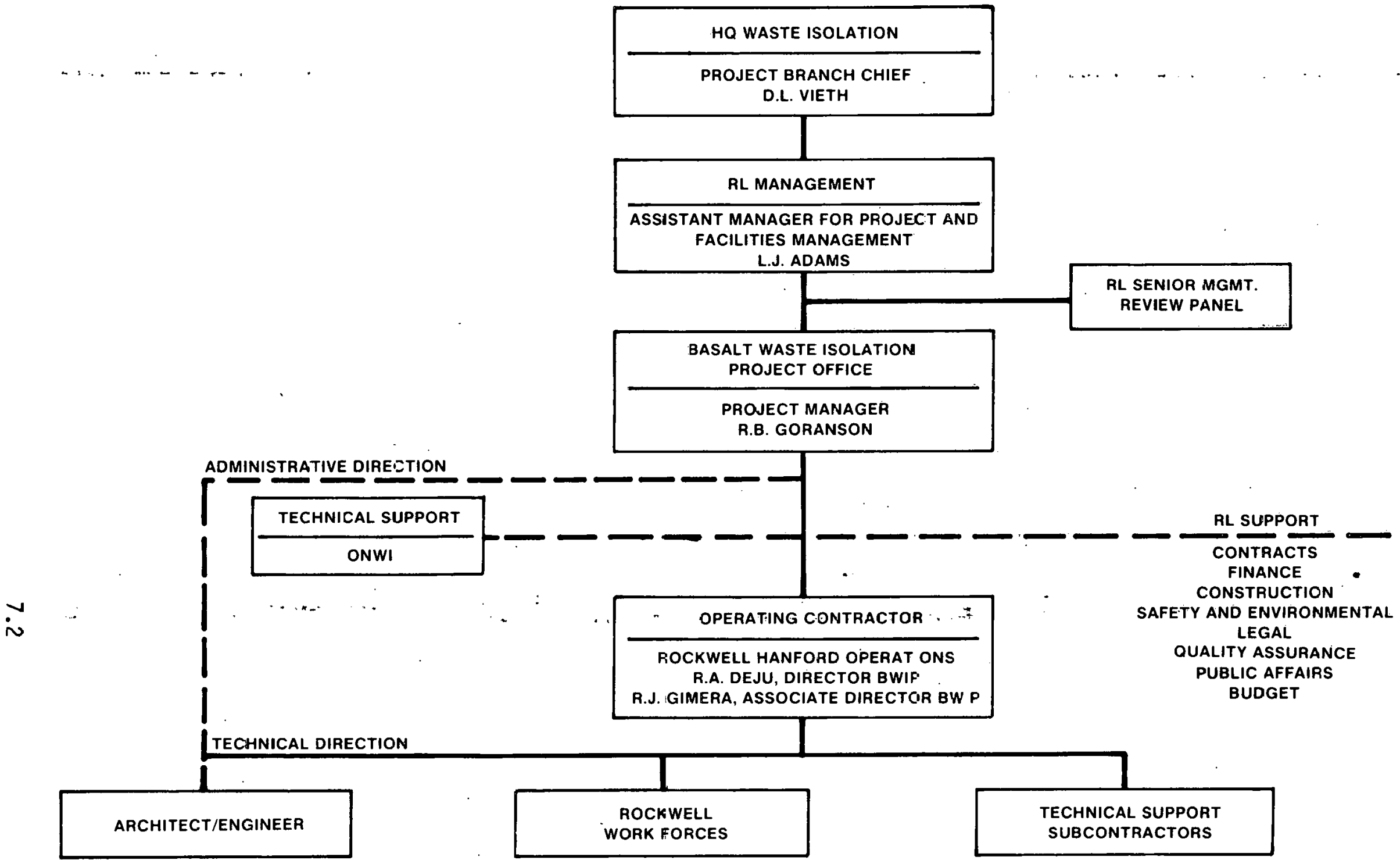

FIGURE 7.1. U.S. Department of Energy Project Management Organization-Basalt Waste Isolation Project. 


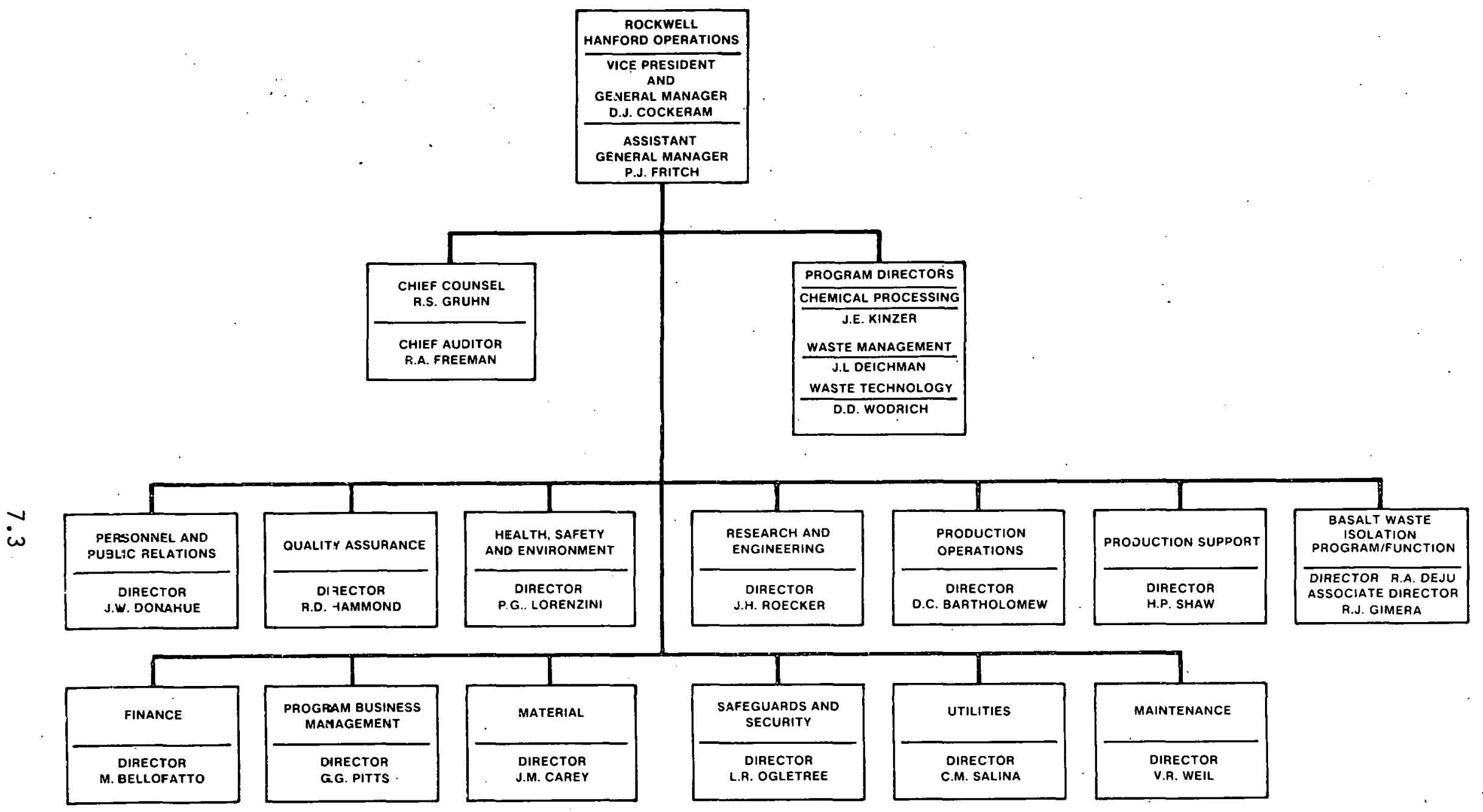

FIGURE 7.2. Rockwell Hanford Operations Organization. 


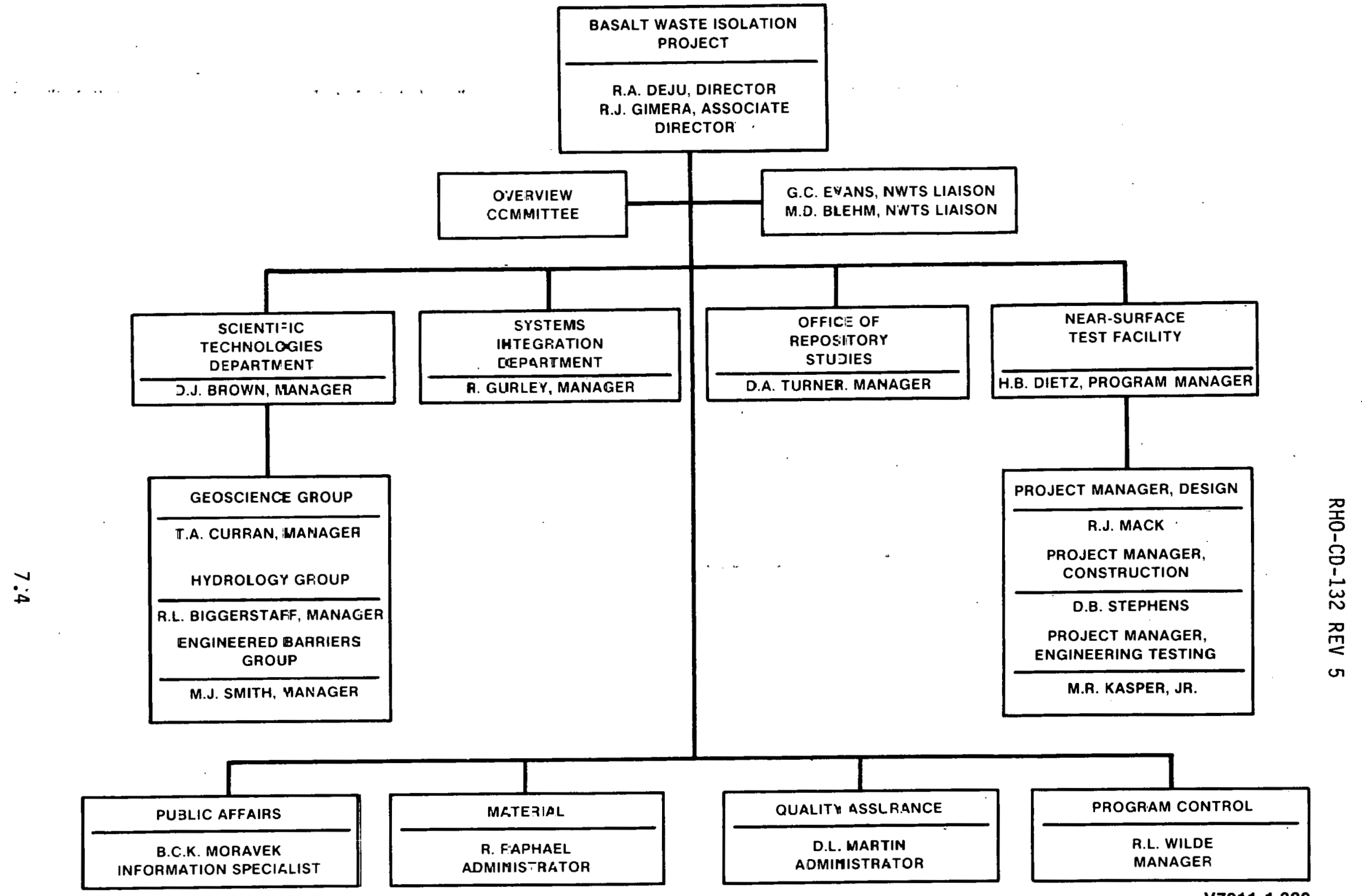

V7911-1.320

FIGJRE 7.3. Horking Organization--Basalt Waste Isolat: an Project. 
At the conclusion of each phase of the design, a detailed technical report containing cost and schedule estimates will be prepared documenting the status of the design at that particuiar time. The results of these various phases of design will be the basis for the ER and safety analysis. Rockwell will prepare the ER and the LAs.

The role of the CM is to prepare bid packages, bid and award the construction contracts, and direct the activities of the contractors. The $C M$ is responsible for integrating the construction work and installing government-furnished equipment. During construction, the $A / E$ will also be required to perform construction inspection services, review the construction. changes, and provide as-bui?t drawings at the completion of the construction activities. At the conclusion of the construction activities, the CM will turn cver a completed facility to Rockwell and $D O E$ in accordance with drawings and specifications prepared by the $A / E$.

A11 work performed by the $A / E$ and the $C M$ will be in accordance with the Rockwell quality assurance progrant plan. Portions of this plan will be imposed on all construction contractors.

\section{SUBCONTRACTORS}

Subcontractors will perform a major portion of the effort required as part of the BWIP. Subcontractors will be technically and administratively managed by Rockwe 11, except for those cases where DOE-RL wili deem it necessary that the contiract be a prime contract to DOE-RL with technical management by Rockwe11. The DOE-managed contracts will inciude and be limited to management of contracts to other governmental agencies, $A / E$ work, and construction work. The purchase order, consultant agreement, or other contractual document entered into between Rockwell and a subcontractor or between DOE and a contractor will form the basis of program performance evaluation for the subcontract. Within 30 days of contract initiation, all subcontractors will be required to submit an organizational structure for the project being contracted. Reviews of the subcontracts wili be performed as per Section D of this chapter. Subcontractors who, in turn, have second and third tiers of subcontracts will also be required to submit appropriate organizational structures covering those tiers.

\section{MANAGEMENT REVIEWS OF INDIVIDUAL PROJECTS}

Reviews of each end function will be conducted by management on a monthly basis. These reviews cover the technical aspects of each project on a work package-by-work package basis and will emphasize problem areas and areas where milestones may be missed or where accomplishments may be delayed. These reviews will be presented to the BWIP Director by the responsible managers and will include presentations by members of participating functional organizations. Technical reviews of individual subcontractors of major importance will be scheduled throughout the year by the Director. 


\section{E. MANAGEMENT REVIEWS OF COST AND SCHEDULE}

In parallel with the technical reviews of each project management reviews of cost and schedules will be conducted. These reviews will be headed by the BWIP Director and will be presented by the responsible manager. The reviews will be conducted in conjunction with the technical reviews. Specific reviews of cost and schedule of major subcontracts will be conducted in conjunction with corresponding technical reviews of these subcontracts.

\section{F. OPERATING COST CONTROL}

Rockwell plans, budgets, authorizes, and controls programmatic work through the use of work packages as described in existing Rockwell guides. Work packages are issued for each subactivity in the WBS and define the work to be accomplished, establish schedules with milestones, and identify the resources to be used. The work package resource allocation is entered into the Rockwell computerized cost accounting system and forms the basic budget against.which the program performance is measured.

The computerized cost accounting system issues a monthly cost report which compares the current month's cost with the budget and the fiscal year-to-date cost with the budget. The report is issued for each work package and is detailed by account class providing immediate identification of any problem accounts. The computerized cost accounting system also provides cost versus budget data for each functional group that supports the program.

Cost reviews are held monthly within Rockwell at the Executive Control Meetings. Functional Directors and Program Directors review each program once per month including an analysis of costs performance in accordance with established Rockwell policies.

Subcontractors provide a significant amount of the work nn the program and, therefore, account for a large part of the cost. Each subcontractor is required to submit a monthly report which provides the same data as the Rockwell monthly report to DOE. One phase of that report is an analysis of cost and an estimate of costs to complete the task. In addition to the monthly report, subcontractors will be audited on a periodic basis as to both cost and schedule performance. When deemed necessary, subcontractors are asked to present, on a formal basis, the financial status of their program.

\section{G. CAPITAL COST CONTROL}

Rockwell plans, budgets, and allocates capital equipment in accordance with established Rockwe1l policies. The Capital Committee controls the purchase and use of all capital equipment. The Director, BWIP, must approve all capital expenditures. 
Capital costs and commitments are reported monthiy by the property control organization. This status report is used by the BWIP to maintain cognizance of the capital resources available to support the program. The property control organization maintains the inventory of capital equipment.

\section{H. PROGRAM PERFORMANCE CONTROL}

The basic controlling structural arrangement for project performance is the WBS as shown in Chapter 4 . Work packages will be issued by the BWIP for each subactivity on the WBS. Individual work package milestones will be consistent with the objectives and schedules of ihe overall master plan shown in Chapter 5 . Each work package issued to a functional organization will contain a description of the work to be done with detailed milestones and specific resource allocations.

The overall performance measurements system will be based on a milestone accountability system stemming from the work out lined in individual work package. Activity networks will be used in a continuing effort as the basis for determining the impact of alternative schedules, deiays in completion of particular tasks, and changes in program funding.

Technical management and cost reviews of subcontractors wiil be used to ascertain any lack of performance at this ievel or any potential project delays. Weekly meetings with functional managers involved in the program will be used to elucidate any cielays in program activities being conducted or technically managed by these individuals. Executive control Meetings, held in accordance with established Rockwell policies, will be used to integrate the overall progress in the ghlp effort and measure overall performance. A monthly meeting will be held with DOE to. report on the overall work and to assess performance to date.

The performance control system is intended to provide a major level of visibility to DOE for overview of the program and assurance that, within the Rockwell BWIP, management of detailed costs, schedules, and performance is in place.

\section{SCHEDULE CONTROL}

Schedules will be controlled in accordance with established procedures. Program Business Management provides scheduling support to the program at a11 levels of the schedule hierarchy. The Program Pianning, Scheduling and Control Department is responsible for the coordinated development, integration, maintenance, and status reporting of the programmatic plans and schedules. Milestones on the schedules are controlied via a Schedule Control Sheet (Figure 7.4). 
RHO-CD-132. REV 5

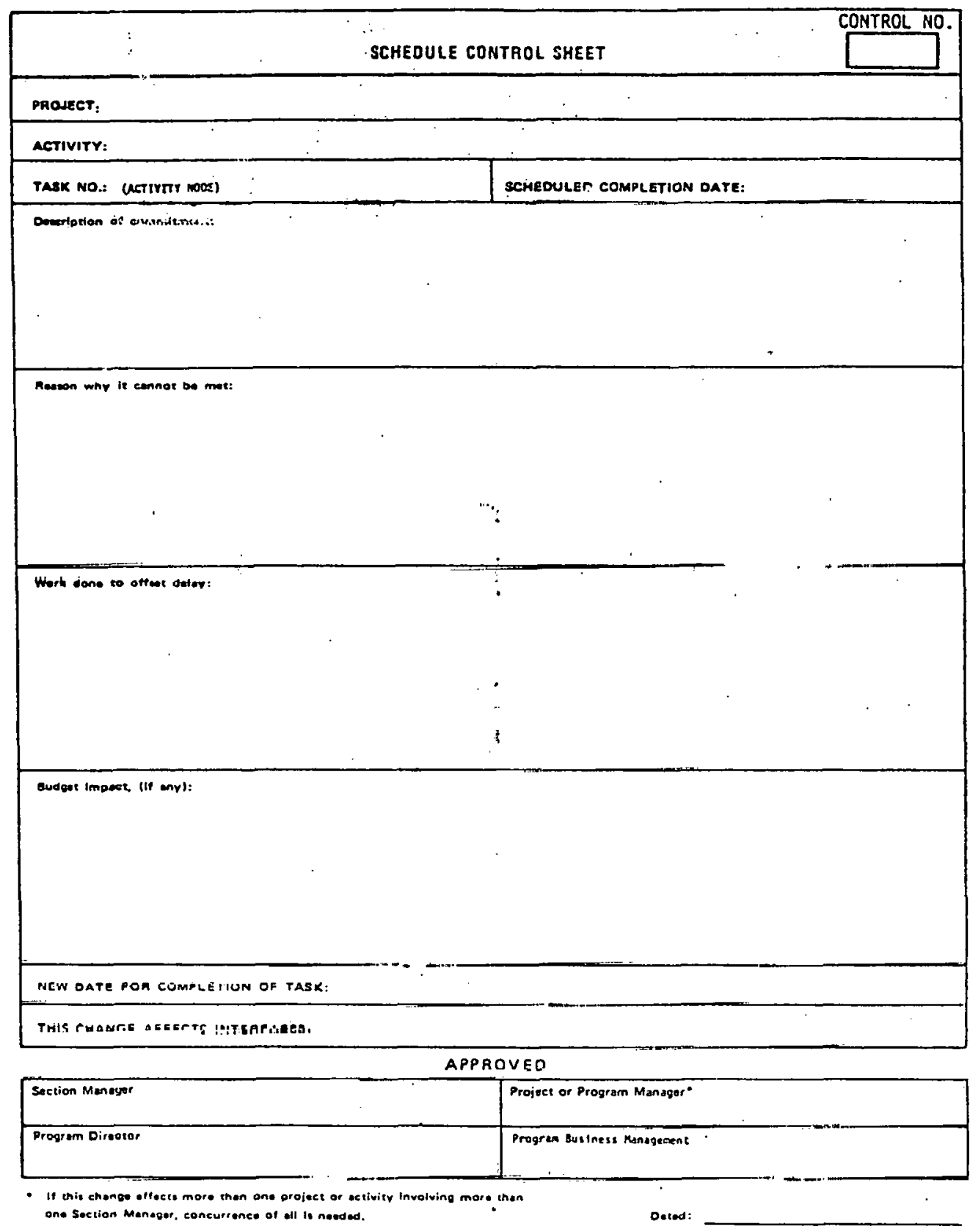

FIGURE 7.4. Schedule Control Sheet-Basalt Waste Isolation Project. 


\section{DISTRIBUTION}

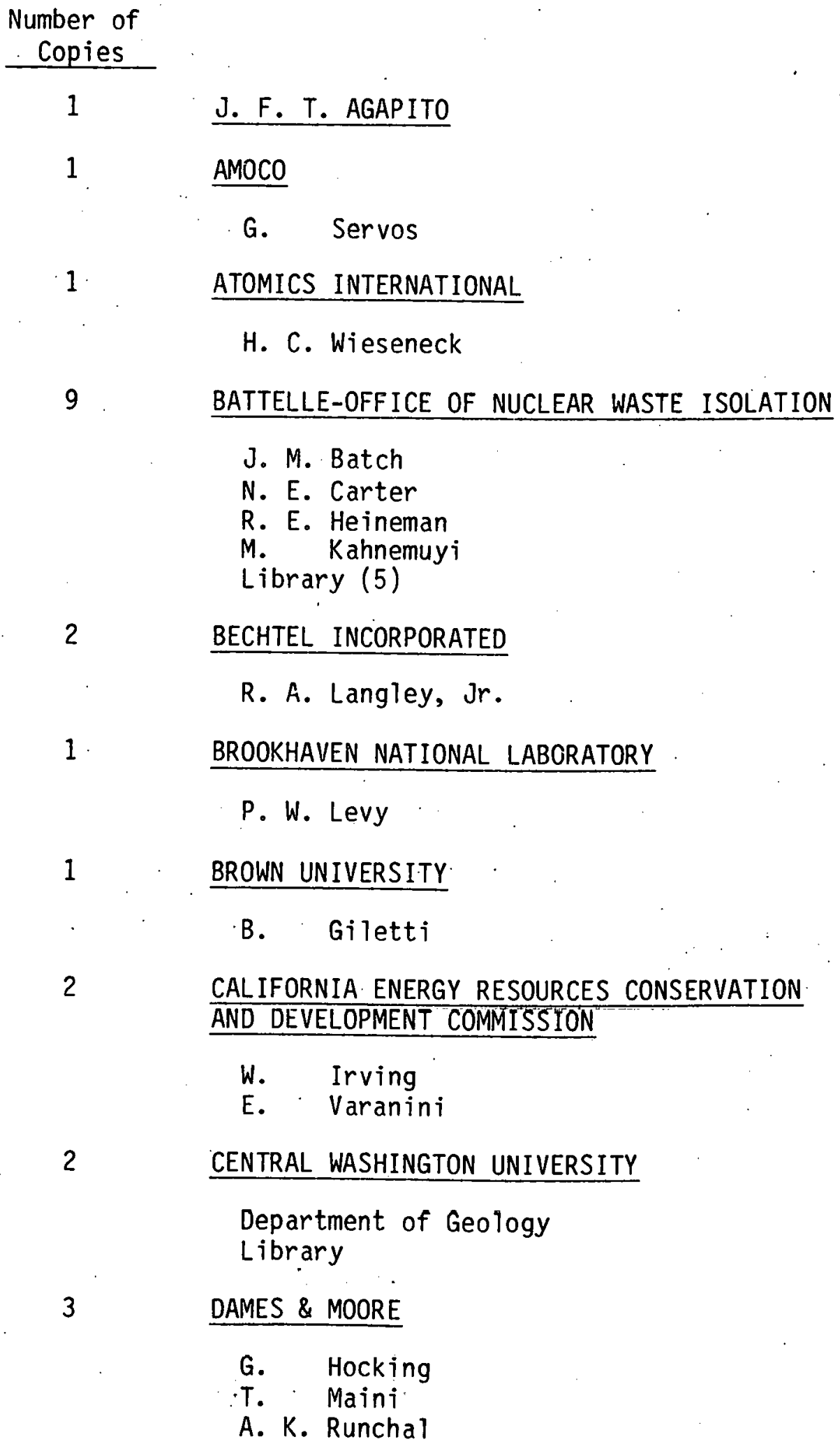

2

CENTRAL WASHINGTON UNIVERSITY

Department of Geology Library

DAMES \& MOORE

G. Hocking

T. Maini

A. K. Runchal 
Number of Copies

1

COLORADO SCHOOL OF MINES

F. D. Wang

1

2

Department of Geology

l.ibrary

2

FOUNDATION SCIENC.ES, INC.

D. J. Dodds

Library

1

HARVARD UNIVERSITY

R. Siever

IDAHO BUREAU OF MINES AND GEOLOGY

M. M. Miller

Library

1

KANSAS STATE GEOLOGICAL SURVEY

w. W. Hambleton

LAWRENCE BERKELEY LABORATORY

L. V. Benson

P. A. Witherspoon

1

LAWRENCE LIVERMORE LABORATORY

L. Ramspott

2

LOS ALAMOS SCIENTIF IC LÄBORATORY

M. L. Wheeler

K. Wolfsberg

LOS ALAMOS TECHNICAL ASSOCTATES 
Number of

Copies

3

18

NATIONAL ACADEMY OF SCIENCES
W. E. Berg
D. Daley
S. Stuen

NATIONAL ACADEMY OF SCIENCES -

COMMITTEE ON RADIOACTIVE WASTE MANAGEMENT
M. Baram
S. N. Davis
E. L. Draper
P. W. Durbin
J. T. Edsall
M. Eisenbud
J. A. Fay
J. C. Frye
E. F. Gloyna
H. L. James
R. E. Kasperson
K. B. Krauskopf
T. R. Laporte
C. Mawson
F. L. Parker
T. Pigford
R. Roy
E. Wenk, Jr.

OREGON STATE DEPARTMENT OF GEOLOGY AND MINERAL INDUSTRIES

J. D. Beaulieu

OREGON STATE UNIVERSITY

Department of Geology

Library

PACIFIC NORTHWEST LABORATORY

J. R. Eliason

A. M. Platt (2)

R. W. Wallace

Library

1

THE PENNSYLVANIA STATE UNIVERSITY

B. E. Scheetz 
Number of Copies

1

PRINCETON UNIVERSITY

G. Pinder

1

8

S. B. RUBIN

SANDIA LABORATORIES

E. H. Beckner

F. A. Donath

0 . E. Jones

R. C. Linronin

R. W. Lynch

A. E. Stephenson

L. D. Tyler

W. D. Weart

SEISMOGRAPH SERVICE CORPORATION

Library

1

SENTURION SCIENCES, INC.

Library

1

STANFORD UNIVERSITY

I. Remson

1

SWEDISH NUCLEAR FUEL SUPPLY COMPANY (KBS)

L. D. N1115üi

1

W. K. SUMMERS AND ASSOCIATES

STATE OF IDAHO GOVERNOR'S OFFICE

C. Jones

1

STATE OF OREGON GOVERNOR 'S OFF ICE

K. Woods

1

STATE OF WASHINGTON GOVERNOR'S OFFICE

D. Jankins

1

Library 
Number of Copies

TEXAS A \& M UNIVERSITY

J. Handin

1

UNION OF CONCERNED SCIENTISTS

R. Lipschutz

1

UNC NUCLEAR INDUSTRIES

G. 0. Amy

4

U. S. ARMY CORPS OF ENGINEERS

Seatt Te District Geologist

Seattle District Librarian

Walla Walla District Geologist

Walla Walla District Librarian

1

U. S. BUREAU OF MINES

J. W. Corwine

U. S. BUREAU OF RECLAMATION

D. Newmann

U. S. DEPARTMENT OF ENERGY-ALBUQUERQUE OPERATIONS OFFICE

D. T. Schueler

1

U. S. DEPARTMENT OF ENERGY-COLUMBUS PROGRAM OFFICE

J. 0. Neff

60

U. S. DEPARTMENT OF ENERGY-HEADQUARTERS
R. H. Campbe 11
D. B. LeClaire
C. R. Cooley
M. W. Frei
S. Meyers
C. H. George
C. A. Heath (2)
R. G. Romatowski
R. Stein
D. L. Vieth (50)

2

U. S. DEPARTMENT OF ENERGY-NEVADA OPERATIONS OFFICE

D. G. Jackson

R. M. Nelson

1 U. S. DEPARTMENT OF ENERGY-OAK RIDGE OPERATIONS OFFICE

C. A. Keller 
Number of Copies

2

U. S. DEPARTMENT OF ENERGY-PUBLIC READING ROOMS

Richland, Washington

Seattle, Washington

11

U. S. DEPARTMENT OF ENERGY-RICHLAND OPERATIONS OFF ICE

L. J. Adams

J. C. Cummings

R. B. Goranson

A. G. Lassila

B. L. Nicoll

A. F. Pennington

D. J. Squires (5)

1

U. S. DEPARTMENT OF ENERGY-SAN FRANCISCO OPERATIONS OFFICE

L. Lanni

3 U. S. ENVIRONMENTAL PROTECTION AGENCY
R. Kaufman
G. L. Meyers
J. Sceva

7

U. S. GEOLOGICAL SURVEY

C. Collier

G. D. DeBuchananne

W. W. Dudley, Jr.

$R$. Schneider

P. R. Stevene

D. A. Swanson

W. S. Twenhofel

5

U. S. NUCLEAR REGULATORY COMMISSION

R. Boyle

J. 0. Bunting, Jr.

J. C. Malaro

J. B. Marlin

E. P. Rrgnier

2

UNIVERSITY OF IDAHO

Department of Geology

Library 


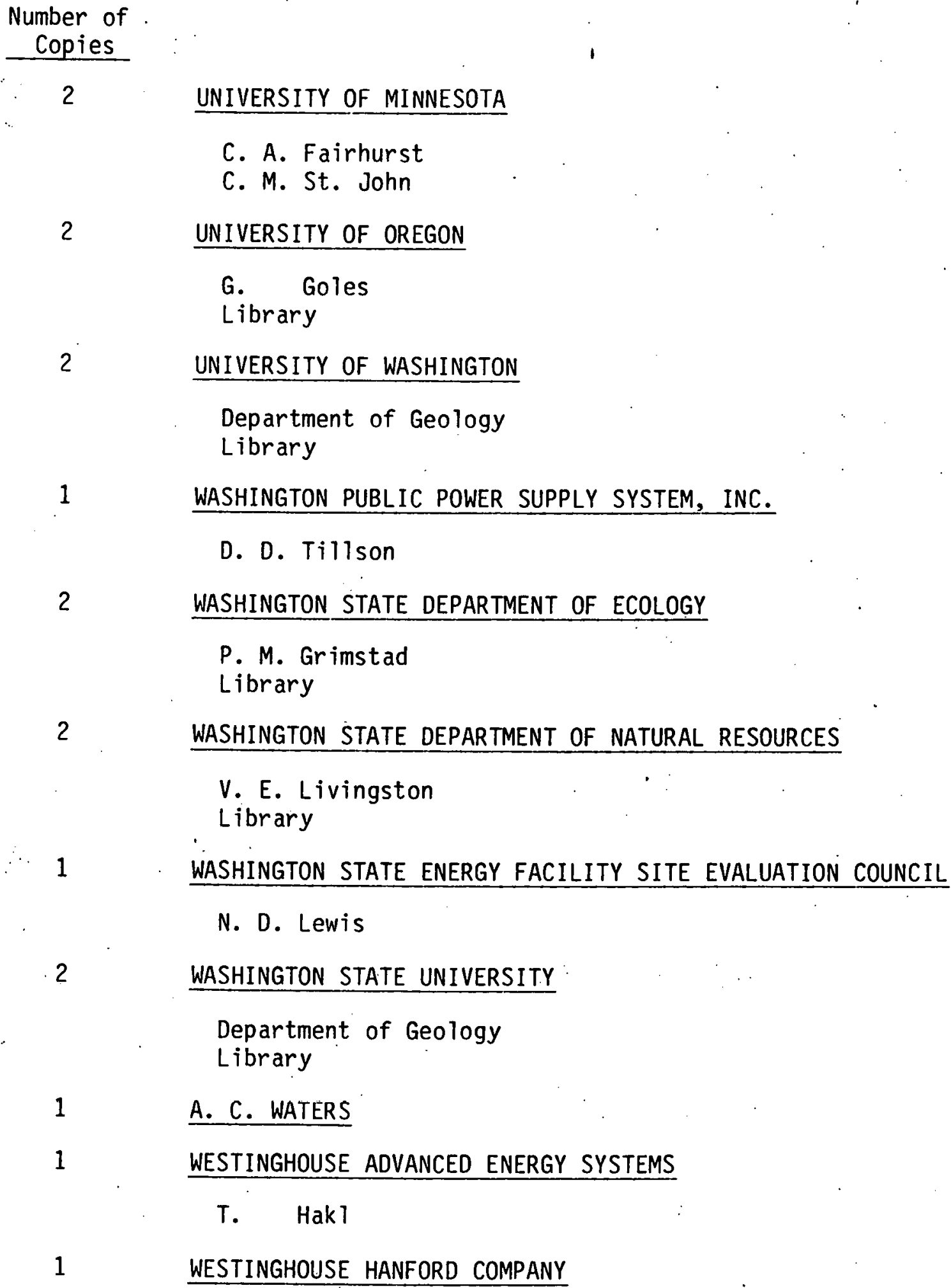

WESTINGHOUSE HANFORD COMPANY

A. G. Blasewitz 
RHO-CD-132 REV 5

Number of

Copies

WESTINGHOUSE WIPP PROJECT

R. C. Mairson

1

WOODWARD-CLYDE CONSULTANTS

Library

91

ROCKWELL HANFORD OPERATIONS
H. Babad
D. C. Rart.hnl nmew
M. Bellofatto
R. L. Biggerstaff
D. J. Brown
J. M. Carey
D. J. Cockeram
T. A. Curran
M. H. Curtis
R. A. Deju
H. B. Dietz
J. W. Donahue
R. A. Freeman
P. J. Fritch
R. E. Gephart
R. J. Gimera
G. L. Gurwell
R. D. Hammond
A. R. Hawk ins
K. H. Henry
G. S. Hunt
R. E. Isaacson
M. R. Kasper, Jr.
J. E. Kinzer
K. R. Kosorok

E. J. Kosiancic

A. D. Krug

W. J. Kurzeka

R. K. Ledgerwood

R. J. Mack

J. F. Marron

D. L. Martin

C. W. Myers

S. M. Price

R. Raphael

R. C. Roal

J. H. Roecker

D. B. Stephens

M. J. Smith

J. S. Sprouse

D. A. Turner

C. T. Webster

R. T. Wilde

L. Wilhermi

D. D. Wodrich

Basalt Waste Isolation

Project Library (50)

Document Control (4)

Records Retention Center (2) 